\title{
Geologic Framework for the National Assessment of Carbon Dioxide Storage Resources-Alaska North Slope and Kandik Basin, Alaska
}

By William H. Craddock, Marc L. Buursink, Jacob A. Covault, Sean T. Brennan, Colin A. Doolan, Ronald M. Drake II, Matthew D. Merrill, Tina L. Roberts-Ashby, Ernie R. Slucher, Peter D. Warwick, Madalyn S. Blondes, Philip A.

Freeman, Steven M. Cahan, Christina A. DeVera, and Celeste D. Lohr

Chapter I of

Geologic Framework for the National Assessment of Carbon Dioxide Storage Resources

Edited by Peter D. Warwick and Margo D. Corum

Open-File Report 2012-1024-I

U.S. Department of the Interior

U.S. Geological Survey 


\section{U.S. Department of the Interior \\ SALLY JEWELL, Secretary}

\section{U.S. Geological Survey \\ Suzette M. Kimball, Acting Director}

U.S. Geological Survey, Reston, Virginia: 2014

For product and ordering information:

World Wide Web: http://www.usgs.gov/pubprod

Telephone: 1-888-ASK-USGS

For more information on the USGS-the Federal source for science about the Earth,

its natural and living resources, natural hazards, and the environment:

World Wide Web: http://www.usgs.gov

Telephone: 1-888-ASK-USGS

Suggested citation:

Craddock, W.H., Buursink, M.L., Covault, J.A., Brennan, S.T., Doolan, C.A., Drake, R.M., II, Merrill, M.D., Roberts-Ashby, T.L., Slucher, E.R., Warwick, P.D., Blondes, M.S., Freeman, P.A., Cahan, S.M., DeVera, C.A., and Lohr, C.D., 2014, Geologic framework for the national assessment of carbon dioxide storage resources-Alaska North Slope and Kandik Basin, Alaska, chap. I of Warwick, P.D., and Corum, M.D., eds., Geologic framework for the national assessment of carbon dioxide storage resources: U.S. Geological Survey Open-File Report 2012-1024-I, 60 p., http://dx.doi.org/10.3133/ofr20121024l.

ISSN 2331-1258 (online)

Any use of trade, product, or firm names is for descriptive purposes only and does not imply endorsement by the U.S. Government.

Although this report is in the public domain, permission must be secured from the individual copyright owners to reproduce any copyrighted material contained within this report. 


\title{
Editors' Preface
}

\author{
By Peter D. Warwick and Margo D. Corum
}

The 2007 Energy Independence and Security Act (Public Law 110-140; U.S. Congress, 2007) directs the U.S. Geological Survey (USGS) to conduct a national assessment of potential geologic storage resources for carbon dioxide (CO2) and to consult with other Federal and State agencies to locate the pertinent geological data needed for the assessment. The geologic storage of $\mathrm{CO} 2$ is one possible way to mitigate its effects on climate change.

The methodology used by the USGS for the assessment was described by Brennan and others (2010), who revised the methodology by Burruss and others (2009) according to comments from peer reviewers, an external panel of experts, and members of the public. During the implementation phase of the assessment (from 2010 to 2012), several practical steps were added to the assessment methodology of Brennan and others (2010). The details of the methodology used in the assessment are described in Blondes and others (2013). The assessment methodology is non-economic and is intended to be used at regional to sub-basinal scales.

The operational unit of the assessment is a storage assessment unit (SAU), which is composed of a porous storage formation with fluid flow and an overlying fine-grained sealing unit. Assessments are conducted at the SAU level and are aggregated to basinal and regional results. SAUs have a minimum depth of 3,000 feet (ft), which ensures that the $\mathrm{CO} 2$ is in a supercritical state, and thus occupies less pore

space than a gas. Standard SAUs have a maximum depth of 13,000 $\mathrm{ft}$ below the surface, a depth accessible with average injection pipeline pressures (Burruss and others, 2009; Brennan and others, 2010; Blondes and others, 2013). Where geologic conditions favor $\mathrm{CO} 2$ storage below $13,000 \mathrm{ft}$, an additional deep SAU is assessed.

The assessments are also constrained by the occurrence of relatively fresh formation water; any formation water having a salinity less than 10,000 parts per million (ppm, which is equivalent to milligrams per liter, $\mathrm{mg} / \mathrm{L}$ ) total dissolved solids (TDS), regardless of depth, has the potential to be used as a potable water supply (U.S. Environmental Protection Agency, 2009). The U.S. Environmental Protection Agency (EPA) (2010) defines the lower limit of 10,000 ppm (mg/L) TDS for injection of CO2. Therefore, the potential storage resources for $\mathrm{CO} 2$ in formations where formation waters have salinities less than 10,000 ppm (mg/L) TDS are not assessed (Brennan and others, 2010; Blondes and others, 2013).

This report series contains a geologic description of each SAU identified within each report's assessed basins and focuses on particular characteristics specified in the methodology that influence the potential $\mathrm{CO} 2$ storage resource. The geologic framework information contained in these reports was used to calculate a statistical Monte Carlo-based distribution of potential storage space in the various SAUs following Brennan and others (2010) and Blondes and others (2013). Assessment data, results, and summary can be found in the U.S. Geological Survey Geologic Carbon Dioxide Storage Resources Assessment Team's (2013a,b,c) reports. Figures in this report series show SAU boundaries and cell maps of well penetrations through the sealing unit into the top of the storage formation. Wells sharing the same well borehole are treated as a single penetration. Cell maps show the number of penetrating wells within one square mile and are derived from interpretations of incompletely attributed well data (IHS Energy Group, 2011; and other data as available), a digital compilation that is known not to include all drilling. The USGS does not expect to know the location of all wells and cannot guarantee the amount of drilling through specific formations in any given cell shown on cell maps. 


\section{References Cited}

Blondes, M.S., Brennan, S.T., Merrill, M.D., Buursink, M.L., Warwick, P.D., Cahan, S.M., Cook, T.A., Corum, M.D., Craddock, W.H., DeVera, C.A., Drake, R.M., Drew, L.J., Freeman, P.A., Lohr, C.D., Olea, R.A., Roberts-Ashby, T.L., Slucher, E.R., and Varela, B.A., 2013, National assessment of geologic carbon dioxide storage resources-Methodology implementation: U.S. Geological Survey Open-File Report 2013-1055, 26 p., at http://pubs.usgs.gov/of/2013/1055/.

Brennan, S.T., Burruss, R.C., Merrill, M.D., Freeman, P.A., and Ruppert, L.F., 2010, A probabilistic assessment methodology for the evaluation of geologic carbon dioxide storage: U.S. Geological Survey Open-File Report 2010-1127, 31 p., accessed March 22, 2011, at http://pubs.usgs.gov/of/2010/1127/.

Burruss, R.C., Brennan, S.T., Freeman, P.A., Merrill, M.D., Ruppert, L.F., Becker, M.F., Herkelrath, W.N., Kharaka, Y.K., Neuzil, C.E., Swanson, S.M., Cook, T.A., Klett, T.R., Nelson, P.H., and Schenk, C.J., 2009, Development of a probabilistic assessment methodology for evaluation of carbon dioxide storage: U.S. Geological Survey Open-File Report 2009-1035, 81 p., accessed March 22, 2011, at http://pubs.usgs.gov/of/2009/1035/.

IHS Energy Group, 2011, ENERDEQ U.S. well data: IHS Energy Group, online database available from IHS Energy Group, 15 Inverness Way East, D205, Englewood, CO 80112, U.S.A., accessed January 20, 2011.

U.S. Congress, 2007, Energy Independence and Security Act of 2007-Public Law 110-140: U.S. Government Printing Office, 311 p., accessed October 30, 2012, at http://frwebgate.access.gpo.gov/cgibin/getdoc.cgi? dbname=110_cong_public_laws\&docid=f:publ140.110.pdf.

U.S. Environmental Protection Agency, 2009, Safe Drinking Water Act (SDWA): Washington, D.C., U.S. Environmental Protection Agency Web site, accessed January 14, 2009, at http://www.epa.gov/ogwdw/sdwa/index.html.

U.S. Environmental Protection Agency, 2010, Final rule for Federal requirements under the underground injection control (UIC) program for carbon dioxide (CO2) geologic sequestration (GS) wells: Washington, D.C., U.S. Environmental Protection Agency Web site, accessed October 15, 2012, at http://water.epa.gov/type/groundwater/uic/class6/gsregulations.cfm.

U.S. Geological Survey Geologic Carbon Dioxide Storage Resources Assessment Team, 2013a, National Assessment of Geologic Carbon Dioxide Storage Resources-Summary (ver. 1.1, September 2013): U.S. Geological Survey Fact Sheet 2013-3020, 6 p. (Supersedes ver. 1.0 released June 26, 2013.), at http://pubs.usgs.gov/fs/2013/3020/.

U.S. Geological Survey Geologic Carbon Dioxide Storage Resources Assessment Team, 2013b, National assessment of geologic carbon dioxide storage resources_-Data (ver. 1.1, September 2013): U.S. Geological Survey Data Series 774, 13 p., plus 2 appendixes and 2 large tables in separate files (Supersedes ver. 1.0 released June 26, 2013.), at http://pubs.usgs.gov/ds/774/.

U.S. Geological Survey Geologic Carbon Dioxide Storage Resources Assessment Team, 2013c, National assessment of geologic carbon dioxide storage resources-Results (ver. 1.1, September 2013): U.S. Geological Survey Circular 1386, 41 p. (Supersedes ver. 1.0 released June 26, 2013.), at http://pubs.usgs.gov/circ/1386/. 


\section{Contents}

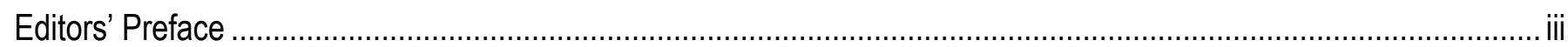

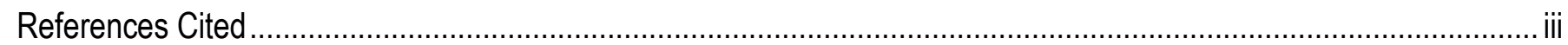

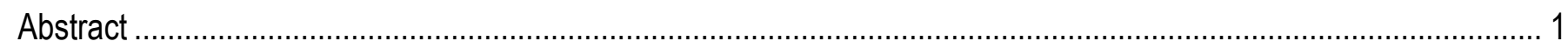

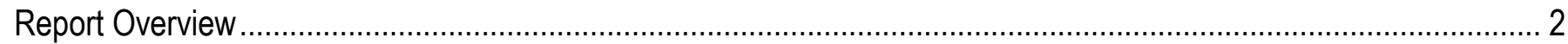

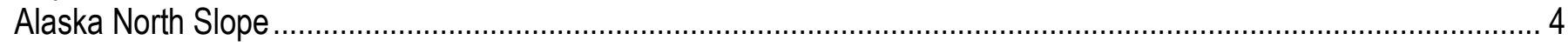

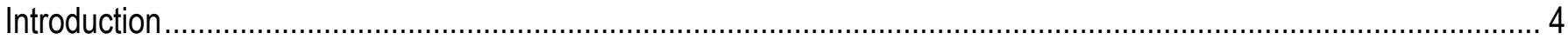

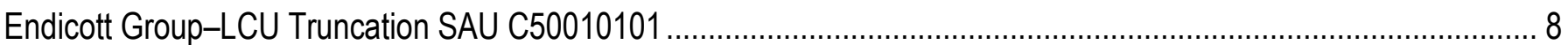

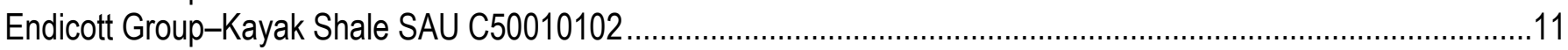

Lower Ellesmerian SAU C50010103 and Lower Ellesmerian Deep SAU C50010104 ...........................................13

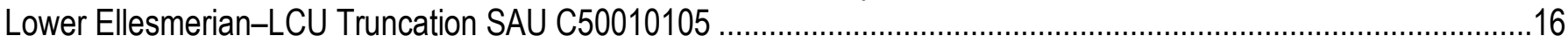

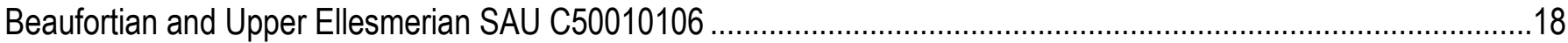

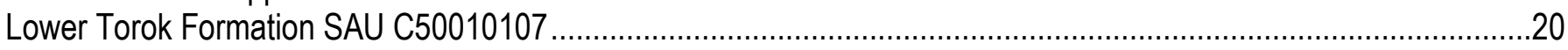

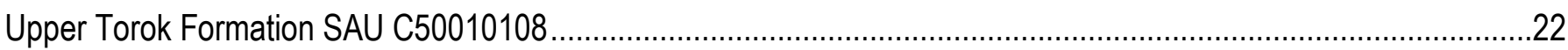

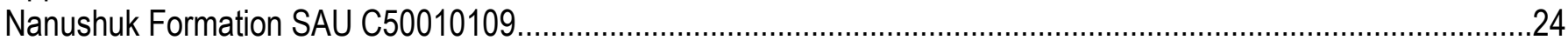

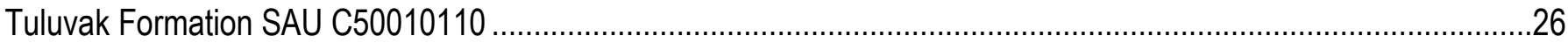

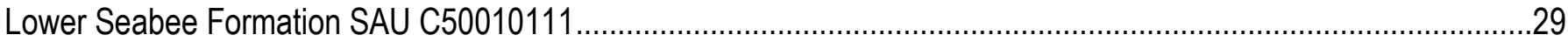

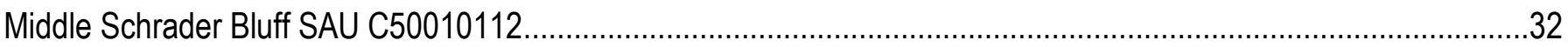

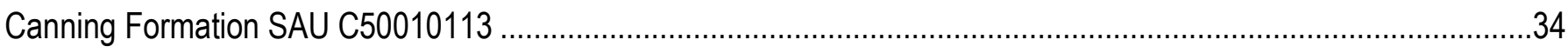

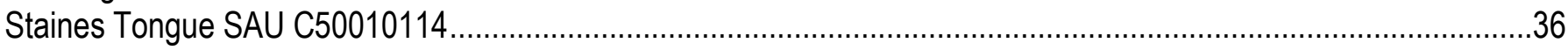

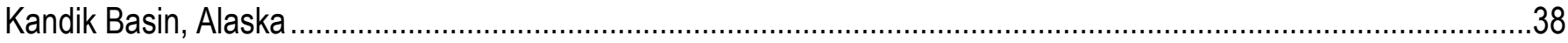

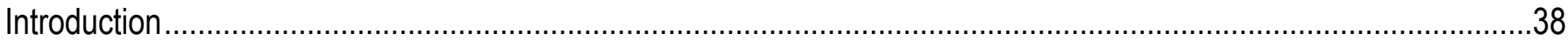

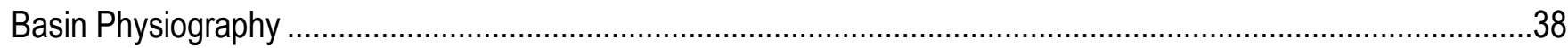

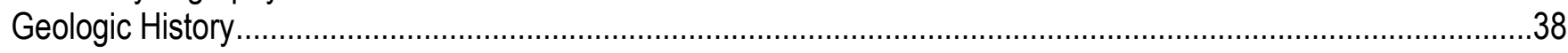

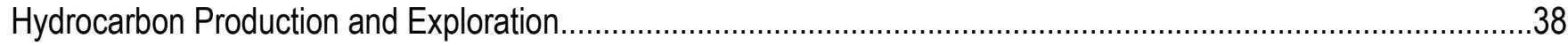

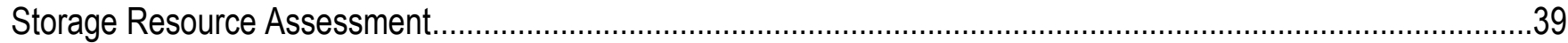

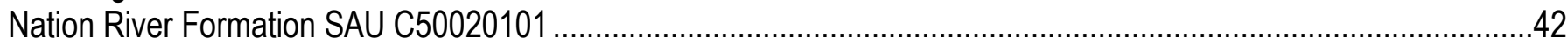

Step Conglomerate and Tahkandit Limestone SAU C50020102 ….....................................................................4

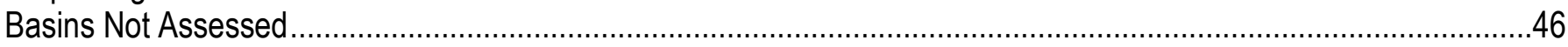

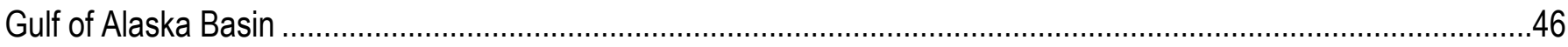

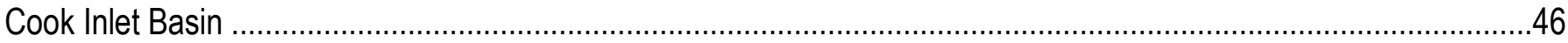

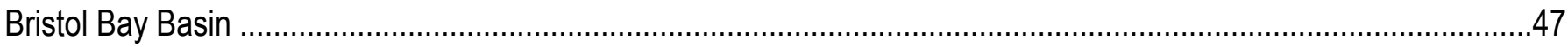

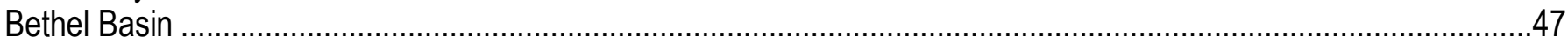

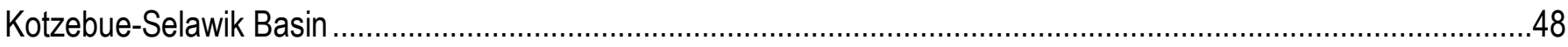

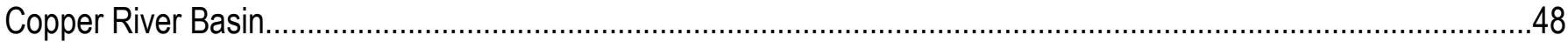

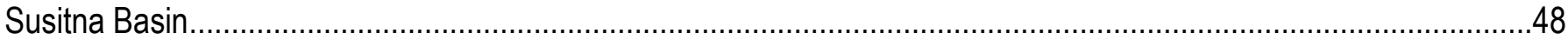

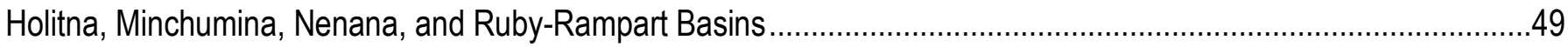

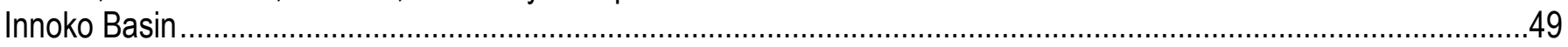

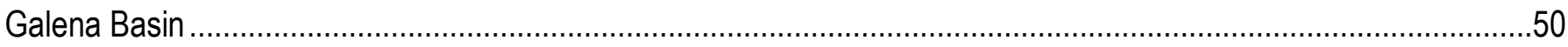

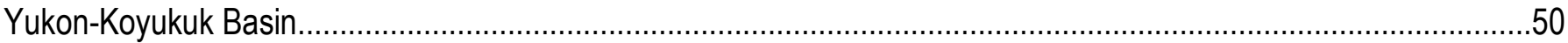

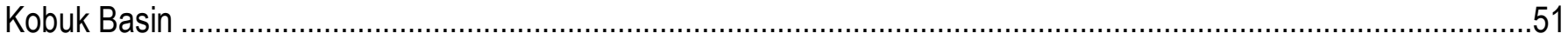

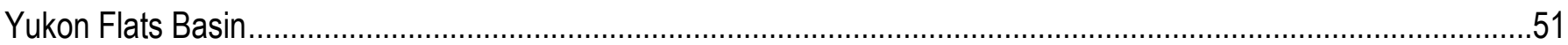

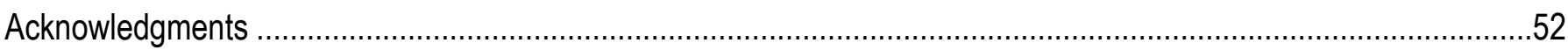

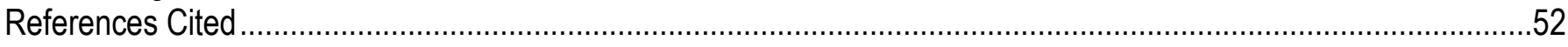




\section{Figures}

Figure 1. Map of study areas in Alaska that were evaluated for geologic $\mathrm{CO}_{2}$ storage potential ......................... 3

Figure 2. Map of the Alaska North Slope study area, including major structural features .................................. 6

Figure 3. Generalized stratigraphic column of geologic units of the Alaska North Slope study area...................... 7

Figure 4. Map of the U.S. Geological Survey storage assessment unit (SAU) boundary for the Endicott

Group-LCU Truncation SAU (C50010101) in the Alaska North Slope study area.................................................. 10

Figure 5. Map of the U.S. Geological Survey storage assessment unit (SAU) boundary for the Endicott Group-Kayak Shale SAU (C50010102) in the Alaska North Slope study area ................................................... 12

Figure 6. Map of the U.S. Geological Survey storage assessment unit (SAU) boundary for the Lower Ellesmerian SAU (C50010103) and the Lower Ellesmerian Deep SAU (C50010104) in the Alaska North Slope study area.

Figure 7. Map of the U.S. Geological Survey storage assessment unit (SAU) boundary for the Lower Ellesmerian-LCU SAU (C50010105) in the Alaska North Slope study area....

Figure 8. Map of the U.S. Geological Survey storage assessment unit (SAU) boundary for the Beaufortian and Upper Ellesmerian SAU (C50010106) in the Alaska North Slope study area ....

Figure 9. Map of the U.S. Geological Survey storage assessment unit (SAU) boundary for the Lower Torok Formation SAU (C50010107) in the Alaska North Slope study area .

Figure 10. Map of the U.S. Geological Survey storage assessment unit (SAU) boundary for the Upper Torok Formation SAU (C50010108) in the Alaska North Slope study area ................................................................. 23

Figure 11. Map of the U.S. Geological Survey storage assessment unit (SAU) boundary for the Nanushuk Formation SAU (C50010109) in the Alaska North Slope study area ............................................................... 25

Figure 12. Map of the U.S. Geological Survey storage assessment unit (SAU) boundary for the Tuluvak Formation SAU (C50010110) in the Alaska North Slope study area

Figure 13. Map of the U.S. Geological Survey storage assessment unit (SAU) boundary for the Lower Seabee Formation SAU (C50010111) in the Alaska North Slope study area ....

Figure 14. Map of the U.S. Geological Survey storage assessment unit (SAU) boundary for the Middle Schrader Bluff SAU (C50010112) in the Alaska North Slope study area.....

Figure 15. Map of the U.S. Geological Survey storage assessment unit (SAU) boundary for the Canning Formation SAU (C50010113) in the Alaska North Slope study area 35

Figure 16. Map of the U.S. Geological Survey storage assessment unit (SAU) boundary for the Staines Tongue SAU (C50010114) in the Alaska North Slope study area

Figure 17. Map of the Kandik Basin, Alaska, study area. Included are major structural features and basin locations

Figure 18. Generalized stratigraphic column of geologic units in the Kandik Basin, Alaska, study area......

Figure 19. Map of the U.S. Geological Survey storage assessment unit (SAU) boundary for the Nation River Formation SAU (C50020101) in the Kandik Basin, Alaska, study area .

Figure 20. Map of the U.S. Geological Survey storage assessment unit (SAU) boundary for the Step Conglomerate and Tahkandit Limestone SAU (C50020102) in the Kandik Basin, Alaska, study area 


\section{Conversion Factors}

\begin{tabular}{|c|c|c|}
\hline Multiply & By & To obtain \\
\hline \multicolumn{3}{|c|}{ Length } \\
\hline inch (in.) & 2.54 & centimeter $(\mathrm{cm})$ \\
\hline foot $(\mathrm{ft})$ & 0.3048 & meter $(\mathrm{m})$ \\
\hline mile (mi) & 1.609 & kilometer $(\mathrm{km})$ \\
\hline \multicolumn{3}{|c|}{ Area } \\
\hline acre & 0.4047 & hectare (ha) \\
\hline acre & 0.004047 & square kilometer $\left(\mathrm{km}^{2}\right)$ \\
\hline \multicolumn{3}{|c|}{ Volume } \\
\hline barrel (bbl), (petroleum, 1 barrel = 42 gal) & 0.1590 & cubic meter $\left(\mathrm{m}^{3}\right)$ \\
\hline cubic foot $\left(\mathrm{ft}^{3}\right)$ & 0.02832 & cubic meter $\left(\mathrm{m}^{3}\right)$ \\
\hline 1,000 cubic feet $(\mathrm{MCF})$ & 28.32 & cubic meter $\left(\mathrm{m}^{3}\right)$ \\
\hline liter (L) & 0.2642 & gallon (gal) \\
\hline
\end{tabular}

\section{Abbreviations}

$\begin{array}{ll}\text { ANWR } & \text { Arctic National Wildlife Refuge } \\ \text { LCU } & \text { Lower Cretaceous unconformity } \\ \text { mD } & \text { millidarcys } \\ \text { mg/L } & \text { milligrams per liter } \\ \text { MMbbl } & \text { million petroleum barrels } \\ \text { NOGA } & \text { National Oil and Gas Assessment } \\ \text { NPRA } & \text { National Petroleum Reserve-Alaska } \\ \text { SAU } & \text { storage assessment unit } \\ \text { TCFG } & \text { trillion cubic feet of gas } \\ \text { TDS } & \text { total dissolved solids } \\ \text { USDW } & \text { underground source of drinking water } \\ \text { USGS } & \text { U.S. Geological Survey }\end{array}$




\title{
Geologic Framework for the National Assessment of Carbon Dioxide Storage Resources-Alaska North Slope and Kandik Basin, Alaska
}

\author{
By William H. Craddock, Marc L. Buursink, Jacob A. Covault, Sean T. Brennan, Colin A. Doolan, Ronald M. Drake \\ II, Matthew D. Merrill, Tina L. Roberts-Ashby, Ernie R. Slucher, Peter D. Warwick, Madalyn S. Blondes, \\ Philip A. Freeman, Steven M. Cahan, Christina A. DeVera, and Celeste D. Lohr
}

\begin{abstract}
This report presents fourteen storage assessment units (SAUs) from the Alaska North Slope and two SAUs from the Kandik Basin of Alaska. The Alaska North Slope is a broad, north-dipping coastal plain that is underlain by a thick succession of sedimentary rocks that accumulated steadily throughout much of the Phanerozoic during three major tectonic sequences: the Mississippian through Triassic Ellesmerian sequence, the Jurassic through Lower Cretaceous Beaufortian sequence, and the Cretaceous and Tertiary Brookian sequence. Stratigraphic packages associated with all three of these tectonic sequences are suited to geologic carbon dioxide $\left(\mathrm{CO}_{2}\right)$ sequestration. The lower part of the Ellesmerian sequence contains five potential SAUs, two of which have reservoirs within the Endicott Group and three of which have reservoirs within the Lisburne Group. Another potential SAU has sandstone-prone reservoir units interbedded with the upper part of the Ellesmerian Shublik Formation and the Beaufortian Kingak Shale. The Brookian sequence contains eight potential SAUs that have reservoirs that are defined by the various Cretaceous and Tertiary deltaic topset strata of the Colville foreland basin as well as associated slope aprons and submarine turbidite fan complexes.

In east-central Alaska, Kandik Basin is an extension of cratonic North America and straddles the border between Alaska and Canada. The basin contains a section of Neoproterozoic to Mesozoic rocks, which have been multiply deformed during the Phanerozoic. Paleozoic strata within the basin appear to be suited to geologic $\mathrm{CO}_{2}$ sequestration. We defined two SAUs within this interval, which are the Upper Devonian and Mississippian Nation River Formation SAU and the Lower Permian to Lower Cretaceous Step Conglomerate and Tahkandit Limestone SAU.

For each SAU in both of the basins, we discuss the areal distribution of suitable $\mathrm{CO}_{2}$ sequestration reservoir rock. We also characterize the overlying sealing unit and describe the geologic characteristics that influence the potential $\mathrm{CO}_{2}$ storage volume and reservoir performance. These characteristics include reservoir depth, gross thickness, net thickness, porosity, permeability, and groundwater salinity. Case-by-case strategies for estimating the pore volume existing within structurally and (or) stratigraphically closed traps are presented. Although assessment results are not contained in this report, the geologic information included herein was employed to calculate the potential storage volume in the various SAUs. Lastly, in this report, we present the rationale for not conducting assessment work in fifteen sedimentary basins distributed across the Alaskan interior and within Alaskan State waters.
\end{abstract}




\section{Report Overview}

The following sections describe the geologic parameters used to define the carbon dioxide $\left(\mathrm{CO}_{2}\right)$ storage assessment units (SAUs) in the Alaska North Slope in northern Alaska and the Kandik Basin of east-central Alaska (fig. 1) (see Burruss and others, 2009; Brennan and others, 2010; and Blondes and others, 2013). We characterize the stratigraphic character and distribution of each prospective storage unit. We briefly summarize the key information that provides the basis for calculating the capacity of each of the stratigraphic units for buoyant and residual $\mathrm{CO}_{2}$ storage (as described in Burruss and others, 2009; Brennan and others, 2010; Blondes and others, 2013) including reservoir area, thickness, and porosity. The regional sealing formation for each SAU is discussed. We also describe general reservoir characteristics for each unit with an emphasis on probable reservoir porosity and permeability. Due to the fact that the U.S. Environmental Protection Agency (2010) stipulates that aquifers must contain groundwater with a total dissolved solids (hereafter TDS) concentration $>10,000 \mathrm{mg} / \mathrm{L}$ in order to be used for $\mathrm{CO}_{2}$ storage, we present descriptions of regional trends in groundwater quality. We present brief case-by-case summaries of the methods used to estimate the pore volume enclosed within buoyant traps (analogous to structurally and [or] stratigraphically enclosed oil and gas traps) for each unit. The attributes described within each section will be used in accordance with the U.S. Geological Survey (USGS) carbon sequestration assessment methodology (Burruss and others, 2009; Brennen and others, 2010; Blondes and others, 2013) to calculate the available storage space for $\mathrm{CO}_{2}$ within the SAU. Finally, this report closes with a brief discussion of the rationale for not conducting assessment work within fifteen sedimentary basins distributed across the Alaskan interior and within Alaskan State waters (fig. 1). 


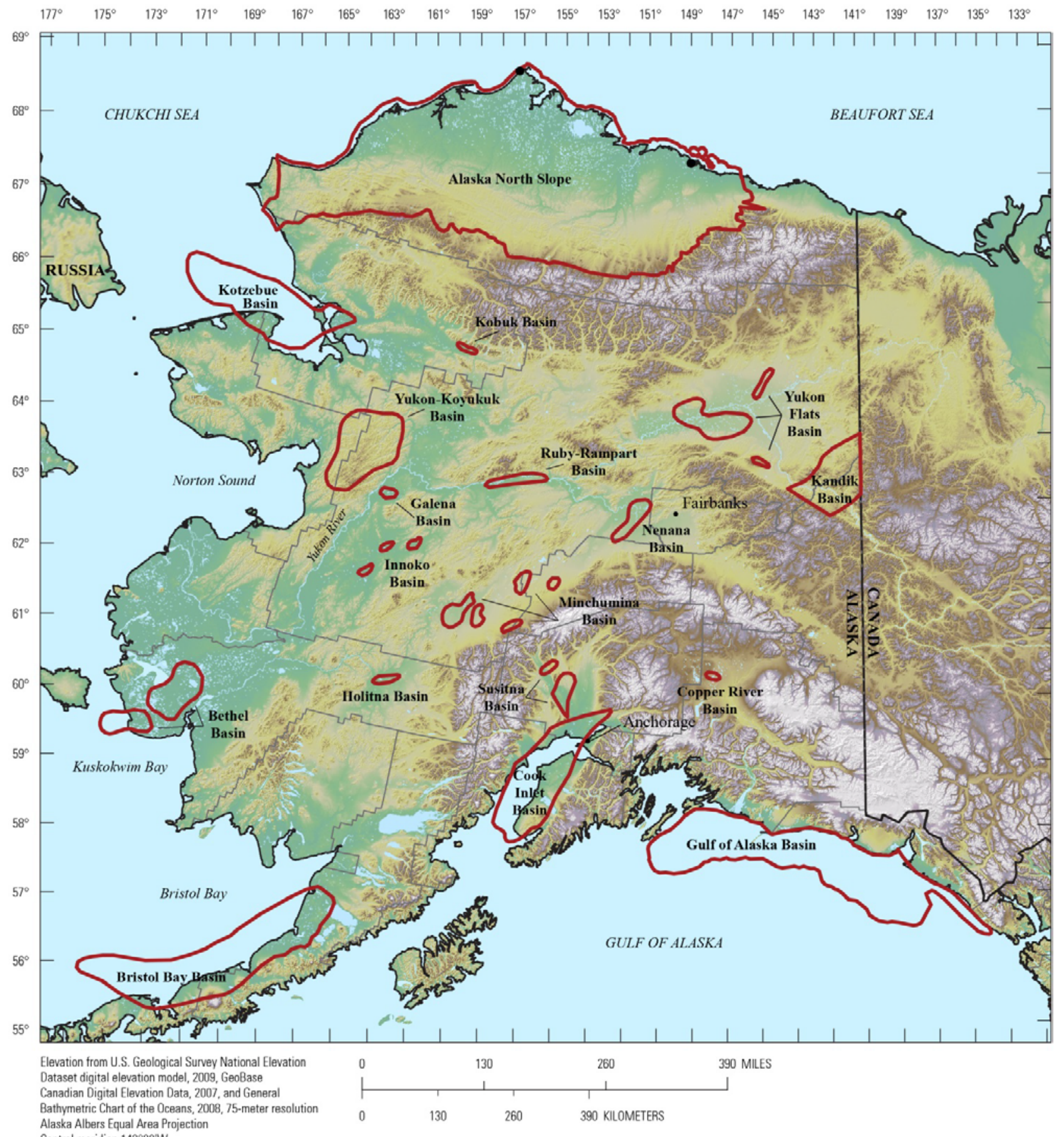

Alaska Albers Equal Area Projection

EXPLANATION
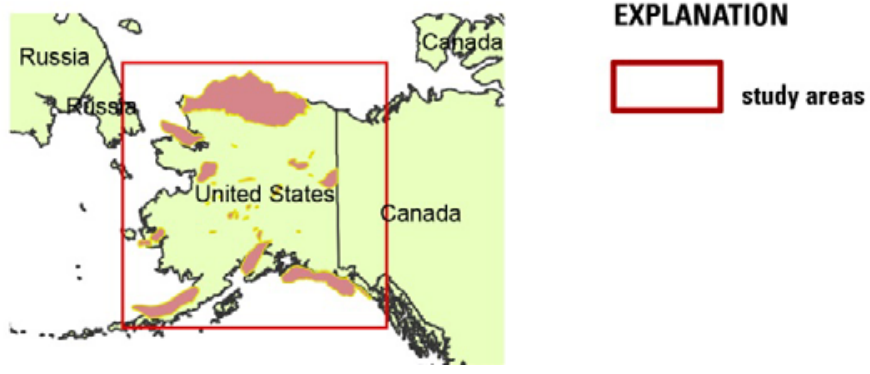

Figure 1. Map of study areas in Alaska that were evaluated for geologic carbon dioxide storage potential. The study areas are based on sedimentary basin boundaries adapted from Coleman and Cahan (2012). 


\section{Alaska North Slope}

By William H. Craddock, Jacob A. Covault, Sean T. Brennan, Colin Doolan A., Ronald M. Drake II, Matthew D. Merrill, Tina L. Roberts-Ashby, Ernie R. Slucher, Madalyn S. Blondes, Philip A. Freeman, Steven M. Cahan, Christina A. DeVera, and Celeste D. Lohr

\section{Introduction}

The Alaska North Slope is located north of the Brooks Range in northern Alaska and extends approximately 600 miles from the United States-Canada border westward to the Chukchi Sea and approximately 200 miles northward from the Brooks Range to the Beaufort Sea (fig. 2). The region exhibits a fairly continuous succession of Phanerozoic sedimentary rocks, which attain thicknesses in excess of several miles in major depocenters. The basin underlying the North Slope is developed atop the Arctic Alaska platform, which is a remnant of a late Paleozoic through early Mesozoic south-facing (present-day orientation) passive continental margin (Moore and others, 1994). The modern-day basin boundaries are generally defined by late Mesozoic and Cenozoic tectonic features. In this assessment, the northern basin boundary follows the Arctic coastline and generally follows the trend of the Barrow arch, an uplifted rift shoulder that formed during an episode of Jurassic to Early Cretaceous continental rifting (Grantz and May, 1983; Houseknecht and Bird, 2006). Along the southern basin margin, the Brooks Range developed as a result of collision of an island arc with the Arctic platform during the Late Jurassic and Early Cretaceous (Roeder and Mull, 1978; Wirth and others, 1993; Moore and others, 1994). Readers are directed to Hubbard and others (1987) and Moore and others (1994) for reviews of the geologic history of the region.

Sedimentary rocks within the Alaska North Slope have been grouped into three tectonostratigraphic sequences (fig. 2 of Lerand, 1973; Hubbard and others, 1987; Houseknecht and Bird, 2006). The Mississippian through Triassic Ellesmerian sequence is between 1.2 and 2.5 mi thick. The lower part of the sequence consists of nonmarine and marine siliciclastic strata that were shed from northern sediment source areas (present-day orientation, Moore and others, 1994). The strata were deposited along a south-facing (present-day orientation) continental margin, and they thicken into localized, normal-fault-bound structural lows. The upper part of the sequence consists of passive margin carbonate and generally fine-grained siliciclastic strata (Moore and others, 1994). The Jurassic and Lower Cretaceous Beaufortian sequence was deposited during rifting of the Arctic Alaskan platform along its northern (present-day orientation) margin and corresponding uplift of the Barrow arch. The sequence consists of fine-grained siliciclastic deposits that offlap the Barrow arch and thin to the south (Hubbard and others, 1987; Houseknecht and Bird, 2004). The Cretaceous and Tertiary Brookian sequence consists of up to six miles of lithic rich, siliciclastic clinothems that were shed from the Brooks Range as well as highlands to the west into a broad foreland basin during the Brookian orogeny (Molenaar, 1983; Mull and others, 2003; Houseknecht and others, 2009a,b). The Cretaceous and Tertiary foreland of the Brooks Range is called the Colville Basin, and we use this term in reference to the foreland phase of basin evolution throughout this report.

The Alaska North Slope is one of the most prolific petroleum producing provinces in the United States accounting for approximately 15,000 million barrels (MMbbl) of cumulative oil production as of December 2005, including approximately 12,000 MMbbl from the Prudhoe Bay field (fig. 2) (Alaska Department of Natural Resources, Division of Oil and Gas, 2006; Houseknecht and Bird, 2006). The majority of known petroleum accumulations are within structural traps or combination (structural and stratigraphic) traps adjacent to the Barrow arch (Houseknecht and Bird, 2006). Containment of hydrocarbon accumulations within these traps over geologic time suggests that regional caprocks are sufficiently impermeable for $\mathrm{CO}_{2}$ containment. Houseknecht and others (2010) employed a geology- 
based methodology to estimate mean volumes of $896 \mathrm{MMbbl}$ of oil and approximately 53 trillion cubic feet (tcf) of nonassociated natural gas in conventional, undiscovered accumulations within the National Petroleum Reserve-Alaska (NPRA) and adjacent State waters. Bird and others (2005) estimated a mean volume of 4,000 MMbbl of oil, $37.5 \mathrm{tcf}$ of natural gas, and $478 \mathrm{MMbbl}$ of natural gas liquids in the central North Slope region between NPRA and the Arctic National Wildlife Refuge (ANWR). Bird and Houseknecht (1998) estimated an additional mean volume of approximately 10,400 MMbbl of oil, 8.6 tcf of natural gas, and $320 \mathrm{MMbbl}$ of natural gas liquids in the 1002 Area of ANWR (see also, Houseknecht and Schenk, 1999). These various estimates were recently updated in a study spanning the entire U.S. Arctic Alaska Petroleum Province, including the North Slope adjacent continental shelves, in which the most likely undiscovered resource volumes were reported to be 30,000 MMbbl of oil, $41 \mathrm{tcf}$ of associated gas, and $181 \mathrm{tcf}$ of nonassociated gas with the vast majority of the potential being located north of the Brooks Range fold and thrust belt (Bird and Houseknecht, 2011; Houseknecht and others, 2012). The large historical production volumes and high potential for additional undiscovered petroleum accumulations imply that large pore volumes may be accessible for the purpose of geologic $\mathrm{CO}_{2}$ sequestration within produced fields and, possibly, uncharged traps. In fact, recent analysis of the $\mathrm{CO}_{2}$ sequestration capacity within 21 major oil fields on the North Slope indicates that up to 5 billion metric tons could be stored in these fields alone (Umekwe and others, 2012).

Reservoirs assessed for $\mathrm{CO}_{2}$ storage in the Alaska North Slope include (1) the Carboniferous Endicott Group of the lower Ellesmerian sequence, (2) composite reservoir units of the Carboniferous and Permian lower Ellesmerian sequence, (3) composite reservoir units of the Triassic, Jurassic, and Lower Cretaceous upper Ellesmerian and Beaufortian sequences, (4) the Cretaceous Torok Formation of the Brookian sequence, (5) the Cretaceous Nanushuk Formation of the Brookian sequence, (6) the Upper Cretaceous Tuluvak Formation of the Brookian sequence, (7) the Upper Cretaceous Seabee Formation of the Brookian sequence, (8) the Upper Cretaceous middle part of the Schrader Bluff Formation of the Brookian sequence, (9) the Upper Cretaceous and Paleogene Canning Formation of the Brookian sequence, and (10) the Paleogene Staines Tongue of the Sagavanirktok Formation of the Brookian sequence (fig. 3). 


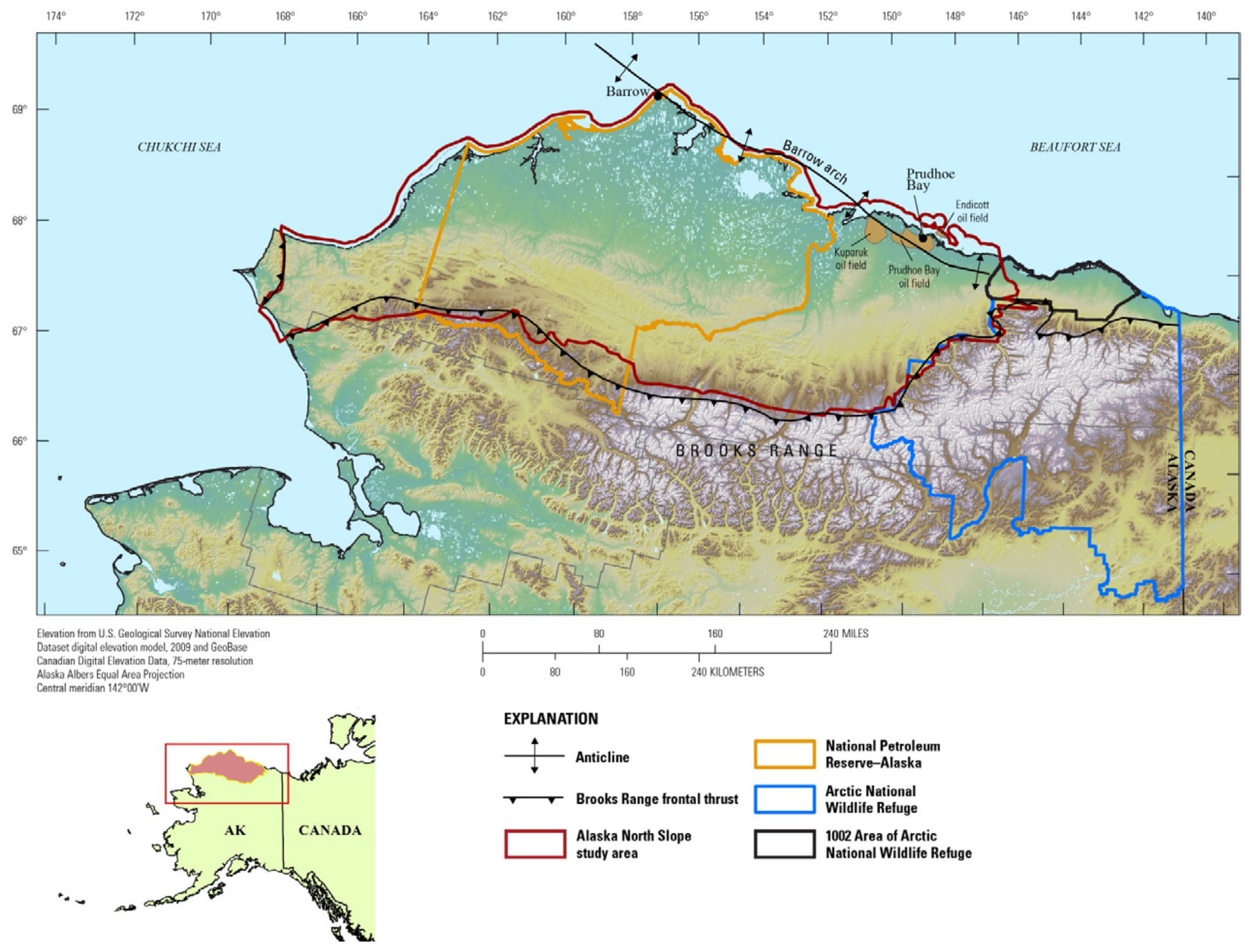

Figure 2. Map of the Alaska North Slope study area, including major structural features. The National Petroleum Reserve-Alaska and areas of the Arctic National Wildlife Refuge are outlined. Modified from Houseknecht and Bird (2006). 


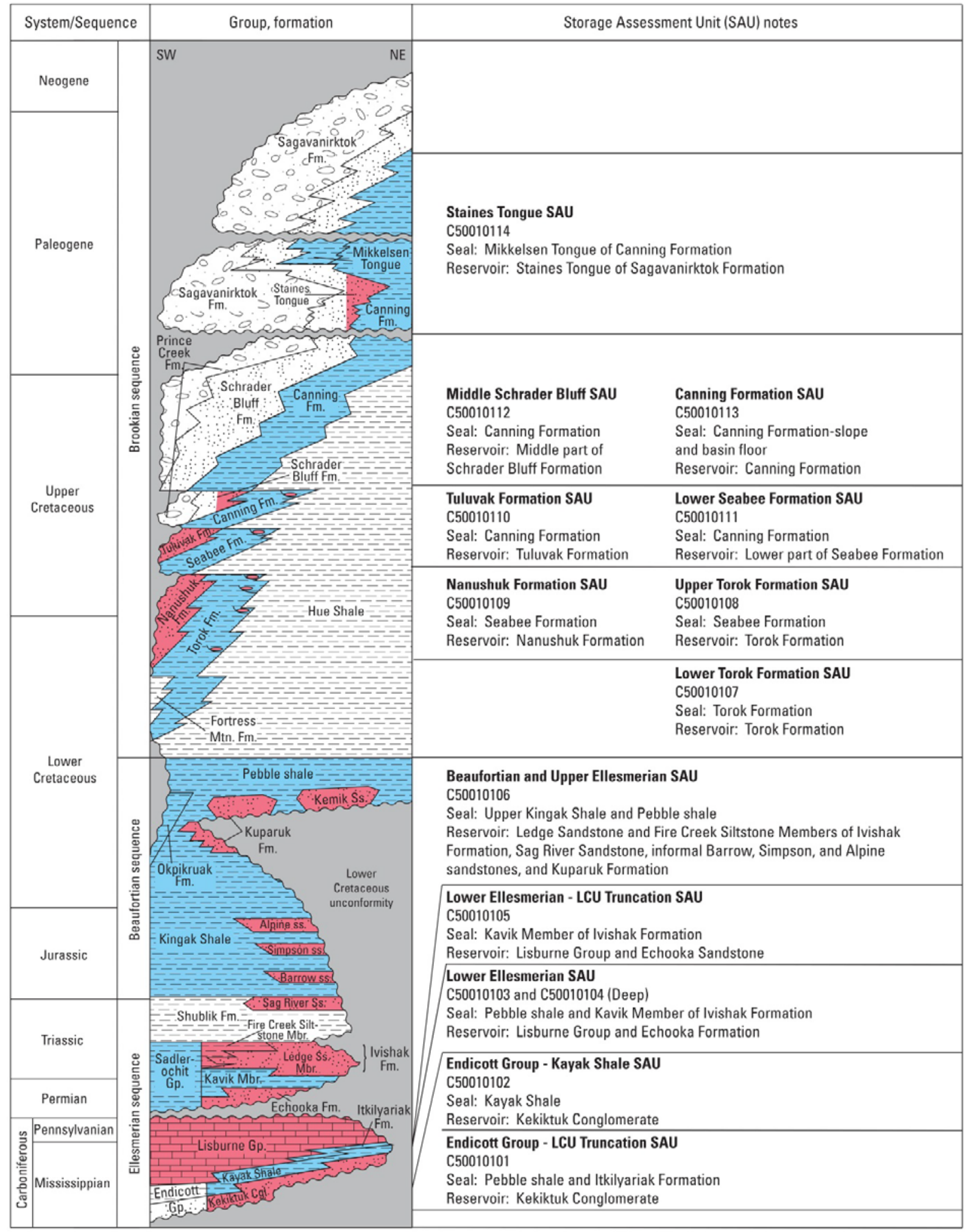

non-marine deposits

sandstone

$=-$ shale

limestone

Figure 3. Generalized stratigraphic column of geologic units of the Alaska North Slope study area. Storage assessment units (SAUs) consist of a reservoir or storage formation (red) and regional seal (blue). Wavy lines indicate unconformable contacts, and gray areas represent unconformities or hiatuses. In some cases, not all subdivisions of units are shown. Modified from Hubbard and others (1987), Moore and others (1994), Houseknecht and Bird (2004, 2006), and Decker (2007). 


\title{
Endicott Group-LCU Truncation SAU C50010101
}

\author{
By Ernie R. Slucher
}

The lower Carboniferous part of the Endicott Group is the basal lithostratigraphic unit in the Ellesmerian sequence on the Alaska North Slope (Hubbard and others, 1987). Throughout most of northern Alaska, the group overlies slightly metamorphosed pre-Carboniferous basement rock (Moore and others, 1994). The lower portion of Endicott was deposited mainly in fault-bound basins believed to have formed during regional extension along a south-facing (present-day orientation) continental margin (Hubbard and others, 1987; Wicks and other, 1991). Paleocurrent measurements, facies patterns, and other regional observations indicate that Endicott sediments were sourced from highlands occurring north of the current Beaufort Sea coastline (Hubbard and other, 1987; Wicks and others, 1991). Overall, the Endicott Group is a continental to marine transgressive sequence (Houseknecht and Bird, 2006). In the area of the assessment, the Endicott Group contains three formations, which are, in ascending stratigraphic order, the Kekiktuk Conglomerate, the Kayak Shale, and the Itkilyariak Formation (fig. 3) (Wicks and others, 1991; IHS Energy Group, 2010). The Kekiktuk Conglomerate is a braided to fluvial deposit consisting mostly of conglomerate and sandstone with lesser amounts of fine-grained siliciclastic rocks and coal beds. The Kekiktuk Conglomerate is thickest where deposited in extensional basins, but it thins and is locally absent where it onlapped structural highs present at the time of deposition (Wicks and others, 1991; see also, fig. 7 in Moore and others, 1994). The overlying Kayak Shale is a marine transgressive deposit that also thins and is absent over regional highs (Wicks and others, 1991). The Itkilyariak Formation is a marine sequence containing sandstone, shale, and some limestone. In general, the Endicott Group grades upward, and in places laterally, into the Lisburne Group (fig. 3).

As described above, Jurassic and earliest Cretaceous rifting along the northern margin of the Arctic Alaskan platform was accompanied by uplift of the Barrow arch along the rift margin (Hubbard and others, 1987). Erosion of this structural high resulted in the development of the regionally extensive Lower Cretaceous unconformity (hereafter referred to as LCU, see fig. 3), a feature that truncates a south-dipping package of pre-LCU rocks on the southern limb of the Barrow arch (Wicks and others, 1991; Houseknecht and Bird, 2006). Where the LCU truncated the Kekiktuk Conglomerate, secondary porosity and permeability developed (Wicks and others, 1991). The Kekiktuk Conglomerate is the potential storage reservoir for both Endicott Group assessments defined herein - it is the nature of the relationship between the sealing unit and reservoir that differentiates Endicott Group-LCU Truncation SAU (C50010101) and Endicott Group-Kayak Shale SAU (C50010102).

The Endicott Group-LCU Truncation SAU is an area where the Kekiktuk Conglomerate of the Endicott Group was truncated by erosion during the Early Cretaceous and now subcrops beneath the regional LCU of the Arctic North Slope (fig. 4). The overlying sealing units are the transgressive Lower Cretaceous pebble shale and the gamma-ray zone of the Hue Shale (also referred to as the highly radioactive zone; Wicks and others, 1991; Keller and others, 1999; Schenk and Houseknecht, 2008). Locally, Cretaceous incised valley-fill sandstone drapes the LCU (fig. 3) (Wicks and others, 1991; Schenk and Houseknecht, 2008), but these draping units are not included as part of the storage formation. Wicks and others (1991) noted that in the southern part of the Endicott petroleum field (which overlaps with the western portion of the SAU), the LCU truncation does not extend down section to the Kekiktuk Conglomerate, such that shale of the overlying Itkilyariak Formation acts as the top seal for the field. Such a relationship may extend along the entire southern portion of the SAU, but additional boundary refinement was not possible with available data. Areas of the western portion of the Endicott field that were identified as being overlain by the Kayak Shale were assigned to Endicott Group-Kayak Shale SAU (see below). 
The boundaries of Endicott-LCU Truncation SAU, which are defined by the trace of Endicott Group subcrop beneath the LCU, were delineated with data from Wicks and others (1991), Schenk and Houseknecht (2008), David Houseknecht (USGS, written commun., 2011), and a few deep wells in the IHS Energy Group (2010) dataset. The SAU has a potential $\mathrm{CO}_{2}$ storage reservoir area of about 54,000 acres and occurs between 9,400 and 13,000 ft below land surface with the most likely reservoir depth approximately 11,200 ft. Available data (IHS Energy Group, 2010; Wicks and others, 1991) indicate that the most likely gross reservoir thickness within the SAU is between 800 to $1,200 \mathrm{ft}$ with $1,000 \mathrm{ft}$ being the most likely gross thickness throughout the SAU. Published and proprietary data (Wicks and others, 1991; IHS Energy Group, 2010; David Houseknecht, USGS, written commun., 2011) suggest this interval has a net-to-gross ratio of about 0.35 , yielding minimum, maximum, and most likely estimates of average net-porous thickness of 280, 420, and $350 \mathrm{ft}$, respectively. Generally, porosity of the Kekiktuk Conglomerate in the Endicott field is high due to (1) development of secondary porosity associated with the LCU and (2) the coarse-grained character of the sandstone reservoirs (Wicks and others, 1991). Available data indicate that the average porosity of the net-porous intervals is between 12 and 25 percent with 21 percent being the most likely value across the SAU (Wicks and others, 1991; IHS Energy Group, 2010; David Houseknecht, USGS, written commun., 2011). Permeability measurements obtained from the same data sources range from 0.02 to 10,000 millidarcys (mD). Wicks and others (1991) reported that salinities in groundwater within the Endicott field exceed 10,000 milligrams per liter (mg/L); however, regional modeling by Hanor and others (2004) suggested that areas of low TDS concentrations may exist locally.

The methodology defined by Brennan and others (2010) and Blondes and others (2013) was used to determine the minimum and most likely volume of enclosed pore space. The maximum enclosed pore volume was calculated from the product of (1) the combined area of structural traps interpreted from Wicks and others (1991), Bird and others (2005), Alaska Department of Natural Resources, Division of Oil and Gas (2008), Nehring Associates (2010), and from structural maps generated from the IHS Energy Group (2010) dataset; (2) the maximum net-porous-interval thickness; and (3) the upper limit on average SAU porosity described above. 


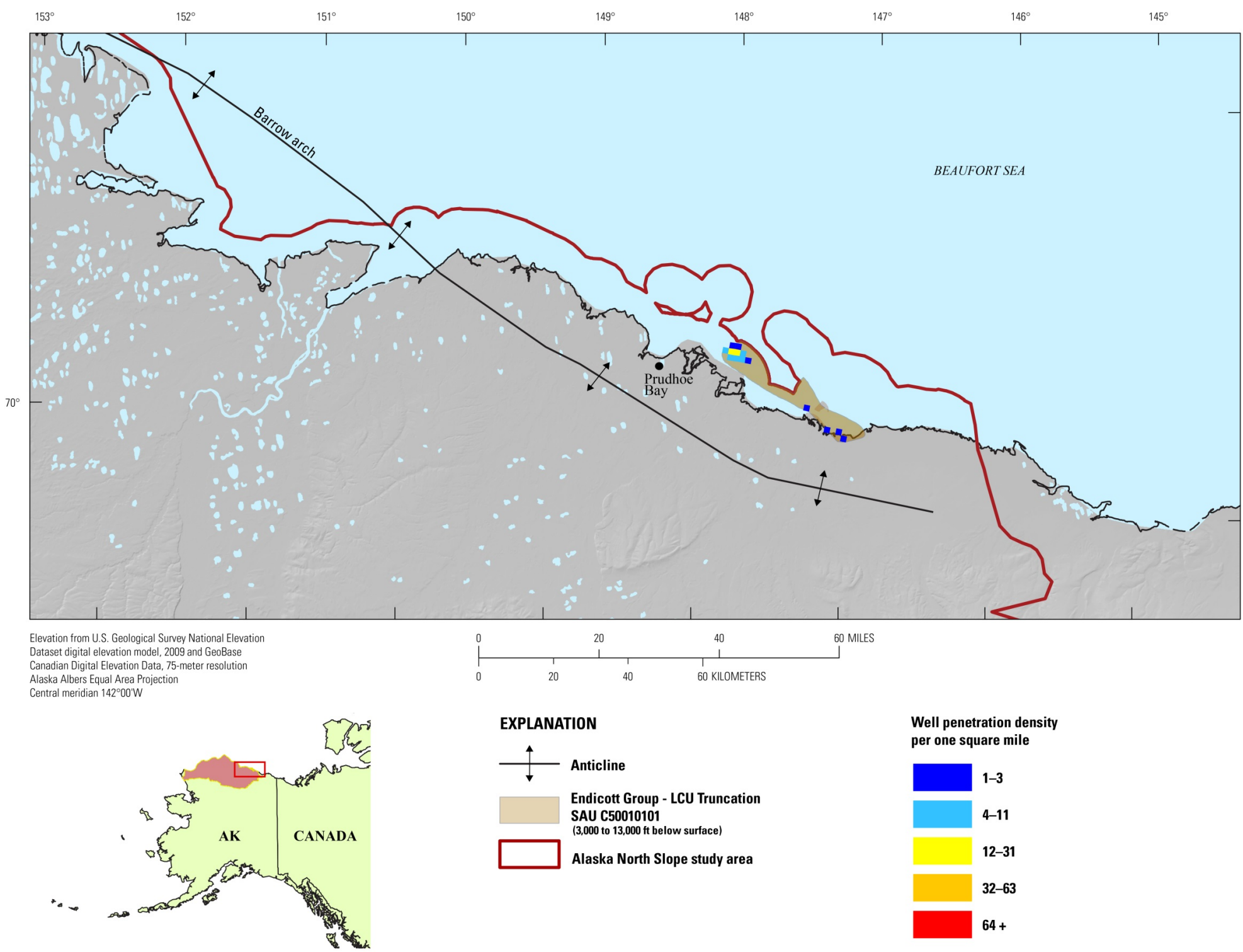

Figure 4. Map of the U.S. Geological Survey storage assessment unit (SAU) boundary for the Endicott Group-LCU Truncation SAU (C50010101) in the Alaska North Slope study area. Grid cells (one-square mile) represent counts of wells, displayed at bottom-hole locations, derived from ENERDEQ well database (IHS Energy Group, 2011) that have penetrated the reservoir-formation top. The study area boundary was modified from Houseknecht and Bird (2006). LCU, Lower Cretaceous unconformity. 


\title{
Endicott Group-Kayak Shale SAU C50010102
}

\author{
By Ernie R. Slucher
}

The Endicott Group-Kayak Shale SAU corresponds to the area where the Kekiktuk Conglomerate of the Endicott Group is overlain by the Kayak Shale, which serves as a regional caprock (figs. 3 and 5). Only areas where the Kayak Shale exceeds a lower thickness limit of about $100 \mathrm{ft}$ were included in the potential storage area. Areas at depths greater than 13,000 ft were not included because available data are insufficient to characterize storage potential at these reservoir depths. Furthermore, past studies indicate that sandstone in the Kekiktuk Conglomerate generally is silica-cemented and characterized by petrophysical properties indicative of poor reservoir quality across much of the Alaska North Slope (Wicks and others, 1991; John Wicks, oral commun., 2011). Therefore, the extent of the SAU is limited to an area of the central North Slope between ANWR and NPRA, extending north to slightly beyond the crest of the Barrow arch (see figs. 2 and 5) (Houseknecht and Bird, 2006). The SAU area corresponds to the area where some potential exists for localized secondary porosity, as is typical of the Endicott-LCU Truncation SAU.

The Endicott Group-Kayak Shale SAU occupies an area of around 365,000 acres (fig. 5) and occurs between about 9,300 and 13,000 ft below the surface with a most likely reservoir depth of around $11,500 \mathrm{ft}$. The boundaries of the SAU are defined mainly by data on the Endicott Group in the IHS Energy Group (2010) dataset. Available data (Wicks and others, 1991; Kenneth Bird, USGS, written commun., 2007; IHS Energy Group, 2010) suggest the most likely gross reservoir thickness within the SAU is from 360 to $560 \mathrm{ft}$ with $460 \mathrm{ft}$ being the most likely thickness throughout the SAU. Published and proprietary data (Wicks and others, 1991; David Houseknecht, USGS, written commun., 2011) suggest the reservoir interval has a net-to-gross ratio of 0.38 indicating that the most likely SAU-wide average net-porous thickness is from 137 to $213 \mathrm{ft}$, and most likely to be $175 \mathrm{ft}$. Given that secondary porosity is less likely to exist in the area of this assessment unit, because the LCU is stratigraphically above the Kekiktuk Conglomerate, reservoir porosity is likely to be lower than in the Endicott GroupLCU Truncation SAU. Available data suggest that average reservoir porosity is between 8 and 18 percent and is most likely 11 percent (Wicks and others, 1991; IHS Energy Group, 2010; David Houseknecht, USGS, written commun., 2011). Reservoir permeability appears to range from 0.02 to 1,200 mD (Wicks and others, 1991; IHS Energy Group, 2010; David Houseknecht, USGS, written commun., 2011). Wicks and others (1991) reported that salinities in groundwater within the Endicott field at the eastern end of the SAU exceed 10,000 $\mathrm{mg} / \mathrm{L}$; however, regional modeling by Hanor and others (2004) suggested areas of groundwater with low TDS concentrations may exist locally.

The methodology defined by Brennan and others (2010) and Blondes and others (2013) was used to determine the minimum and most likely volumes of enclosed pore space. The maximum enclosed pore volume was calculated from the product of (1) combined area of structural traps interpreted from Wicks and others (1991), Bird and others (2005), Alaska Department of Natural Resources, Division of Oil and Gas (2008), Nehring Associates (2010), and from structural maps generated from the IHS Energy Group (2010) dataset; (2) the upper bound on net-porous-interval thickness; and, (3) the upper bound on average SAU porosity described above. 


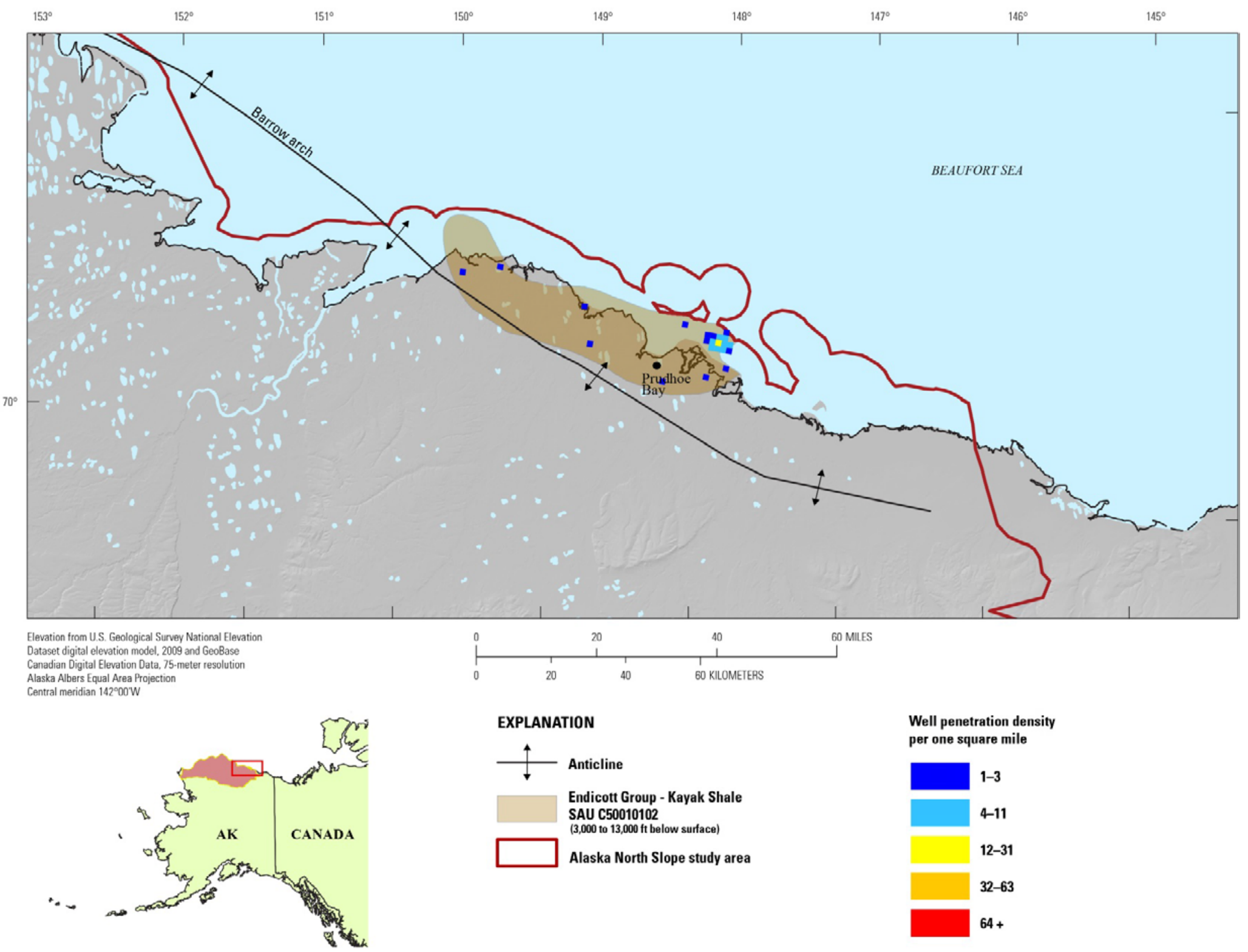

Figure 5. Map of the U.S. Geological Survey storage assessment unit (SAU) boundary for the Endicott Group-Kayak Shale SAU (C50010102) in the Alaska North Slope study area. Grid cells (one-square mile) represent counts of wells, displayed at bottom-hole locations, derived from ENERDEQ well database (IHS Energy Group, 2011) that have penetrated the reservoir-formation top. The study area boundary was modified from Houseknecht and Bird (2006). 


\title{
Lower Ellesmerian SAU C50010103 and Lower Ellesmerian Deep SAU C50010104
}

\author{
By Tina L. Roberts-Ashby and Sean T. Brennan
}

The rocks of the lower Ellesmerian sequence form a composite $\mathrm{CO}_{2}$ storage reservoir that includes the Carboniferous to Lower Permian Lisburne Group and the Permian Echooka Formation (fig. 3). The Lisburne Group primarily consists of limestone and dolostone with some shale, sandstone, and nodular chert. The group has been subdivided into formations with names that vary across the North Slope region (Kirschner and Rycerski, 1988; Moore and others, 1994). Throughout most of the Alaska North Slope region, the Lisburne Group consists of the Alapah Limestone and the overlying Wahoo Limestone; however, in the northeastern Brooks Range these units are underlain by the Wachsmuth Limestone (Moore and others, 1994). On the far western North Slope, the Lisburne Group consists of (ascending) the Nasorak Formation, Kogruk Formation, and Tupik Formation (Moore and others, 1994). The Lisburne Group was deposited on a wide, low-gradient ramp that was part of a south-facing (present-day orientation), passive continental margin (Hakkila, 1987; Moore and others, 1994; Hanor and others, 2004). The group is complex in depositional nature and includes carbonate platform, carbonate ramp, and deep- and shallow-marine siliciclastic facies (Moore and others, 1994; Dumoulin and others, 2006). The Echooka Formation, which unconformably overlies the Lisburne Group, contains fossiliferous, calcareous, and quartzose sandstone with some limestone, basal chert conglomerate, and interbedded shale, siltstone, and glauconitic and phosphatic grains (Hakkila, 1987; Moore and others, 1994; Wilson and others, 2001). The Echooka Formation is subdivided (ascending) into the Joe Creek Member and Ikiakpaurak Member (Moore and others, 1994). The Echooka Formation was deposited during the northward transgression of the Sadlerochit sea during Permian time (Hakkila, 1987; Moore and others, 1994; Wilson and others, 2001). The Echooka Formation is overlain by the Ivishak Formation, and together, the two formations form the Sadlerochit Group (fig. 3) (Moore and others, 1994). The Kavik Member, basal member of the Ivishak Formation, is a pro-delta deposit of dark, marine, silty shale with minor siltstone that is as much as $700 \mathrm{ft}$ thick (Moore and others, 1994; Wilson and others, 2001). The Kavik Member is interpreted as the regional seal for both of the Lower Ellesmerian composite SAUs presented in this section.

Two potential $\mathrm{CO}_{2}$ storage-reservoir units are identified in the lower Ellesmerian rocks of the Alaska North Slope: (1) the Lower Ellesmerian SAU between 3,000- and 13,000-ft subsurface depth and (2) the Lower Ellesmerian Deep SAU below 13,000-ft subsurface depth (fig. 6) with the Lisburne Group making up the majority of the reservoir rock within the SAUs. The Lower Ellesmerian SAU encompasses an area of about 9,016,000 acres ( \pm 10 percent) and the Lower Ellesmerian Deep SAU encompasses about $28,574,000$ acres ( \pm 10 percent).

The boundaries of the Lower Ellesmerian SAUs are defined by the 3,000-ft and 13,000-ft reservoir-top depths interpreted from 70 borehole penetrations (Kenneth Bird, USGS, written commun., 2007; IHS Energy Group, 2010), faults associated with the Brooks Range, and the Alaska State-Federal waters boundary. The rocks within the lower Ellesmerian sequence deepen significantly to the south, toward the Brooks Range, and on average are 1,000 to 2,000 ft thick (standard SAU) and 2,400 to 2,900 $\mathrm{ft}$ thick (deep SAU) with a most likely thickness of 1,500 ft (standard SAU) and 3,600 $\mathrm{ft}$ (deep SAU), as indicated by isopach maps (Pessel and Tailleur, 1978; Dumoulin and others, 2006) and cross sections (Moore and others, 1994; Bird, 1999; Houseknecht and Bird, 2004). Data availability in the deeper rocks of the lower Ellesmerian sequence, specifically in the area of the Lower Ellesmerian Deep SAU, is poor due to the lack of well penetrations and petroleum exploration. Most wells that penetrate the Echooka Formation and Lisburne Group are located within the shallower rocks found in the Lower 
Ellesmerian SAU, especially around Prudhoe Bay where a majority of the petroleum fields are located. Because little well data were available for the Lower Ellesmerian Deep SAU, published stratigraphic cross sections, seismic data, and isopachs were used to estimate the depth range for the SAU, as well as the gross thickness of the reservoir rocks (Moore and others, 1994; Bird, 1999; Houseknecht and Bird, 2004; Schenk and Houseknecht, 2008).

Most porosity in the Lisburne Group is secondary resulting from dissolution, karstification, and dolomitization (Wood and Armstrong, 1975; Jameson, 1994; Dumoulin and others, 2004). However, because secondary porosity development is at least partly related to beveling of the LCU, porosity tends to decrease south of Prudhoe Bay, especially into the area that encompasses the Lower Ellesmerian Deep SAU. Reservoirs exist in limestones, dolostones, and sandstones of the lower Ellesmerian sequence, but the dolostones have the best reservoir quality. Porosity of the lower Ellesmerian decreases with depth, and the average value is between 5 and 18 percent in the Lower Ellesmerian SAU and between 3 and 10 percent in the Lower Ellesmerian Deep SAU (David Houseknecht, USGS, written commun., 2011). Net-porous-interval thickness was estimated by multiplying the total storage-formation thickness by an average net-to-gross ratio, which was interpreted from geophysical logs. A net-to-gross ratio of 0.40 was used for the Lower Ellesmerian SAU resulting in an average net-porous-interval thickness between 400 to $800 \mathrm{ft}$ with a most likely value of $600 \mathrm{ft}$. A net-to-gross ratio of 0.20 was used for the Lower Ellesmerian Deep SAU resulting in an average net-porous-interval thickness between 480 to $720 \mathrm{ft}$ with a most likely value of $580 \mathrm{ft}$. The minimum and most likely permeability values $(0.002$ $\mathrm{mD}$ and $0.5 \mathrm{mD}$, respectively) are the same for both Lower Ellesmerian SAUs; however, due to differences in diagenetic alteration, maximum recorded permeability for the Lower Ellesmerian SAU is $850 \mathrm{mD}$, whereas a much smaller value of $8 \mathrm{mD}$ is observed in the Lower Ellesmerian Deep SAU (David Houseknecht, USGS, written commun., 2011).

Little water-quality data are available for the Lower Ellesmerian SAUs. However, a regional salinity structure and groundwater-flow study of the central North Slope by Hanor and others (2004) provides salinity data that indicate that a majority (most likely 90 to 95 percent) of both the standard and deep Lower Ellesmerian SAUs have TDS concentrations greater than 10,000 $\mathrm{mg} / \mathrm{L}$, thereby making them largely suitable for $\mathrm{CO}_{2}$ storage based upon regulations set forth by the U.S. Environmental Protection Agency (2010).

In order to calculate the maximum buoyant pore volume within structural and stratigraphic closures, known and anticipated closure areas were combined with upper bounds on average regional reservoir thickness and porosity. The known closure areas were estimated based upon knowledge of the petroleum producing regions within the SAU, and the anticipated closure areas were estimated using an understanding of the nature of the known closure areas coupled with knowledge of the reservoir rocks within the SAUs. An assumption underlying this calculation is that potential exists for additional uncharged or undiscovered structural and stratigraphic closures outside of regions of historical hydrocarbon production. 


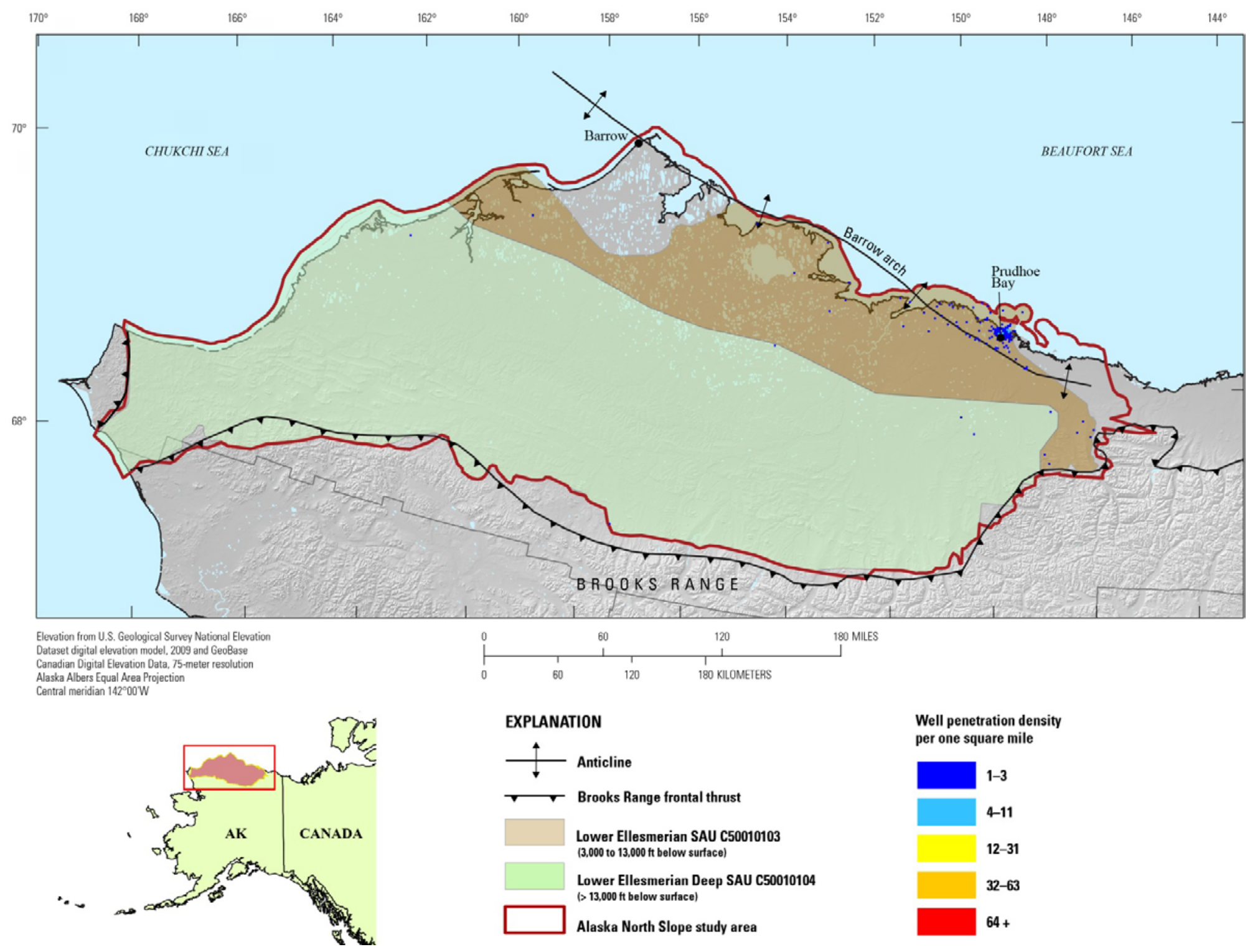

Figure 6. Map of the U.S. Geological Survey storage assessment unit (SAU) boundary for the Lower Ellesmerian SAU (C50010103) and the Lower Ellesmerian Deep SAU (C50010104) in the Alaska North Slope study area. Grid cells (one-square mile) represent counts of wells, displayed at bottomhole locations, derived from ENERDEQ well database (IHS Energy Group, 2011) that have penetrated the reservoir-formation top. The study area boundary was modified from Houseknecht and Bird (2006). 


\title{
Lower Ellesmerian-LCU Truncation SAU C50010105
}

\author{
By Tina L. Roberts-Ashby and Sean T. Brennan
}

Throughout much of the Alaska North Slope, the Lower Triassic Kavik Member of the Ivishak Formation forms the regional seal for the rocks of the lower Ellesmerian sequence (fig. 3). However, in the Prudhoe Bay area, the Kavik Member is absent owing to erosion beneath the LCU, and the Cretaceous pebble shale forms a topseal for lower Ellesmerian strata, thereby defining a distinct SAU. The pebble shale is up to $525 \mathrm{ft}$ thick and is composed of black, organic-rich, marine shale that contains some matrix-supported pebbles of chert and quartz and minor amounts of sandstone (Moore and others, 1994). The Permian Echooka Formation also is eroded beneath the LCU in this region, such that the Lower Ellesmerian-LCU Truncation SAU reservoir is composed of only the Carboniferous and Lower Permian Lisburne Group.

The Lower Ellesmerian-LCU Truncation SAU is approximately 246,000 acres $( \pm 10$ percent) and ranges from 9,000 to $11,800 \mathrm{ft}$ deep with a most likely depth of 10,000 ft (fig. 7). The boundaries of the SAU are defined by the 3,000-ft reservoir-top depth, interpreted from 17 well penetrations (Kenneth Bird, USGS, written commun., 2007; IHS Energy Group, 2010), faults associated with the Brooks Range, the State-Federal waters boundary, and cross sections indicating the extent of the LCU truncation (Wicks and others, 1991; Moore and others, 1994; Bird, 1999; Schenk and Houseknecht, 2008). On average, gross thickness of the SAU is between 1,100 and 1,700 ft with a most likely thickness of 1,300 ft, as indicated by published isopach maps (Dumoulin and others, 2006) and cross sections (Moore and others, 1994; Bird, 1999; Houseknecht and Bird, 2004).

Porosity in the Lower Ellesmerian-LCU Truncation SAU is significantly higher than the Lower Ellesmerian and Lower Ellesmerian Deep SAUs, and the average is between 10 and 25 percent with a most likely value of 15 percent (David Houseknecht, USGS, written commun., 2011). Higher porosity in this SAU is due to extensive dolomitization and karstification associated with (1) intermittent, local exposure during the Pennsylvanian, (2) Permian-Triassic subaerial exposure, (3) dissolution during exposure associated with development of the LCU, and (4) Cretaceous-Tertiary burial dissolution (Jameson, 1994). More extensive secondary porosity development throughout the Lisburne Group in this area results in a much thicker netporous interval than that of the Lower Ellesmerian and Lower Ellesmerian Deep SAUs. Net-porous-interval thickness was estimated by multiplying the total storage-formation thickness by an average net-to-gross ratio, which was interpreted from geophysical logs. A net-to-gross ratio of 0.70 was used, resulting in an average net-porous-interval thickness between 770 and 1,470 ft with a most likely value of 1,050 ft. Permeability in the Lower Ellesmerian-LCU Truncation SAU is also higher than the Lower Ellesmerian and Lower Ellesmerian Deep SAUs and ranges from 0.1 to $850 \mathrm{mD}$ with a most likely value of $50 \mathrm{mD}$ (David Houseknecht, USGS, written commun., 2011).

Because little water-quality data are available for the lower Ellesmerian sequence in the Alaska North Slope region, the Hanor and others (2004) regional salinity structure and groundwater-flow study of the central North Slope was used to identify areas of potential fresh groundwater (TDS concentration below $10,000 \mathrm{mg} / \mathrm{L}$, as discussed above). Salinity data provided in Hanor and others (2004) indicate that a majority of the SAU (most likely 90 percent) is suitable for $\mathrm{CO}_{2}$ storage based upon regulations set forth by the U.S. Environmental Protection Agency (2010).

In order to calculate the maximum buoyant pore volume within structural and stratigraphic closures, known and anticipated closure areas were combined with upper bounds of average regional reservoir thickness and porosity. The known closure areas were estimated based upon knowledge of the petroleum producing regions within the SAU, and the anticipated closure areas were estimated using an understanding of the nature of the known closure areas coupled with knowledge of the reservoir rocks within the SAUs. An assumption underlying this calculation is that potential exists for additional uncharged or undiscovered structural and stratigraphic closures outside of regions of historical hydrocarbon production. 


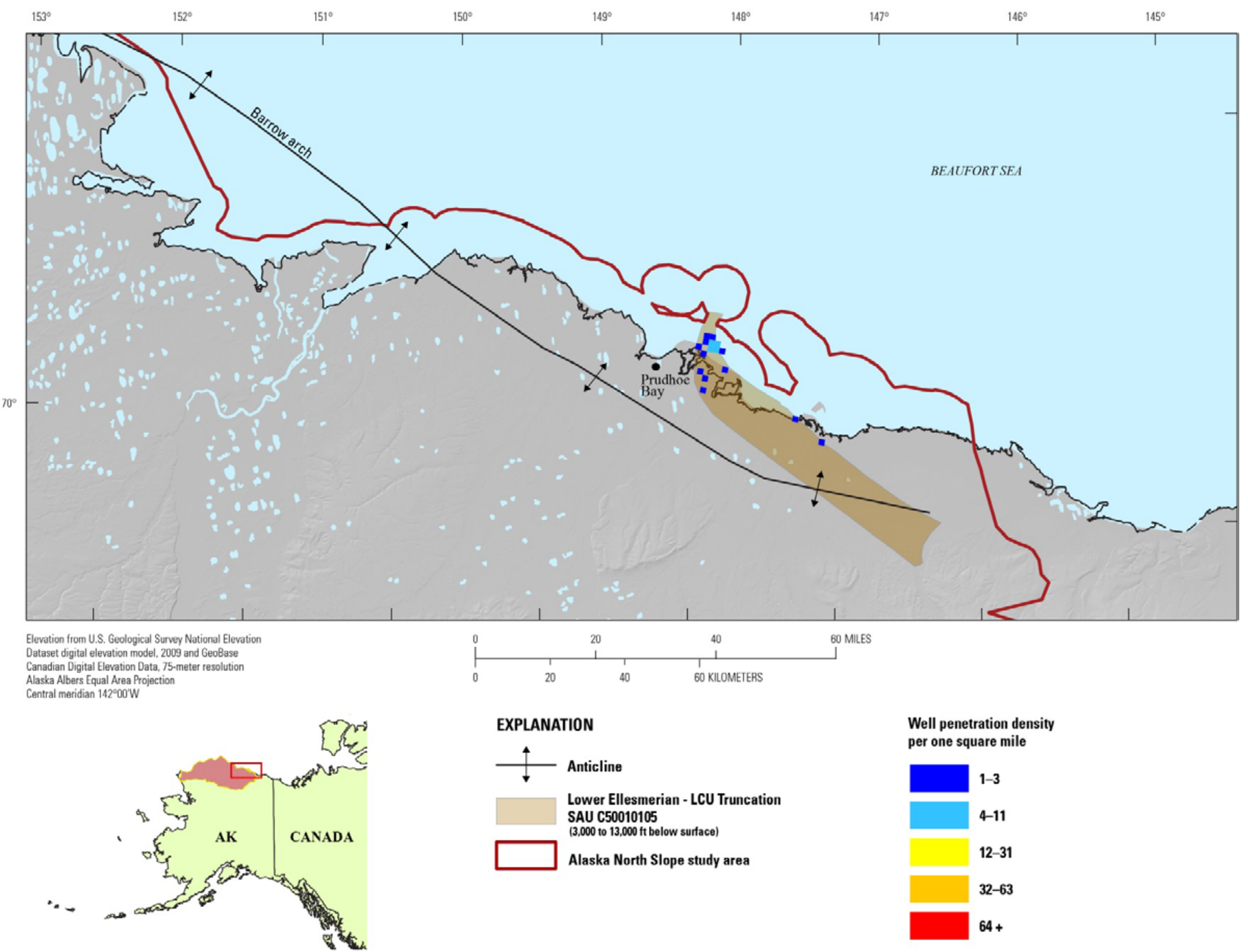

Figure 7. Map of the U.S. Geological Survey storage assessment unit (SAU) boundary for the Lower Ellesmerian-LCU SAU (C50010105) in the Alaska North Slope study area. Grid cells (one-square mile) represent counts of wells, displayed at bottom-hole locations, derived from ENERDEQ well database (IHS Energy Group, 2011) that have penetrated the reservoir-formation top. The study area boundary was modified from Houseknecht and Bird (2006). LCU, Lower Cretaceous unconformity. 


\title{
Beaufortian and Upper Ellesmerian SAU C50010106
}

\author{
By Matthew D. Merrill and Colin A. Doolan
}

The Beaufortian and Upper Ellesmerian SAU is a composite assessment unit that includes reservoir intervals ranging from the Lower Triassic Ledge Sandstone Member of the Ivishak Formation to the Lower Cretaceous Kemik Sandstone (fig. 3). A full list of the reservoir units in the SAU includes the Ledge Sandstone and Fire Creek Siltstone Members of the Ivishak Formation, the Sag River Sandstone, the informal Barrow, Simpson, and Alpine sandstones, the Kuparuk Formation, and the Kemik Sandstone (see Hubbard and others, 1987; Masterson and Eggert, 1992; Houseknecht and Bird, 2004). According to a revised stratigraphic nomenclature of Mull and others (2003), the sandstone units mentioned above fall within the upper Ellesmerian and Beaufortian sequences of the Alaska North Slope. A clastic shelf with a sediment source to the north (present-day orientation) served as the depositional setting for the units of this SAU with transgressive-regressive cycles determining the lithology and extent of the sands and shales (Houseknecht and Bird, 2004). The Kingak Shale and pebble shale are the seals for this SAU with thicknesses of roughly 2,000 and $200 \mathrm{ft}$, respectively (IHS Energy Group, 2010; David Houseknecht, USGS, written commun., 2011).

The SAU has an area of about 17,209,000 acres (fig. 8). The northern border of the SAU is marked by the State-Federal waters boundary and the 3,000-ft overburden contour around the area of Barrow Alaska (fig. 3) (Kenneth Bird, USGS, written commun., 2007; IHS Energy Group, 2010). To the south, the edge of the SAU is based on the 13,000-ft overburden contour (Saltus and Bird, 2003), and the southern limit of the SAU is just north of the limit of Ivishak Formation and Sag River Sandstone according to Moore and others (1994). In the east, the SAU boundary is the truncation edge of reservoir strata beneath the LCU, and to the west, the limit is the Alaska State waters boundary or the 13,000-ft overburden contour.

Determining thickness and net-porous thickness across the SAU proved challenging due to a lack of data in the southern part of the SAU. Isopach maps from Moore and others (1994) and formation tops from boreholes (IHS Energy Group, 2010; David Houseknecht, USGS, written commun., 2011) indicate that the average total SAU thickness ranges from approximately 2,000 to 4,000 ft. In aggregate, the various sandstone units account for a mean of $250 \pm 100 \mathrm{ft}$ of net-porous thickness, based on detailed well log analyses of the Sag River Sandstone and Ledge Sandstone and Fire Creek Siltstone Members (David Houseknecht, USGS, written commun., 2011).

Rock properties, such as porosity and permeability, vary widely across the SAU. Proprietary data used in USGS oil and gas assessments indicate that sandstone reservoirs exhibit porosities of 5 to 32 percent overall with an average porosity of between 9 to 17 percent (Nehring Associates, 2010). Mean reservoir porosity generally decreases as burial depth increases. Permeability data from the same proprietary sources show that the major producing units, like the Ledge Member, have the highest permeability. However, permeability across SAU ranges from 0.05 to $1,000 \mathrm{mD}$.

Groundwater-quality data for the Alaska North Slope are not common in the literature or available databases. A salinity investigation based on spontaneous potential well logs (Hanor and others, 2004) is the best resource available, and it suggests that groundwater in the Beaufortian and upper Ellesmerian strata generally has TDS concentrations of above $10,000 \mathrm{mg} / \mathrm{L}$ within the SAU. There are areas with groundwater TDS concentration below $10,000 \mathrm{mg} / \mathrm{L}$; however, they were not incorporated into storage calculations.

Seismically based structure analysis by Saltus and others (2002) provides closure mapping for the Ledge Sandstone Member and Sag River Sandstone; these closure areas account for between 2 and 4 percent of the area of NPRA and are incorporated in the calculation of enclosed pore space within the reservoir interval. 


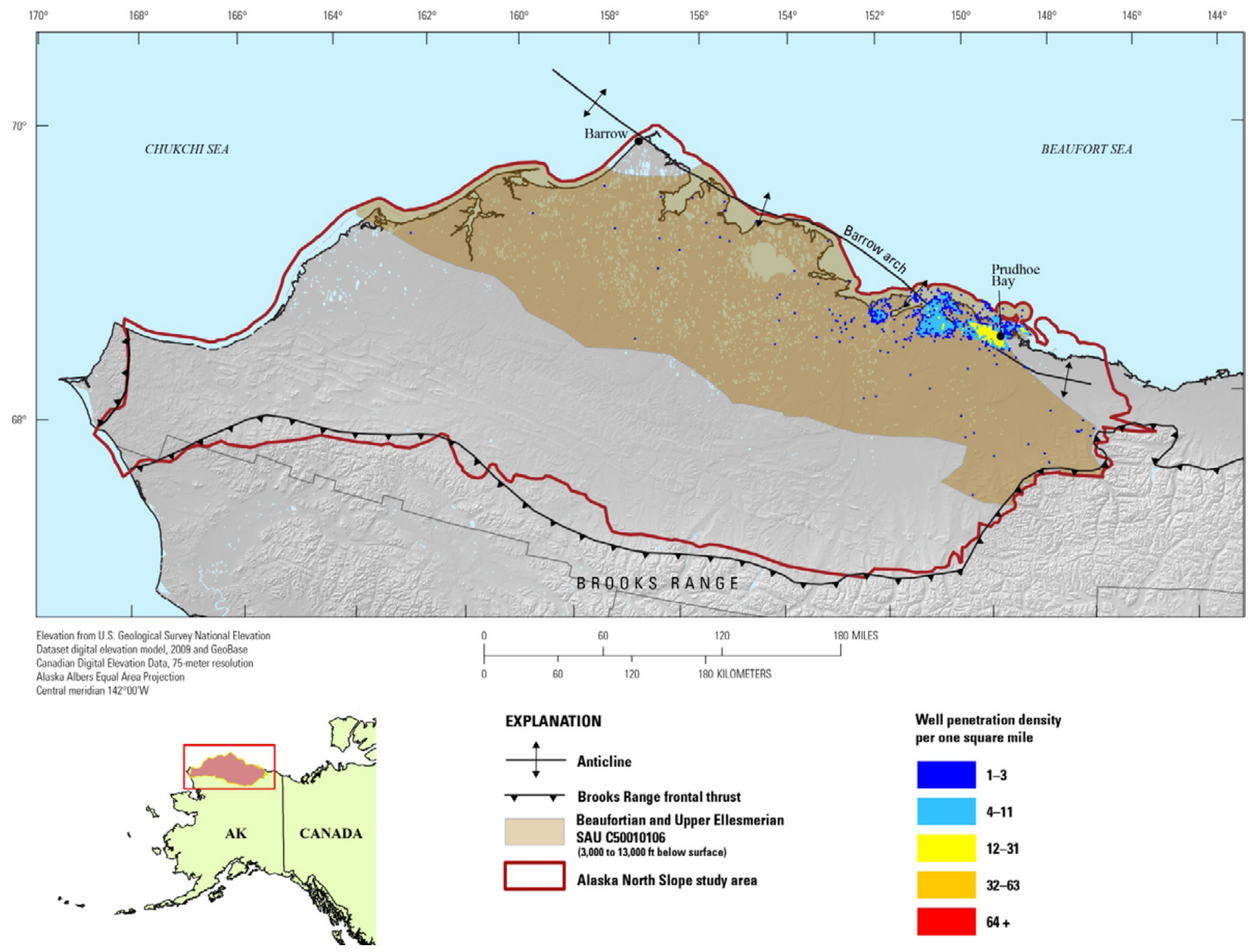

Figure 8. Map of the U.S. Geological Survey storage assessment unit (SAU) boundary for the Beaufortian and Upper Ellesmerian SAU (C50010106) in the Alaska North Slope study area. Grid cells (one-square mile) represent counts of wells, displayed at bottom-hole locations, derived from ENERDEQ well database (IHS Energy Group, 2011) that have penetrated the reservoir-formation top. The study area boundary was modified from Houseknecht and Bird (2006). 


\title{
Lower Torok Formation SAU C50010107
}

\author{
By Jacob A. Covault
}

The Lower Cretaceous, lower part of the Torok Formation of the Brookian sequence (fig. 3) is isolated from upper part (see below) in the Colville Basin, although both parts may contain rock with $\mathrm{CO}_{2}$ reservoir potential (fig. 3). The lower Torok Formation is variably referred to as the bottomset package of the slope wedge of Houseknecht and others (2009a) and the foredeep wedge of Houseknecht and others (2009b). The reservoir-prone lower Torok Formation foredeep wedge is approximately $3,500 \mathrm{ft}$ thick on average and predominantly includes fine- to medium-grained siliciclastic sandstone interbedded with mudstone (Houseknecht and others, 2009b). Mull and others (2003) generally described the outcropping, relatively coarse-grained Torok Formation as oil-stained, amalgamated sandstone beds that can total as much as $300 \mathrm{ft}$ in thickness. The subsurface seismic-reflection character of the foredeep wedge has been extensively documented by Houseknecht and others (2009a,b): clinoform bottomset seismic facies are parallel and subparallel, laterally continuous, moderate- to highamplitude seismic reflections. The top of the seismic-reflection package of bottomset facies is defined by the downlap of overlying foreset seismic reflections, whereas the base of the package is a regional unconformity (Houseknecht and others, 2009b). These reservoir-prone foredeep-wedge deposits are capped by more than 1,000 ft of finer grained foreset deposits, which are interpreted to serve as a regional seal (Houseknecht and others, 2009b). The Torok Formation is interpreted to represent west-toeast progradational-slope clinothem deposition in the Colville Basin (Houseknecht and others, 2009a,b). The reservoir-prone bottomset strata are interpreted to be deep-marine turbidite systems deposited during a period of falling and low relative sea level (Houseknecht and Schenk, 2001, 2007; Houseknecht and others, 2009a,b). The overlying finer grained foreset strata are interpreted to represent marine-slope deposition (Houseknecht and Schenk, 2007; Houseknecht and others, 2009a,b).

The lower Torok Formation is a potential reservoir unit for $\mathrm{CO}_{2}$ storage between 3,000- and 11,000-ft subsurface depths (fig. 9). The SAU boundary is defined by the 3,000-ft drilling depth from well penetrations (IHS Energy Group, 2010), regional subsurface correlations of Decker $(2007,2010)$, the extent of deep-marine turbidite sandstone mapped by Houseknecht and Schenk (2001) and Houseknecht and others (2009a,b), and the Brooks Range thrust front mapped by Houseknecht and Schenk (2001, their figure 4). The total storage-formation thickness for the reservoir unit was determined from regional seismic-reflection correlations (for example, Potter and Moore, 2003; Houseknecht and others, 2009b). The thickness of the net-porous interval was determined by multiplying the gross stratigraphic thickness by a net-to-gross thickness ratio of approximately 0.5 from regional subsurface correlations of Decker (2010). Porosity is between approximately 8 and 17 percent on average; permeability ranges from 0.002 to $80 \mathrm{mD}$ (Potter and Moore, 2003; Helmold and others, 2006). Water-quality measurements indicate that groundwater in the formation is highly saline (specifically, TDS concentrations are greater than 10,000 mg/L) (Breit, 2002; Hanor and others, 2004).

The minimum and most likely volumes of enclosed pore space were calculated from the product of (1) the minimum and most likely measurements of the area of Torok Formation structural traps interpreted from structures in NPRA mapped by Saltus and others (2002), (2) minimum and most likely measurements of net sandstone thickness within a buoyant trap (Bird and Houseknecht, 2002), and (3) minimum and most likely measurements of porosity within buoyant traps (Bird and Houseknecht, 2002). The maximum buoyant-trapping pore volume was calculated in a similar fashion using upper bounds on closure area (Saltus and others, 2002) and upper bounds on net sandstone thickness and porosity described above. Similar to previous SAUs, we assumed a potential for $\mathrm{CO}_{2}$ sequestration in uncharged traps. 


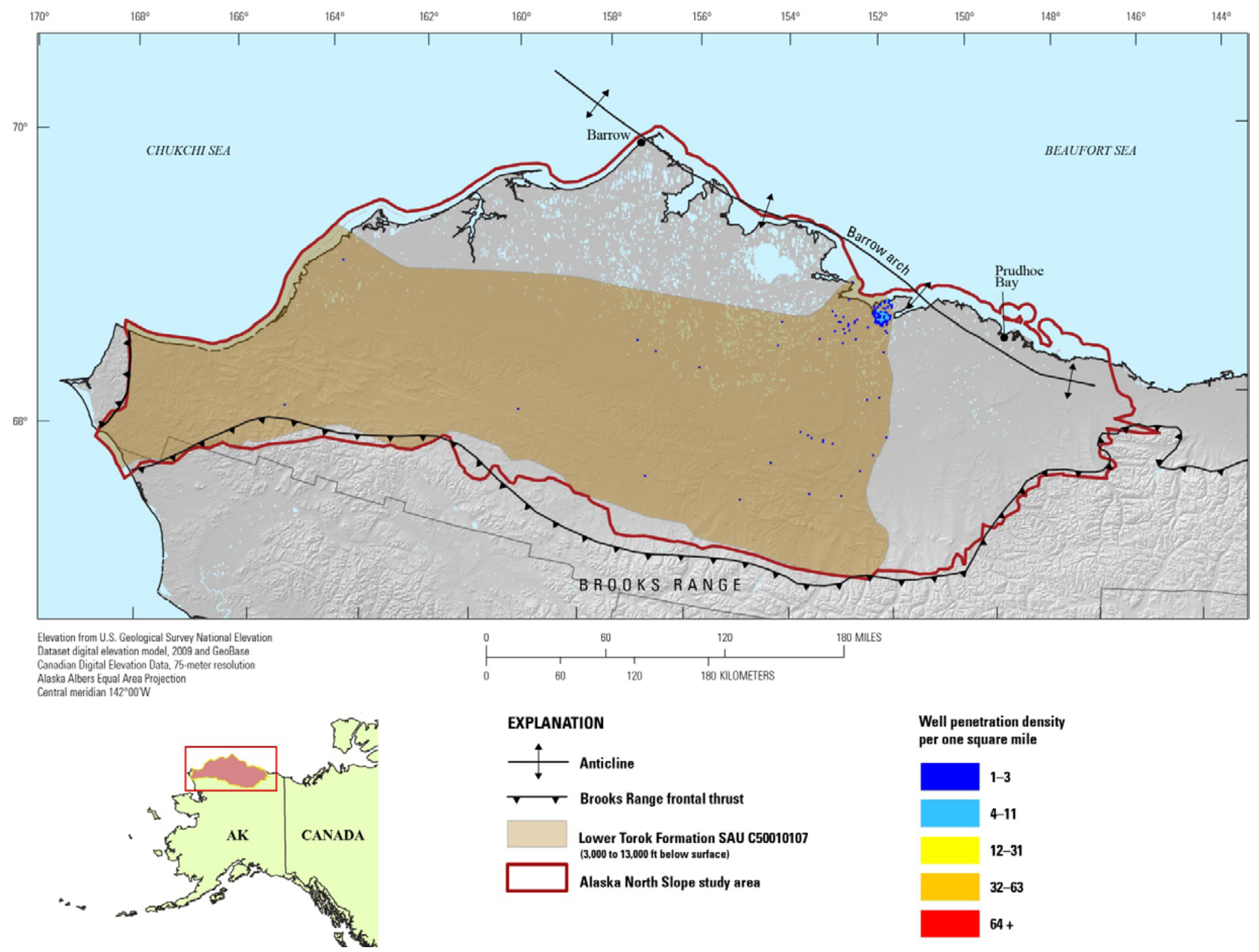

Figure 9. Map of the U.S. Geological Survey storage assessment unit (SAU) boundary for the Lower Torok Formation SAU (C50010107) in the Alaska North Slope study area. Grid cells (one-square mile) represent counts of wells, displayed at bottom-hole locations, derived from ENERDEQ well database (IHS Energy Group, 2011) that have penetrated the reservoir-formation top. The study area boundary was modified from Houseknecht and Bird (2006). 


\title{
Upper Torok Formation SAU C50010108
}

\author{
By Jacob A. Covault
}

The upper part of the reservoir-prone Cretaceous Torok Formation is stratigraphically isolated from the foredeep wedge package (Lower Torok Formation SAU) in the Colville Basin (fig. 3) (Decker and others, 2008). This upper part of the Torok Formation is informally referred to as the Gilead sandstone (Decker and others, 2008). The unit is approximately 2,000 $\mathrm{ft}$ thick on average and, similar to the Lower Torok Formation SAU, is characterized as a bottomset package consisting of fine- to medium-grained siliciclastic sandstone interbedded with mudstone (Houseknecht and others, 2009b). Decker and others (2008) described outcropping Gilead sandstone as fine- to coarse-grained, litharenite with amalgamated sandstone beds and intervening finer grained, thinner beds. The subsurface seismicreflection character of the sandstone-rich bottomset package of the Torok Formation has been extensively documented by Houseknecht and others (2009a,b): seismic facies are parallel and subparallel, laterally continuous, moderate- to high-amplitude seismic reflections. The Gilead sandstone overlies finer grained deposits, which are interpreted to seal the lower Torok Formation foredeep wedge SAU, and underlies the approximately 100-ft-thick relatively fine-grained Hue Shale and the greater than 1,000-ft-thick Seabee Formation (fig. 3). This greater than 1,000-ft-thick composite package of fine-grained sedimentary rock is interpreted to be a seal for the underlying Gilead sandstone of the upper part of the Torok Formation. The Gilead sandstone is interpreted to represent the culmination of Cretaceous Torok Formation deep-marine turbidite deposition during a period of falling and low sea level (David Houseknecht, USGS, oral commun., 2011).

The upper Torok Formation Gilead sandstone is a potential reservoir unit for $\mathrm{CO}_{2}$ storage between 5,000- and 10,000-ft subsurface depths (fig. 10). The SAU boundary is defined by the extent of the Gilead sandstone mapped in seismic-reflection data by Houseknecht and others (2009b) and David Houseknecht (USGS, oral commun., 2011). The thickness of the net-porous interval was determined by multiplying the gross stratigraphic thickness by a net-to-gross ratio of approximately 0.5 from regional subsurface correlations of Decker (2010) for the Lower Torok Formation SAU. Reservoir-quality data were interpreted from the analogous Lower Torok Formation SAU. Average reservoir porosity is between approximately 8 and 17 percent; permeability ranges from 0.002 to $80 \mathrm{mD}$ (Potter and Moore, 2003; Helmold and others, 2006). Water-quality measurements indicate that groundwater in the Torok is predominantly saline (greater than 10,000 mg/L of TDS) (Breit, 2002; Hanor and others, 2004).

The minimum and most likely volumes of enclosed pore space were calculated from the product of (1) the minimum and most likely areas of Gilead sandstone structural reservoir traps interpreted from closure area estimated for the Brookian clinoform assessment units of the USGS National Oil and Gas Assessment (NOGA) of the central North Slope region by Bird and others (2005), (2) minimum and most likely measurements of net sandstone thickness within a buoyant trap (Bird and others, 2005), and (3) minimum and most likely measurements of porosity within buoyant traps (Bird and others, 2005). The maximum buoyant-trapping pore volume was calculated in a similar fashion using upper bounds on closure area (Bird and others, 2005) and upper bounds on net sandstone thickness and porosity described above. Similar to previous SAUs, we assumed a potential for $\mathrm{CO}_{2}$ sequestration in uncharged traps. 


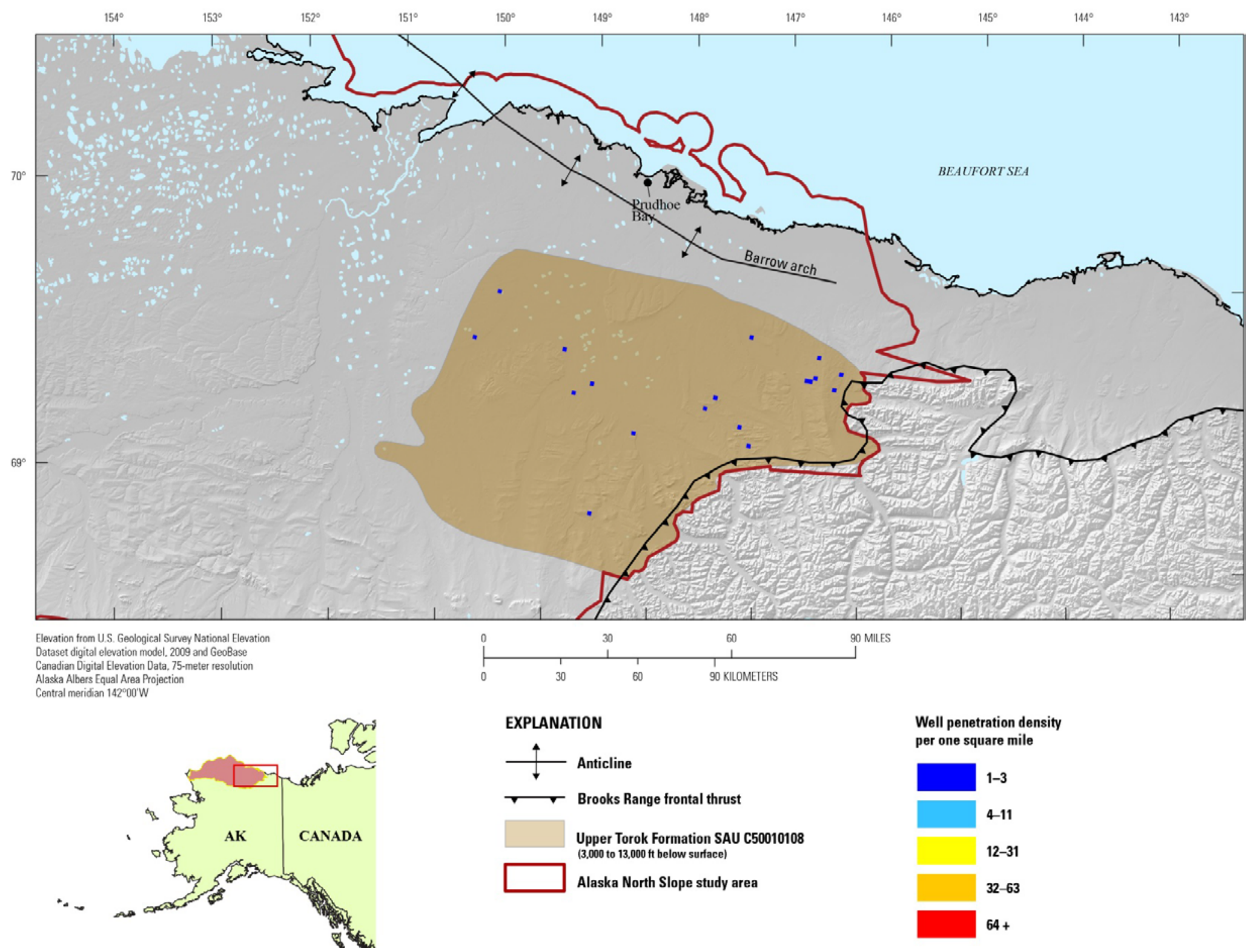

Figure 10. Map of the U.S. Geological Survey storage assessment unit (SAU) boundary for the Upper Torok Formation SAU (C50010108) in the Alaska North Slope study area. Grid cells (one-square mile) represent counts of wells, displayed at bottom-hole locations, derived from ENERDEQ well database (IHS Energy Group, 2011) that have penetrated the reservoir-formation top. The study area boundary was modified from Houseknecht and Bird (2006). 


\title{
Nanushuk Formation SAU C50010109
}

\author{
By Jacob A. Covault
}

The Nanushuk Formation of the Brookian sequence (fig. 3) is approximately 3,900 ft thick on average and predominantly includes very fine to medium-grained, locally fossiliferous siliciclastic sandstone with conglomerate (Mull and others, 2003). The subsurface seismic-reflection character of the Nanushuk Formation has been documented by Houseknecht and others (2010): clinoform topset acoustic facies are parallel and subparallel, laterally continuous, moderate- to high-amplitude seismic reflections. This package of topset seismic reflections overlies foreset seismic reflections of the Torok Formation (Houseknecht and others, 2009a,b). The Nanushuk Formation is capped by approximately 100 to $200 \mathrm{ft}$ of the relatively fine grained Hue Shale and greater than 1,000 ft of Seabee Formation, which are interpreted to serve as regional seals (Houseknecht and Schenk, 2005). The Nanushuk Formation is generally interpreted to represent west-to-east progradational deltaic-topset clinothem deposition across the Colville Basin (Houseknecht and others, 2009a,b). These strata are interpreted to be proximal, landward equivalents of the deep-marine slope and base-of-slope Torok Formation clinothem sequences (Houseknecht and others, 2009a,b). Reciprocal deposition driven by relative sea level fluctuations is interpreted to be recorded in the Nanushuk and Torok Formations: when sea level fell and was relatively low, accommodation was located in deeper water across the slope and basin floor and Torok facies were deposited; as sea level rose, accommodation was relocated to above the epicontinental, foreland shelf, and Nanushuk facies were deposited in nonmarine to relatively shallow marine environments.

The Nanushuk Formation is a potential reservoir unit for $\mathrm{CO}_{2}$ storage between 3,000- and 6,600-ft subsurface depths (fig. 11). The SAU boundary is defined by the 3,000-ft drilling depth from well penetrations (IHS Energy Group, 2010), regional subsurface correlations of Decker $(2007,2010)$, and the extent of the Nanushuk Formation mapped by Houseknecht and others $(2009 \mathrm{a}, \mathrm{b})$. The range of total storage-formation thickness for the reservoir unit was determined from well picks (IHS Energy Group, 2010) and regional seismic-reflection correlations (Houseknecht and others, 2009b). The thickness of the net-porous interval was determined by multiplying the gross stratigraphic thickness by a net-to-gross ratio of approximately 0.6 from regional subsurface correlations of Decker (2010) (see also Potter and Moore, 2003). Average reservoir porosity is between approximately 10 and 18 percent, and permeability ranges from 0.02 to $800 \mathrm{mD}$ (Huffman, 1985; Potter and Moore, 2003). Water-quality measurements indicate that formation waters are generally characterized by total dissolved solids concentrations in excess of $10,000 \mathrm{mg} / \mathrm{L}$, such that injection of $\mathrm{CO}_{2}$ into most portions of this $\mathrm{SAU}$ seems unlikely to pose any risk to a potential potable water source. The only potential for potable water appears to be along the far eastern portion of the SAU. Formation waters increase in salinity to the west across the SAU, such that $87 \pm 13$ percent of the SAU is likely to be too saline to be potable (Breit, 2002; Hanor and others, 2004; uncertainties reflect minimum to maximum possible percentages of saline groundwater in the SAU).

The minimum and most likely volumes of enclosed pore space were calculated from the product of (1) the minimum and most likely areas of Nanushuk Formation structural reservoir traps interpreted from closure area estimated for the Brookian topset assessment units of the USGS National Oil and Gas Assessment (NOGA) of the central North Slope, Alaska, by Bird and others (2005); (2) minimum and most likely measurements of net sandstone thickness within a buoyant trap (Bird and others, 2005); and (3) minimum and most likely measurements of porosity within buoyant traps (Bird and others, 2005). The maximum buoyant-trapping pore volume was calculated in a similar fashion using upper bounds on closure area (Bird and others, 2005) and upper bounds on net sandstone thickness and porosity described above. 


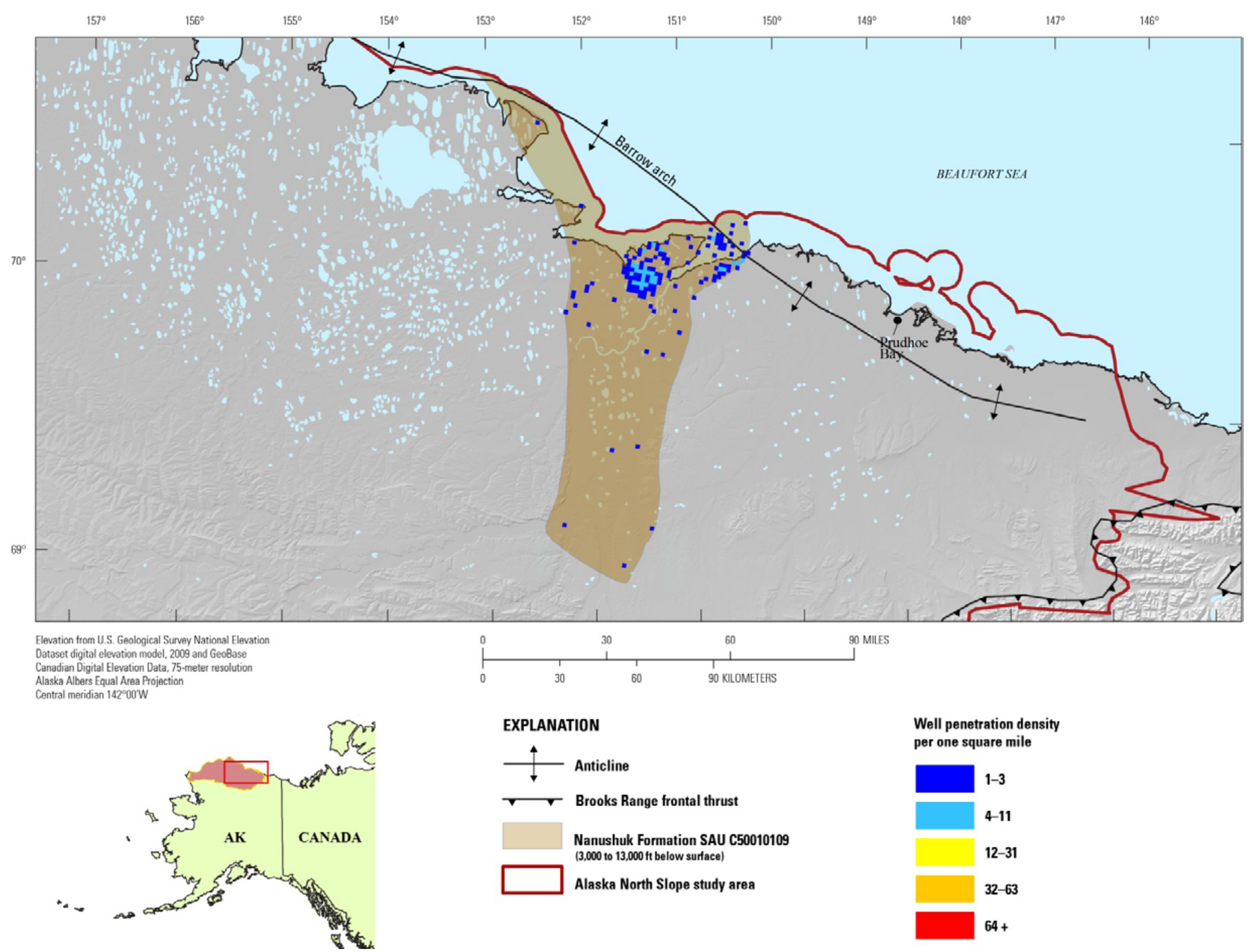

Figure 11. Map of the U.S. Geological Survey storage assessment unit (SAU) boundary for the Nanushuk Formation SAU (C50010109) in the Alaska North Slope study area. Grid cells (one-square mile) represent counts of wells, displayed at bottom-hole locations, derived from ENERDEQ well database (IHS Energy Group, 2011) that have penetrated the reservoir-formation top. The study area boundary was modified from Houseknecht and Bird (2006). 


\title{
Tuluvak Formation SAU C50010110
}

\author{
By William H. Craddock
}

The Cretaceous (Turonian and Coniacian) Tuluvak Formation (fig. 3) consists of nonmarine and shallow marine strata that were deposited during an episode of eastward progradation of nonmarine to shallow marine depositional systems across the Colville Basin (Houseknecht and Schenk, 2005). Deposition of the formation generally overlaps in time with extensional tectonism in the hinterland of the Brooks Range (Bird and Molenaar, 1992; Moore and others, 1994; Moore and others, 2004). The Tuluvak is confined to the central part of the North Slope, and from west to east, it progressively thins and fines across this region. Near the western limit of the formation, it is characterized by cobble to boulder conglomerate (Mull and others, 2003). To the east, conglomerates fine and interfinger with coal, shale, and compositionally and texturally mature sandstone. Near the eastern limit of the Tuluvak, it consists of fine- to medium-grained quartz arenite with low-angle cross bedding and various marine fossils (Mull and others, 2003; Houseknecht and Schenk, 2005). The Tuluvak was deposited in a variety of depositional environments, and generally following regional grain-size trends, depositional facies tend to transition from nonmarine in the west to shallow marine in the east (Mull and others, 2003). Specific depositional facies that are common to the unit include braided stream, marine deltaic, and shallow marine shoreface (for example, see Mull and others, 2003). Regional patterns in paleogeography and stratigraphic architecture and sandstone petrography suggest that the Tuluvak was sourced both from the ancestral Brooks Range to the south and from regions located to the west of the modern North Slope (Houseknecht and Schenk, 2005; Houseknecht and others, 2009a). The Tuluvak is capped by a flooding surface that is recognized around the central North Slope in seismic-reflection profiles and geophysical logs (Houseknecht and Schenk, 2005; Decker, 2007, 2010). Several hundred feet of fine-grained, marine strata of the lower part of the Schrader Bluffs Formation accumulated above this flooding surface, and these overlying strata should act as a robust seal for any prospective $\mathrm{CO}_{2}$ reservoirs.

Boundaries for the Tuluvak Formation SAU (fig. 12) were defined on the basis of 3,000-ft overburden contour (western boundary), a stratigraphic pinch-out that corresponds to the ultimate continental shelf edge during Tuluvak deposition (eastern boundary), and the frontal edge of the Brooks Range fold and thrust belt (southern boundary). The SAU spans depths of 3,000 to 5,200 $\mathrm{ft}$ and an area of 798,000 acres ( \pm 10 percent). A combination of data was used to constrain the structural architecture of the unit, including a database of 89 borehole penetrations (Kenneth Bird, USGS, written commun., 2007), stratigraphic correlations across the central North Slope (Decker, 2007, 2010), and regional seismic lines (for example, see Houseknecht and Schenk, 2005). In general, the formation dips at a low angle to the east across the central North Slope, and the SAU achieves its maximum depth along its eastern edge. The eastern boundary of the SAU was defined by the location of the ultimate Tuluvak continental shelf edge, which marks a transition from coarse-grained, shallow marine deposits to finegrained continental slope deposits. Although detailed analysis of geophysical logs and seismic-reflection profiles has been employed to define the position of the ultimate shelf edge for underlying, Lower Cretaceous clinothem sequences (for example, Houseknecht and others, 2009a; also, see discussion above), the position of analogous shelf edges for Upper Cretaceous rocks is less well defined. The shelfedge position was approximated using a combination of borehole penetrations, regional subsurface stratigraphic correlations, and the position of the Lower Cretaceous shelf edge (Kenneth Bird, USGS, written commun., 2007; Decker, 2007, 2010; Houseknecht and others, 2009a).

A gross formation-thickness isopach map was generated from a database of borehole stratigraphic information for the Tuluvak and underlying units (Kenneth Bird, USGS, written commun., 2007). The northern part of the formation ranges from about $400 \mathrm{ft}$ near the western SAU boundary to 
about $100 \mathrm{ft}$ near the shelf edge in the northeast (for example, see Decker, 2007, 2010). The formation appears to thicken to the south, to about $900 \mathrm{ft}$, based on analysis of geophysical logs from several boreholes. Across the SAU, mean gross-formation thickness appears to be about $600 \pm 100 \mathrm{ft}$. A net-togross ratio was estimated for the Tuluvak Formation SAU of 0.6 on the basis of geologic analogs from around the world (Doyle and Sweet, 1995; Escalona and Mann, 2006; Sixsmith and others, 2008) and evaluation of gamma ray, spontaneous potential, and resistivity logs for seven boreholes within the SAU (Decker, 2007, 2010), suggesting about $360 \pm 60 \mathrm{ft}$ of net sandstone, on average, across the SAU. Examination of core plugs from analogous Cretaceous strata suggests relatively low porosity in the unit in the target SAU depth with a regional average of between 10 and 20 percent (Huffman, 1985; Smosna, 1989), most likely about 15 percent. However, a database of oil reservoirs producing from Cretaceous rocks around the North Slope suggests that the regional average porosity of the formation may be somewhat higher (perhaps as high as 30 percent) (Nehring Associates, 2010). Perhaps because it contains a relatively high proportion of volcanic material, the formation generally exhibits relatively low permeabilities with typical values ranging from 0.1 to about $10 \mathrm{mD}$ (Huffman, 1985; Nehring Associates, 2010) and a most likely value of $1 \mathrm{mD}$. However, similar to other formations, the range of permeability exhibited by the formation varies over several orders of magnitude, including measured values as low as $0.05 \mathrm{mD}$ and as high as 1,000 mD (Huffman, 1985; Nehring Associates, 2010).

The formation does not appear to contain significant amounts of potable water, such that $\mathrm{CO}_{2}$ storage in this unit would involve little risk of contaminating a potential drinking-water source. A regional study of flow paths and salinity structure of groundwaters beneath the North Slope, based on interpretation of spontaneous potential logs, suggests that formation waters with TDS concentrations on the order of about 30,000 mg/L flow toward the SAU (Hanor and others, 2004). Direct measurements of groundwater salinity from nearby boreholes suggest the presence of formation water with salinity in excess of 20,000 mg/L (Breit, 2002). Nonetheless, the southern margin of the SAU is spatially associated with the frontal portion of the Brooks Range fold and thrust belt where Cretaceous strata outcrop. As such, there may be a potential for fresh water recharge in the southern part of the unit.

In order to assess the pore volume that may be accessible for $\mathrm{CO}_{2}$ storage in structural and (or) stratigraphic enclosures, we consulted a recent assessment of the potential for undiscovered hydrocarbon resources in the central North Slope (Bird and others, 2005). In this assessment, the size, abundance, thickness, and porosity of likely hydrocarbon traps were characterized within the central North Slope region. Minimum and most likely enclosed pore volume for the SAU were calculated from the product of (1) the minimum and most likely areas of Nanushuk Formation structural traps interpreted from closure area estimates for the Brookian topset assessment units in the central North Slope (Bird and others, 2005), (2) minimum and most likely measurements of net sandstone thickness within a buoyant trap (Bird and others, 2005), and (3) minimum and most likely measurements of porosity within buoyant traps (Bird and others, 2005). The maximum buoyant-trapping pore volume was calculated in a similar fashion using upper bounds on closure area (Bird and others, 2005) and upper bounds on average net sandstone thickness and porosity described above. The potential for $\mathrm{CO}_{2}$ sequestration in uncharged hydrocarbon traps is thought to be similar to previously described SAUs. 


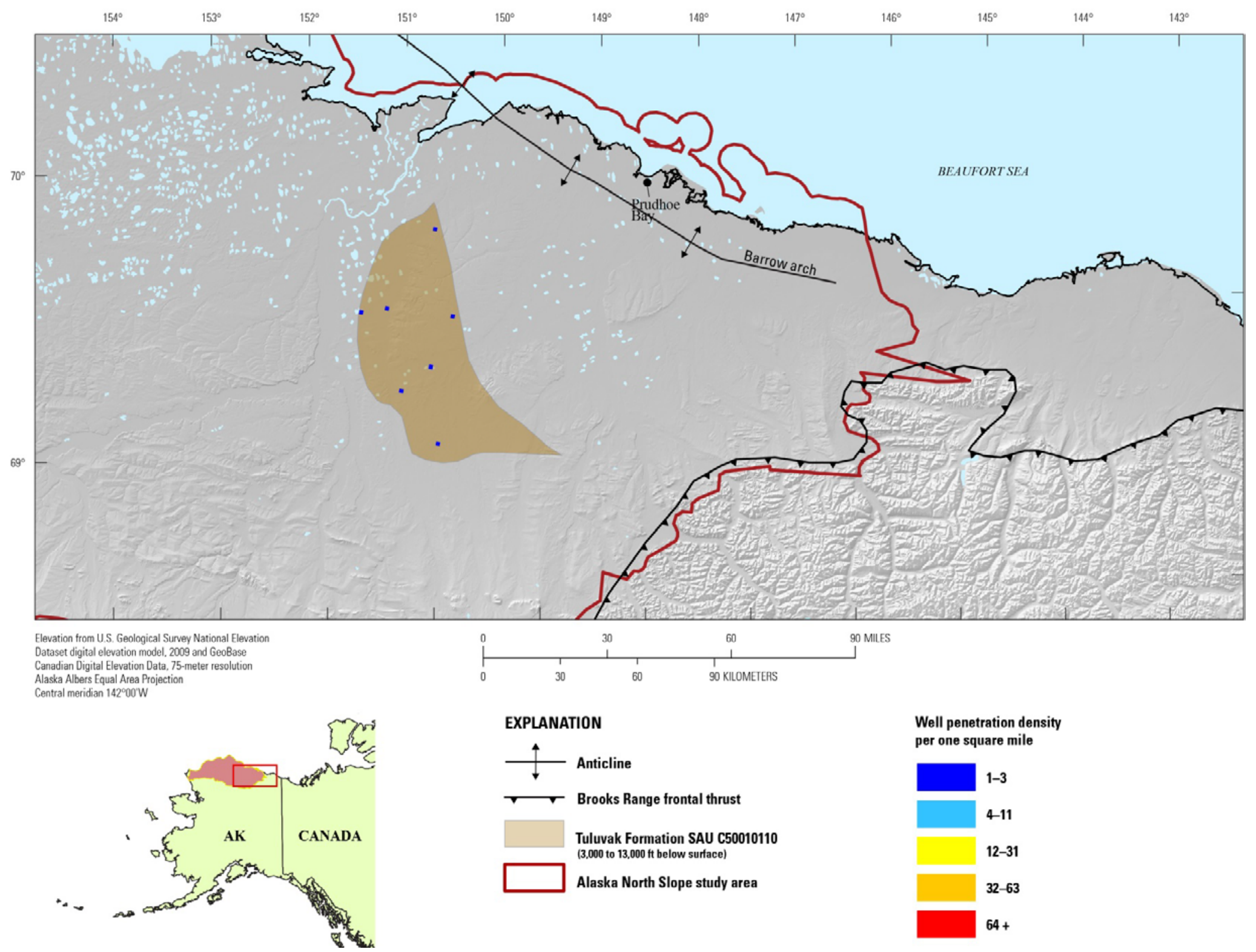

Figure 12. Map of the U.S. Geological Survey storage assessment unit (SAU) boundary for the Tuluvak Formation SAU (C50010110) in the Alaska North Slope study area. Grid cells (one-square mile) represent counts of wells, displayed at bottom-hole locations, derived from ENERDEQ well database (IHS Energy Group, 2011) that have penetrated the reservoir-formation top. The study area boundary was modified from Houseknecht and Bird (2006). 


\title{
Lower Seabee Formation SAU C50010111
}

\author{
By William H. Craddock
}

The lower part of the Seabee Formation (fig. 3) consists of continental slope and basin-floor strata that were deposited downdip of the Tuluvak continental shelf as depositional systems prograded across the Colville Basin during the Cenomanian to Coniacian (Bird and Molenaar, 1992; Moore and others, 1994; Mull and others, 2003; Houseknecht and Schenk, 2005). Similar to the Tuluvak Formation, the Seabee is confined to the central part of the Alaska North Slope region, and in general, it consists of mudstone, silty mudstone, and medium- to dark-gray to black, fissile, organic-matter-rich shale interbedded with thin tephras (Mull and others, 2003). The mudstones are interpreted to be fallout deposits that reflect deposition in continental slope and basin-floor settings, and they are thousands of feet thick (Mull and others, 2003; Decker, 2007, 2010). In the central-eastern Colville Basin, northeast of the ultimate Tuluvak shelf edge, fine-grained open-marine strata of the Seabee Formation are interbedded with thin siltstone and fine-grained sandstone strata that are informally referred to as the Bermuda interval. These coarser grained strata are interpreted as submarine continental-slope apron turbidites that accumulated during Turonian time (Decker, 2007). The Bermuda sandstone interval of the lower Seabee Formation is thought to represent recycled, coarse-grained material from the updip Tulvak continental shelf (Decker, 2007) because the interval is located in a relatively distal part of the Brookian foredeep, far from coarse-grained sediment sources. Due to the fact that the Bermuda interval of the lower Seabee Formation is encased within thick continental slope and basin-floor shale, any prospective $\mathrm{CO}_{2}$ reservoirs should have excellent topseals.

The lower part of the Seabee Formation slope-apron turbidites are buried by about 4,800 to $6,800 \mathrm{ft}$ of basin fill according to subsurface stratigraphic correlations (Decker, 2007, 2010), and the SAU boundaries are defined solely on the basis of the spatial distribution of sand-prone submarine fan facies in the subsurface (Decker, 2007, 2010) (fig. 13). The SAU spans an area of 207,000 acres $( \pm 10$ percent). The ultimate Tuluvak shelf margin was approximately northwest striking in the northcentral part of the Colville Basin, and the slope apron extends northeastward from this boundary over a distance of about 12 miles (Decker, 2007, 2010). The turbidite apron appears to be confined to a region that extends approximately $30 \mathrm{~km}$ from north to south along the Tuluvak shelf edge (Decker 2007, 2010). Although it seems possible that analogous turbidites exist to the north or southeast along the Tuluvak shelf edge, exploration for these units has not been fruitful.

The thickness of the unit was measured on the basis of regional stratigraphic correlations that extend across the SAU (Decker, 2007, 2010), and on average, gross formation thickness appears to be about $425 \pm 75 \mathrm{ft}$. Using a net-to-gross ratio estimated from analogs (Richards and Bowman, 1998) and gamma ray, spontaneous potential, and resistivity logs within the Bermuda interval (Decker, 2007, 2010), a mean net sandstone thickness of $210+40 /-35 \mathrm{ft}$ was estimated. Growing interest in the lower Seabee Formation as a petroleum exploration target has spurred intensive investigation of the petrophysical properties of the unit. The unit appears to be rich in lithic materials (Helmold and others, 2006). Numerous core-plug measurements of porosity suggest that reservoirs may exhibit porosity of anywhere from 10 to 25 percent (Helmold and others, 2006). Porosity appears to vary on the basis of the depositional element with the highest porosities found in channel deposits and depositional lobes and lower porosities found in channel levees and on the abyssal plain (Helmold and others, 2006) suggesting that, in aggregate, the average porosity of the unit is between 14 and 21 percent with a most likely value of 18 percent. Core-plug measurements of permeability vary over many orders of magnitude from as low as about $0.002 \mathrm{mD}$ to as high as about $300 \mathrm{mD}$ (Helmold and others, 2006). Modal permeability appears to be about $0.5 \mathrm{mD}$ (Helmold and others, 2006). The formation does not appear to contain significant amounts of potable water, such that $\mathrm{CO}_{2}$ storage in this unit would involve little risk of 
contaminating a potential drinking-water source. The potential for the existence of potable water was assessed following the methods used for the Tuluvak Formation. Although most data from the North Slope suggest that the formation is highly saline (with TDS concentrations much greater than $10,000 \mathrm{mg} / \mathrm{L}$ ) (Hanor and others, 2004), outcropping Cretaceous rocks along the Brooks Range front may be freshwater recharge zones that allow some fresh groundwater to reach the southern portion of the SAU. The pore space that is enclosed within structural and stratigraphic traps was calculated following the methods described for the Upper Torok Formation SAU using data from the Brookian clinoform assessment unit of Bird and others (2005). 


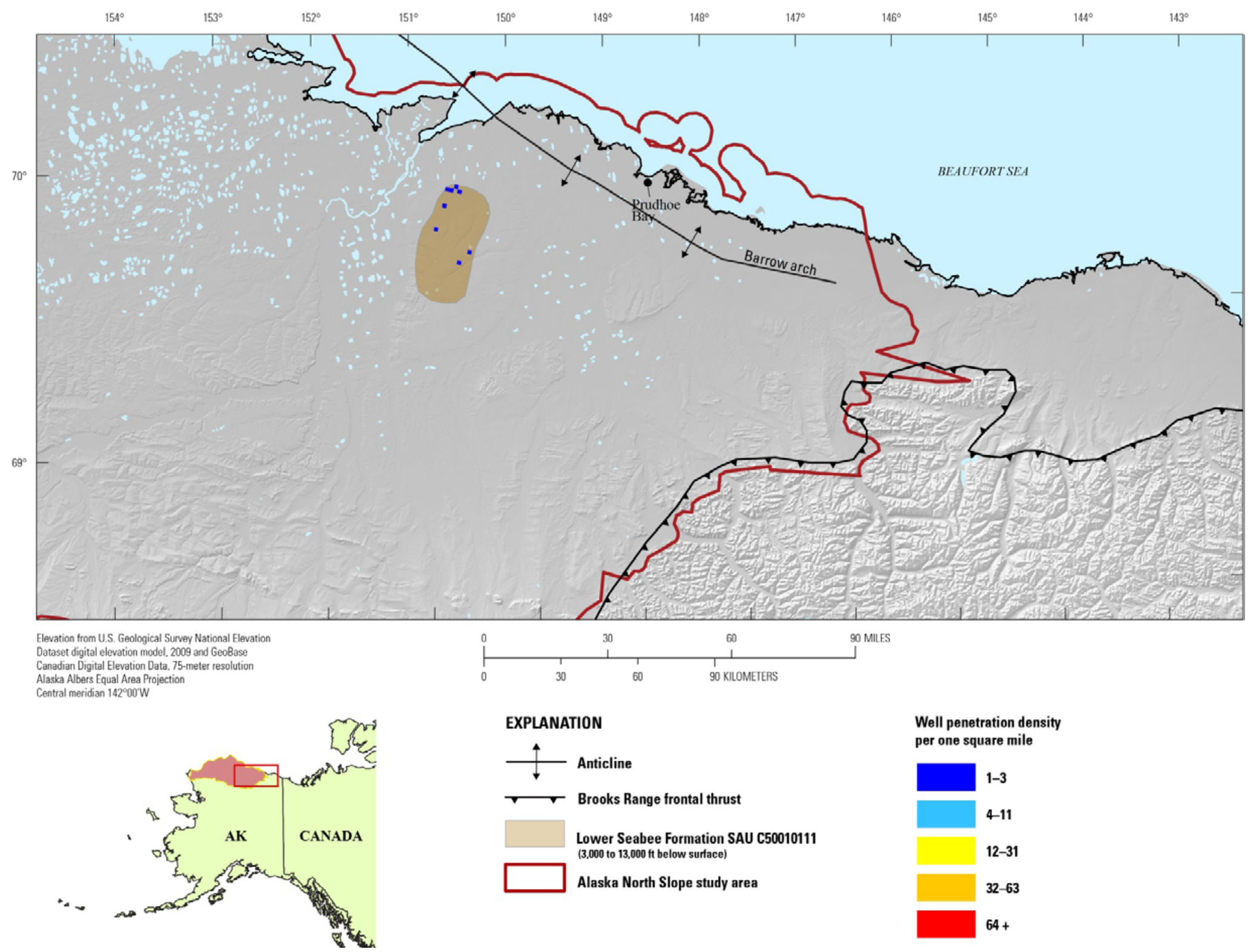

Figure 13. Map of the U.S. Geological Survey storage assessment unit (SAU) boundary for the Lower Seabee Formation SAU (C50010111) in the Alaska North Slope study area. Grid cells (one-square mile) represent counts of wells derived, displayed at bottom-hole locations, from ENERDEQ well database (IHS Energy Group, 2011) that have penetrated the reservoir-formation top. The study area boundary was modified from Houseknecht and Bird (2006). 


\title{
Middle Schrader Bluff SAU C50010112
}

\author{
By Ronald M. Drake II
}

The Upper Cretaceous Schrader Bluff Formation (fig. 3) of the Alaska North Slope has previously been divided into three formal members (Rogers Creek, Barrow Trail, and Sentinel Hill Members), which were abandoned and replaced by the informal lower, middle, and upper members by Mull and others (2003). This report will concentrate only on the middle member of the Schrader Bluff as a storage assessment unit because it is overlain by laterally extensive mudstone that likely will act as a seal. The middle Schrader Bluff is a shallow marine, proximal shelf deposit that overlies a middle Campanian disconformity or the Canning Formation where present (Decker, 2010). This unit is composed of progradational seismic-topset facies and records a regression in which the shoreline moved eastward toward the basin (Wartes and others, 2011). It is overlain by a transgressive flooding/ravinement surface and shelfal/platform shale and siltstone (Decker, 2010).

SAU boundaries for the Middle Schrader Bluff SAU (fig. 14) are based on projecting and delineating the top of the middle Schrader Bluff surface from cross sections and maps of Campanian shelf margins (Decker, 2010). Interpretations of well tops from commercial databases (IHS Energy Group, 2010) were considered; however, these data sources lacked the detail needed to make stratigraphic boundary determinations at a subformation level. The Middle Schrader Bluff SAU is confined between the mid-Campanian unconformity and the Campanian flooding surface as mapped by Decker (2010). The boundary for the Middle Schrader Bluff SAU includes the area where the top of the middle member of the Schrader Bluff is interpreted to be between 3,000 and 13,000 ft deep. Within the Middle Schrader Bluff SAU, gross thickness ranges from 50 to $150 \mathrm{ft}$ with net-porous-sand thicknesses of 30 to 90 feet and a median thickness of 60 feet ( 0.6 net-to-gross ratio). Water-quality data were compiled from various sources including oil and gas field summary tables (Wicks and others, 1991; Masterson and Eggert, 1992). Water-quality data are sparse for this interval; available data indicate that TDS concentrations are generally above $10,000 \mathrm{mg} / \mathrm{L}$. Porosity and permeability data were compiled from various sources including oil and gas field summary tables (Wicks and others, 1991; Masterson and Eggert, 1992), analogous formations described in Nelson (1999), and the Nehring Associates (2010) database. Average porosity for the Middle Schrader Bluff SAU is between 14 and 24 percent with a most likely value of 19 percent. Permeabilities for the Middle Schrader Bluff SAU range from 0.3 to $3,000 \mathrm{mD}$, and the mode is $50 \mathrm{mD}$.

The boundaries, thicknesses, rock properties, and water-quality information mentioned above were used in accordance with the USGS Carbon Sequestration Assessment Methodology to calculate the available storage space within the Middle Schrader Bluff SAU. 


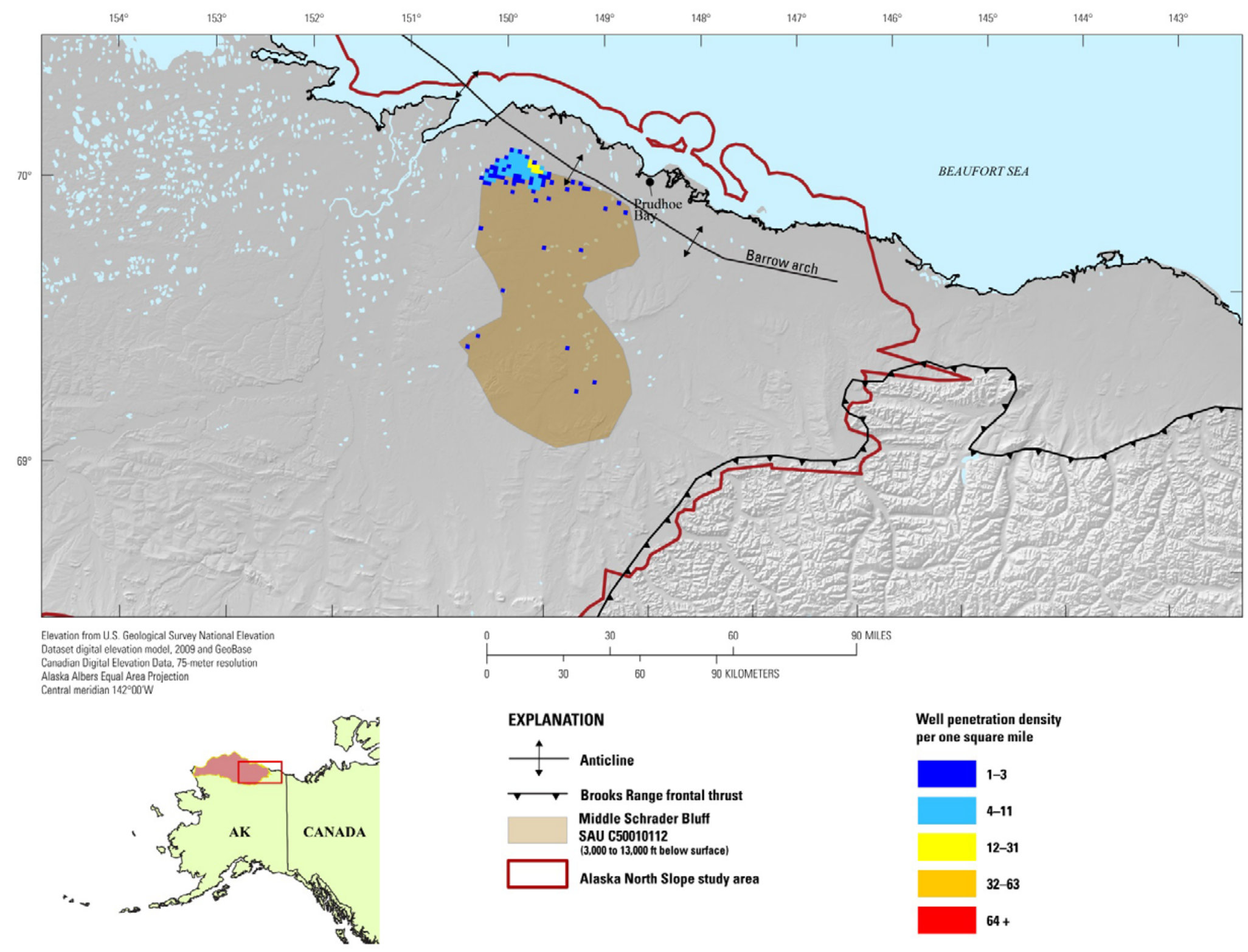

Figure 14. Map of the U.S. Geological Survey storage assessment unit (SAU) boundary for the Middle Schrader Bluff SAU (C50010112) in the Alaska North Slope study area. Grid cells (one-square mile) represent counts of wells derived, displayed at bottom-hole locations, from ENERDEQ well database (IHS Energy Group, 2011) that have penetrated the reservoir-formation top. The study area boundary was modified from Houseknecht and Bird (2006). 


\title{
Canning Formation SAU C50010113
}

\author{
By William H. Craddock
}

The Canning Formation (fig. 3) is a succession of continental slope and basin-floor strata that was deposited throughout the Late Cretaceous and Tertiary, during the later stages of the Brookian orogeny (Moore and others, 1994; Decker, 2007, 2010; also see Houseknecht and Schenk, 2005). The formation primarily consists of mudstone that accumulated downdip from the Upper Cretaceous to Neogene continental shelf successions of the Prince Creek, Schrader Bluff, and Sagavanirktok Formations (Decker, 2007, 2010; also see Houseknecht and Schenk, 2005). However, regional subsurface correlation of gamma ray, spontaneous potential, and resistivity logs indicate the presence of relatively coarse-grained lobes of material draped above the toes of several continental slope successions, and the stratigraphic context of these beds suggests that they are submarine slope-apron and (or) basin-floor fan-turbidite complexes (Decker, 2007, 2010). Due to the fact that coarse-grained slope-apron deposits are covered by thousands of feet of fine-grained continental slope strata, the turbidites should have a robust regional topseal.

The SAU boundaries are defined by the basinward (eastward, northward) limit of slope-apron and basin-floor fan turbidites and the 3,000-ft overburden contour (westward, southward). The SAU spans an area of 285,000 acres ( \pm 10 percent) and extends from 3,000- to 4,850-ft depth in the subsurface. The basinward limits of coarse-grained strata were approximated from regional subsurface correlations of geophysical logs (fig. 15) (Decker, 2007, 2010). For the purpose of this assessment, we confined our SAU to the lowermost Canning Formation submarine apron and turbidite fan because this appears to be the broadest and thickest of all the coarse-grained aprons in the Canning Formation. The overlying (younger) aprons are confined to spatially restricted regions (about a few miles in diameter), are only a few tens of feet thick, and are isolated from each other by miles of marine shale deposits. In contrast, the oldest Canning Formation apron extends over a region that is about 10 by 30 miles. The overburden contour map used to define the 3,000-ft overburden contour was constructed using a database of 181 borehole penetrations and regional subsurface stratigraphic correlations (Kenneth Bird, USGS, written commun., 2007; Decker, 2007, 2010). The SAU appears to achieve its maximum depth along its northwestern margin.

Regional stratigraphic correlations show that the formation ranges in thickness from about 800 to $80 \mathrm{ft}$ along the margins of fan complexes (Decker, 2007, 2010), and taken on a regional basis, gross formation thickness appears to be about $400 \pm 140 \mathrm{ft}$. Similar to the technique described for the lower part of the Seabee Formation, we used a net-to-gross ratio to determine a net sandstone thickness, and we estimate an average of about $200 \pm 70 \mathrm{ft}$ of net sandstone across the SAU. Analysis of core plugs from 15 boreholes and of petroleum production data suggests a wide range of porosity, from about 0 to 40 percent, but on average, porosity appears to be about 15 percent (Nehring Associates, 2010). Dozens of core-plug permeability measurements from each of four different wells suggest a most likely permeability for the Canning Formation of about $0.5 \mathrm{mD}$. Similar to most siliciclastic formations, permeability of core plugs varies over many orders of magnitude, from 0.01 to about $200 \mathrm{mD}$. The formation does not appear to contain significant amounts of potable water, such that $\mathrm{CO}_{2}$ storage in this unit would involve little risk of contaminating a potential drinking-water source. The potential for the existence of potable water was assessed following the methods used for the Tuluvak Formation. Although most data from the North Slope suggest that the formation has groundwaters with TDS concentrations that are greater than 10,000 $\mathrm{mg} / \mathrm{L}$ (Hanor and others, 2004), outcropping Cretaceous rocks along the Brooks Range front may be freshwater recharge zones that allow some fresh groundwater to reach the southern portion of the SAU. The pore space enclosed within structural and stratigraphic traps was calculated following the methods described for the Upper Torok Formation SAU using data from the Brookian clinoform assessment unit of Bird and others (2005). 


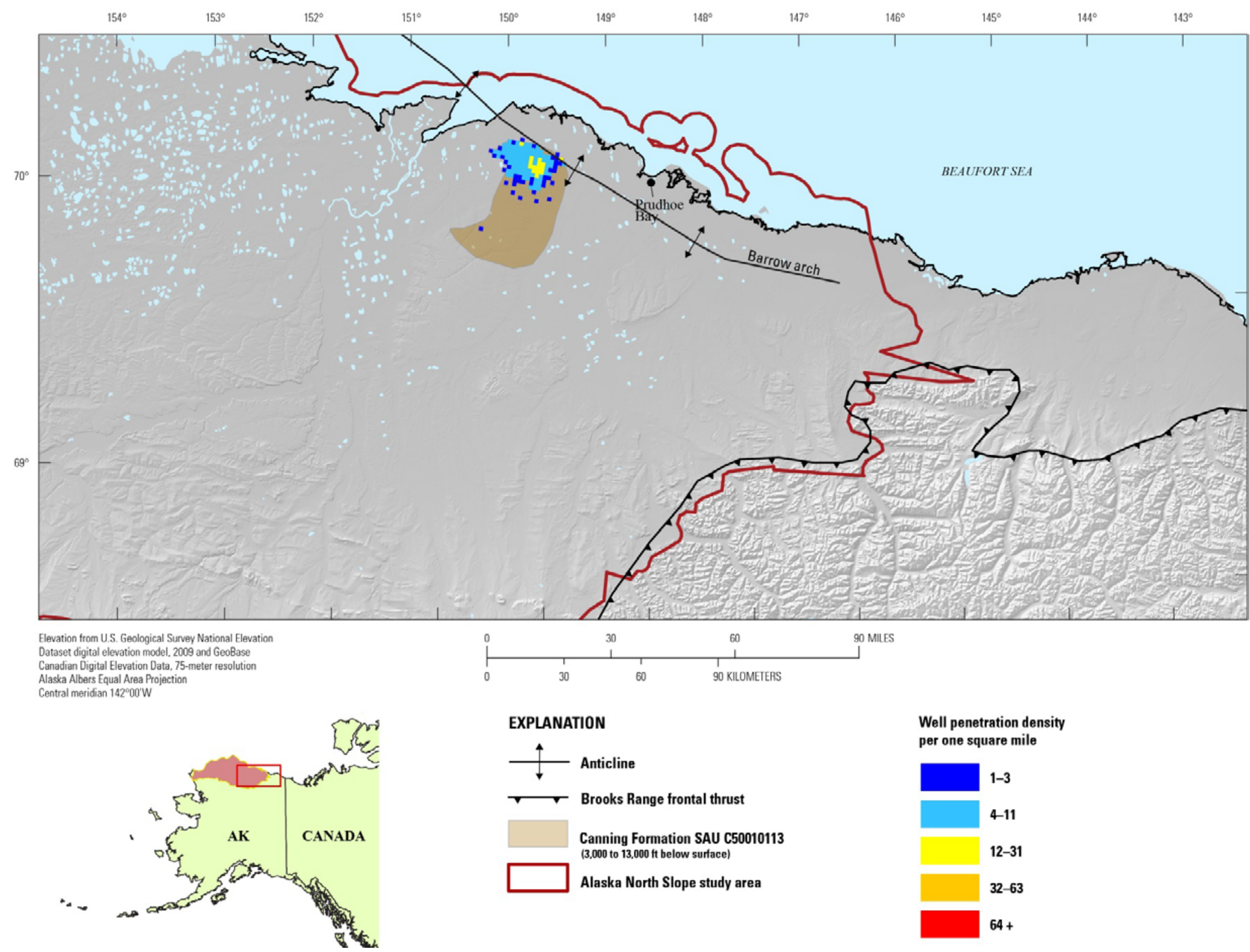

Figure 15. Map of the U.S. Geological Survey storage assessment unit (SAU) boundary for the Canning Formation SAU (C50010113) in the Alaska North Slope study area. Grid cells (one-square mile) represent counts of wells, displayed at bottom-hole locations, derived from ENERDEQ well database (IHS Energy Group, 2011) that have penetrated the reservoir-formation top. The study area boundary was modified from Houseknecht and Bird (2006). 


\title{
Staines Tongue SAU C50010114
}

\author{
By Ronald M. Drake II
}

The Staines Tongue of the Sagavanirktok Formation is late Paleocene to early Eocene in age (fig. 3) and overlies the Prince Creek Formation and underlies the Mikkelsen Tongue of the Canning Formation. The Staines Tongue consists of mostly progradational Paleocene seismic topset facies (Decker, 2010) that were deposited on a marine shelf and in associated deltaic and fluvial environments (Houseknecht and Schenk, 1999). The overlying Mikkelsen Tongue is a major transgressive deposit consisting of shale and minor sandstone that acts as a regional top seal.

SAU boundaries (fig. 16) for the Staines Tongue were defined on the basis of the 3-mile offshore limit and an overburden contour map that was generated from a borehole-penetrations database of the Brookian sequence (Kenneth Bird, USGS, written commun., 2007). The average depth to the top of the SAU is about 5,500 ft and the top of the SAU ranges from depths of 3,000 to 11,235 ft. Depths generally increase to the northeast.

The thickness of the SAU was assessed using an isopach map and generalized cross section of "Sequence D" as published by Houseknecht and Schenk (1999). A regional cross section by Decker (2010) indicates that the thickness of the Staines Tongue ranges from about 800 to 2,000 ft. According to Roberts and others (1992), the thickness varies from 650 to 2,950 ft. A borehole-penetrations database of the Brookian sequence (Kenneth Bird, USGS, written commun., 2007) also was utilized in determining SAU thickness. The most likely gross thickness of the SAU is between about 1,500 and $2,500 \mathrm{ft}$ across the SAU with a most likely thickness of 2,000 ft. In order to determine the most likely net thickness of porous strata within this interval, geophysical logs of the Staines Tongue (Flores and others, 2007) were analyzed. The average appears to be between 675 and 1,125 ft with a most likely average thickness of net-porous interval of $900 \mathrm{ft}$. A search of available literature (Nelson, 1999) regarding the porosity and permeability of the Staines Tongue indicated that the most likely porosity ranges from 13 to 23 percent with a most likely porosity of 18 percent. The permeability of the Staines Tongue ranges from 0.30 to $3,000 \mathrm{mD}$ with a mode of $50 \mathrm{mD}$. Sparse water-quality data for the Staines Tongue indicate that TDS concentrations generally are larger than 10,000 mg/L (Wicks and others, 1991; Masterson and Eggert, 1992; Hanor, 2004).

In order to estimate the maximum pore volume that is located within structural and stratigraphic traps, a compilation (Flores and others, 2007) showing the distribution of oil and gas fields was used to estimate potential area. The area used in our buoyant-trapping pore-volume calculations includes the area of all producing strata above and below the Staines Tongue Member and, as such, results in a potentially liberal estimate of maximum buoyant-trapping pore volume. 


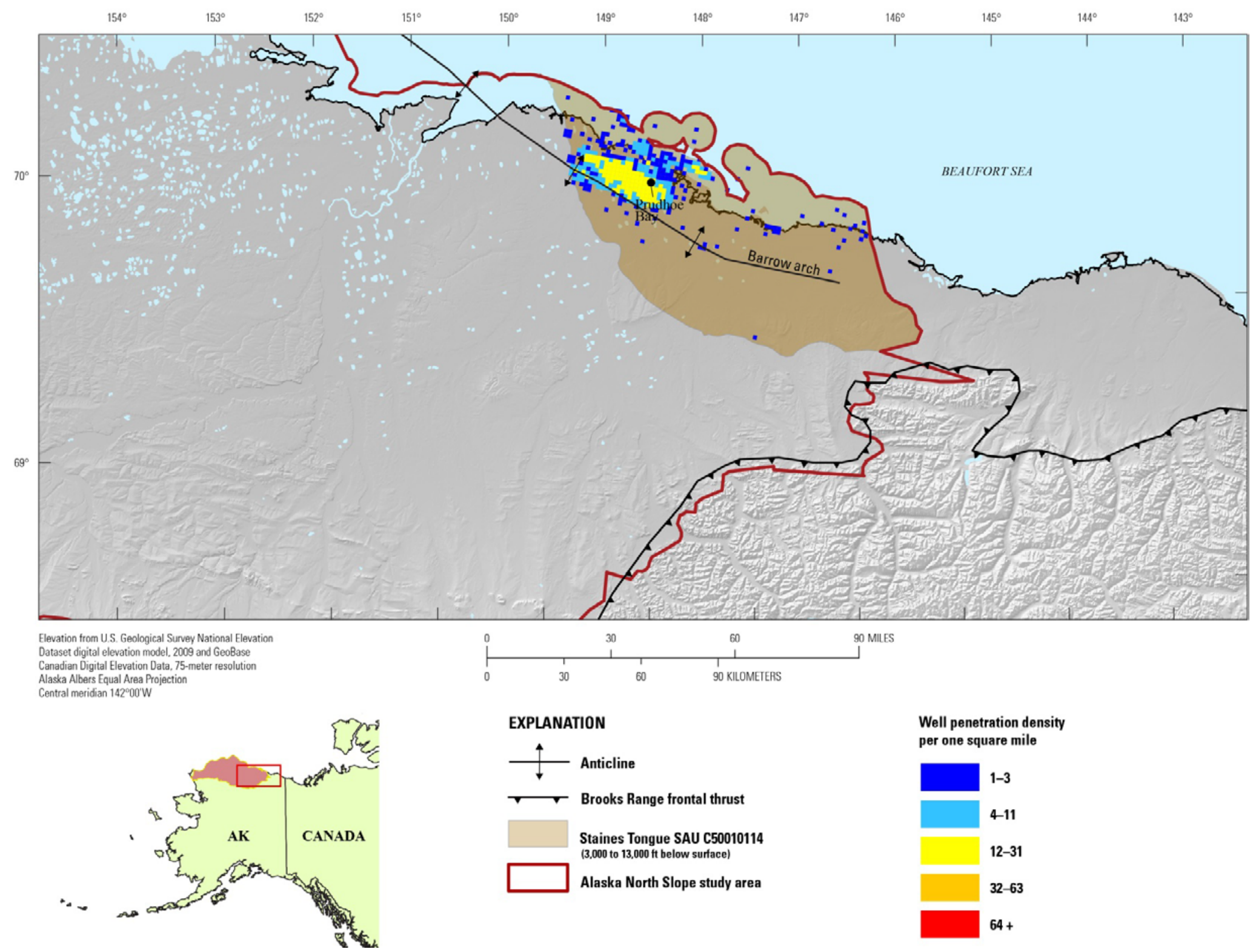

Figure 16. Map of the U.S. Geological Survey storage assessment unit (SAU) boundary for the Staines Tongue SAU (C50010114) in the Alaska North Slope study area. Grid cells (one-square mile) represent counts of wells, displayed at bottom-hole locations, derived from ENERDEQ well database (IHS Energy Group, 2011) that have penetrated the reservoir-formation top. The study area boundary was modified from Houseknecht and Bird (2006). 


\section{Kandik Basin, Alaska}

By Marc L. Buursink, Madalyn S. Blondes, Philip A. Freeman, Steven M. Cahan, Christina A. DeVera, and

Celeste D. Lohr

\section{Introduction}

\section{Basin Physiography}

The Kandik Basin, an extension of cratonic North America (Howell, 1995), is located in eastcentral Alaska and across the Canadian border in the Yukon Territory (fig. 17). The basin covers about 8,000 square miles $(4,942,107$ acres) with altitudes that range from about 2,000 to about 4,000 feet near the border in the Ogilvie Mountains and less toward the Yukon Flats to the west (Howell and others, 1992; Hannigan and others, 2000). The basin is mostly located in the United States (about 60 percent of the area), and its surface is covered by unnamed (in the U.S.) Mesozoic rocks. It comprises the catchments of the Kandik and Nation Rivers that empty into the Yukon River, which traverses the basin. The basin extends from the Yukon thrust zone on the northwest to the Tintina fault on the south with numerous Precambrian to Paleozoic outcrops surrounding it. The Kandik Basin sedimentary rocks are separated from crystalline igneous and metamorphic rocks to the south in the Yukon-Tanana upland by the translational Tintina fault (fig. 17) (Hannigan and others, 2000). This border fault is a linear trench containing Upper Cretaceous to lower Tertiary rocks whereas another, the Glenn Creek fault, simply bisects the basin (Howell and others, 1992; Dover, 1994).

The basin contains a nearly complete Paleozoic to Mesozoic section of the North American cordillera with a singular angular unconformity in the Carboniferous (Howell and Wiley, 1987; Lowell and others, 1966). Paleozoic rocks make up the majority of the basin and are approximately 15,000 ft thick (Popov and others, 2001). For additional details on Kandik Basin geology and Alaska tectonics, the reader is referred to Dover (1994), Foster and others (1994), and Plafker and Berg (1994). Interpretations and maps by Brabb and Churkin $(1967,1969)$, and the hydrocarbon assessments by Magoon (1993) and Howell (1995) also provide useful background.

\section{Geologic History}

The Kandik Basin rocks began accumulating during late Precambrian to Paleozoic continental rifting and subsidence (Howell and Wiley, 1987). The Late Devonian was defined by an orogenic pulse that may have coincided with a eustatic low-stand, followed by continental margin uplift in the Carboniferous and then renewed subsidence in the Permian and Triassic (Howell and Wiley, 1987). The neighboring Yukon Flats Basin evolved through crustal sag resulting from slip along the Tintina fault (fig. 17) and reflecting rotation of northern Alaska during the mid-Cretaceous about a pole located near the Mackenzie Delta (Howell and Wiley, 1987). Compressional tectonic deformation related to the Laramide orogeny produced structures that have potential for hydrocarbon trapping (Hannigan and others, 2000).

\section{Hydrocarbon Production and Exploration}

No hydrocarbons have been produced in the Kandik Basin. Nevertheless, organic shales and oil shows occur at multiple stratigraphic intervals from the Ordovician to the Triassic or Jurassic (Magoon and Kirschner, 1990). The Middle Triassic to Lower Cretaceous Glenn Shale is the richest organic shale and is partly equivalent to the Shublik Formation, a petroliferous interval in the Colville Basin of the Alaska North Slope (Howell, 1995). Three wells were drilled in the region during the 1970s: the Doyon 
number (no.) 1 well in the Kandik Basin, which reached total depth in Lower Cretaceous flysch and Jurassic rocks, and the Doyon nos. 2 and 3 wells in the Yukon Flats Basin, which reached total depth in Paleozoic limestone and dolomite. The Doyon no. 2 well was drilled through about 9,000 ft of Devonian sandstone and Devonian to Cambrian dolomite with a minor oil show reported near the bottom of the well (Magoon and Kirschner, 1990). The Doyon no. 3 well was drilled through about 13,500 ft of Devonian to Ordovician dolomite and limestone (Magoon and Kirschner, 1990). Because the Kandik Basin contains thrust faulting, the stratigraphic thicknesses may be uncertain. Structural trends observed in these wells strike generally northeasterly and appear to correlate regionally with the thrust belt in the neighboring Eagle Plain Basin in Canada (Magoon and Kirschner, 1990).

A USGS National Oil and Gas Assessment (NOGA) report by Magoon (1993) describes a cordilleran thrust play in the Kandik Basin and Yukon Flats region. The play involves thrust-faulted anticlines in both clastic and carbonate rocks of the Paleozoic, Mesozoic, and Tertiary (Magoon, 1993). Potential reservoirs in the play include (1) unnamed Cretaceous and Tertiary sandstone units, (2) the shallow marine Permian Tahkandit Limestone, (3) the carbonate turbidite Mississippian and Pennsylvanian Calico Bluff Formation, and (4) the turbidite sandstone Devonian Nation River Formation (Magoon, 1993). Reservoir properties are not known for these units, though potential oil accumulation sizes in this play were estimated in decreasing likelihood (in parenthesis) at $1 \mathrm{MMbbl}$ (100 percent), $200 \mathrm{MMbbl}$ (50 percent), and 1,000 MMbbl (1 percent) (Magoon, 1993). The more recent NOGA plays described by Howell (1995) consider younger Cretaceous formations, whereas the neighboring Yukon Flats NOGA assessment by Stanley and others (2004) describes Tertiary rocks that are younger than the rocks ultimately assessed here.

\section{Storage Resource Assessment}

The regional $\mathrm{CO}_{2}$ storage resource assessment of the Kandik Basin resulted in two SAUs, which are described in the following sections. The SAU name is typically based on the whole stratigraphic interval or formation(s) considered for storage (fig. 18). The geographic extents of the SAUs are defined by the depth to the top of the storage formation and by the geologic characteristics of the reservoir and the overlying regional seal. The geologic characteristics considered for each SAU include both the sealand reservoir-thickness distribution and the reservoir quality (such as net-to-gross ratio, porosity, and permeability). Furthermore, we attempt to identify regional trends in groundwater quality because the U.S. Environmental Protection Agency $(2009,2010)$ stipulates that aquifers with a total dissolved solids (TDS) concentration less than 10,000 parts per million $(\mathrm{mg} / \mathrm{L})$ may not be used for $\mathrm{CO}_{2}$ storage.

The assessment is conducted following the methodology of Burruss and others (2009), Brennan and others (2010), and Blondes and others (2013) (which prescribes the geologic model we follow), a probabilistic statistical analysis, and subsurface conditions favoring supercritical phase $\mathrm{CO}_{2}$. Subsurface conditions favoring $\mathrm{CO}_{2}$ storage at high density include relatively high basin pressures and temperatures (Buursink, 2012). Based on the methodology, we differentiate the assessed storage resource between residual trapping (typically larger but less certain) and buoyant trapping (typically smaller but more certain). Residual trapping occurs at the pore-scale, and buoyant trapping is analogous to stratigraphic and (or) structural hydrocarbon trapping. The minimum buoyant-trapping volume is determined from cumulative oil and gas production with the known hydrocarbon reserve volume, whereas the most likely buoyant-trapping volume adds the minimum volume and the estimated volume of undiscovered resources (Brennan and others, 2010; Hannigan and others, 2000; Magoon, 1993). The maximum buoyant resource is determined by the assessment geologist. Upon completion of the assessment, the following SAUs, listed by name and number in parentheses, are described: Nation River Formation SAU C50020101 and Step Conglomerate and Tahkandit Limestone SAU C50020102. 

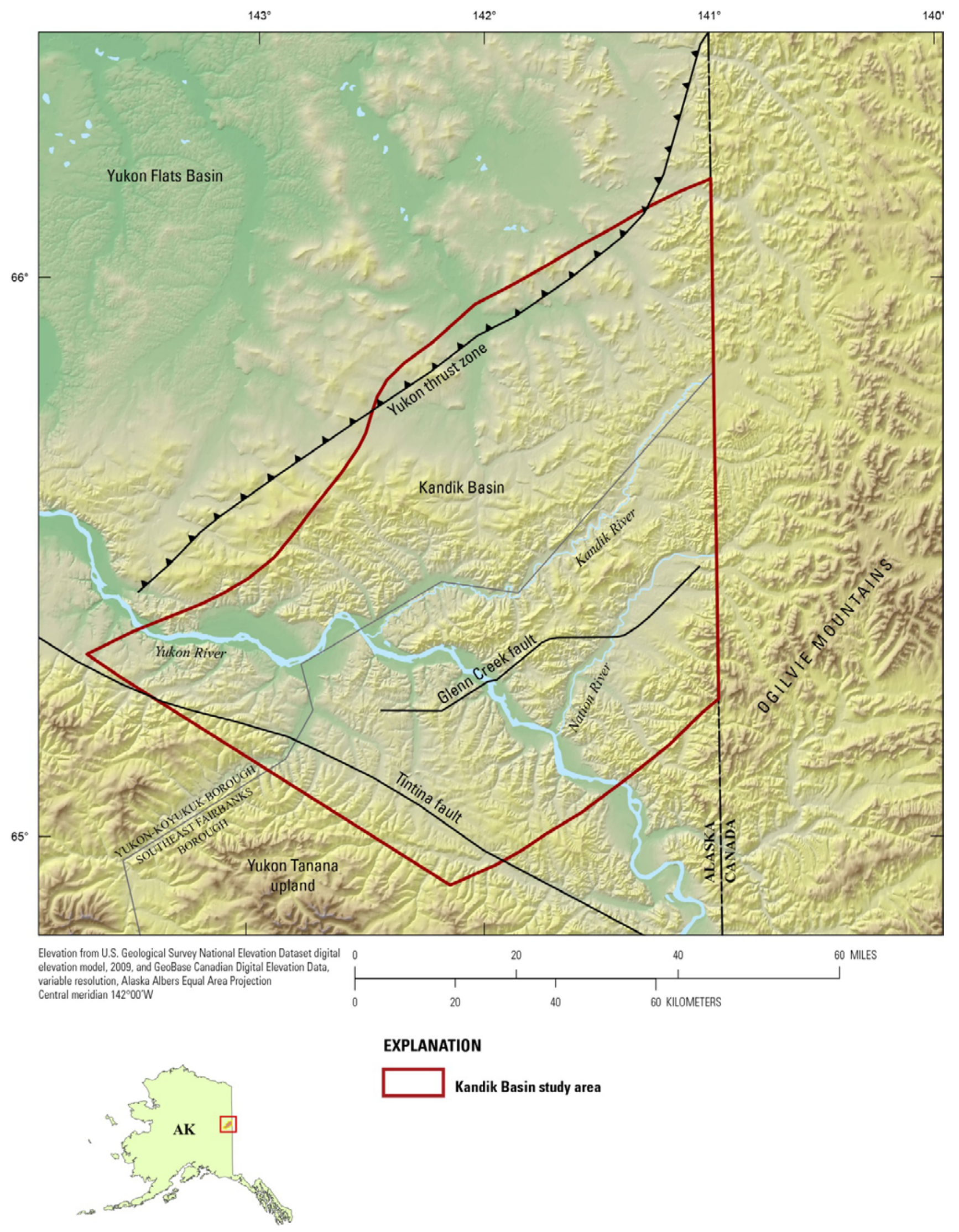

Figure 17. Map of the Kandik Basin, Alaska, study area. Included are major structural features and basin locations modified from Howell and Wiley (1987) and Hannigan and others (2000), and the study area boundary adapted from Magoon (1993). 


\begin{tabular}{|c|c|c|c|}
\hline System & Series & Stratigraphic unit & Storage Assessment Unit (SAU) notes \\
\hline Tertiary & & \multirow{2}{*}{$\begin{array}{l}\text { unnamed sandstone, mudstone, } \\
\text { and conglomerate }\end{array}$} & \\
\hline \multirow{4}{*}{ Cretaceous } & Upper & & \\
\hline & \multirow{3}{*}{ Lower } & $\begin{array}{c}\text { Kathul } \\
\text { Graywacke }\end{array}$ & \\
\hline & & $\begin{array}{c}\text { Biederman } \\
\text { Argillite }\end{array}$ & \\
\hline & & Keenan Quartzite & \\
\hline Jurassic & & \multirow{3}{*}{ Glenn Shale } & \multirow{3}{*}{$\begin{array}{l}\text { Step Conglomerate and Tahkandit Limestone SAU } \\
\text { C50020102 } \\
\text { Seal: Glenn Shale } \\
\text { Reservoir: Step Conglomerate and Tahkandit } \\
\text { Limestone }\end{array}$} \\
\hline \multirow{2}{*}{ Triassic } & Upper & & \\
\hline & Middle & & \\
\hline Permian & Lower & \begin{tabular}{c|r} 
Step & $\begin{array}{r}\text { Tahkandit } \\
\text { Limestone }\end{array}$
\end{tabular} & \\
\hline Pennsylvanian & Lower & . & \\
\hline \multirow{2}{*}{ Mississippian } & Upper & Calico Bluft formation & \\
\hline & Lower & Ford Lake Shale & \multirow{2}{*}{$\begin{array}{l}\text { Nation River Formation SAU } \\
\text { C50020101 } \\
\text { Seal: Ford Lake Shale } \\
\text { Reservoir: Nation River Formation }\end{array}$} \\
\hline Devonian & Upper & Nation River Formation & \\
\hline
\end{tabular}

Figure 18. Generalized stratigraphic column of geologic units in the Kandik Basin, Alaska, study area (modified from Magoon, 1993; Brabb, 1969). Storage assessment units (SAUs) consist of a reservoir or storage formation (red) and a regional seal (blue). Wavy lines indicate unconformable contacts, and gray areas represent unconformities or hiatuses. In some cases, not all subdivisions of units are shown. 


\title{
Nation River Formation SAU C50020101
}

\author{
By Marc L. Buursink
}

The Nation River Formation SAU consists of those portions of the preserved Upper Devonian clastic rocks deemed suitable as reservoir for $\mathrm{CO}_{2}$ sequestration and occurring beneath a regionally extensive seal (fig. 18). These storage-formation rocks comprise submarine fan facies, including mudstone, sandstone, and conglomerate (Howell and Wiley, 1987). The Nation River Formation is similar in lithology to widespread Upper Devonian Kanayut Conglomerate (Endicott Group) in the Brooks Range (Howell and Wiley, 1987). The overlying Upper Devonian to Upper Mississippian Ford Lake Shale is a gray-black siliceous shale and laminated gray-black chert, which is about 1,000 ft thick near the type section and about 2,000 ft thick 4 miles north (Brabb, 1969). Its stratigraphy and lithology are equivalent to the Kayak Formation (Endicott Group) in the Brooks Range (Richards and others, 1997). The Ford Lake Shale is considered a regional top seal for both Cretaceous and Paleozoic reservoirs in the petroleum resource assessment in Canada by Hannigan and others (2000).

SAU boundaries are typically defined by the depth of the storage-formation top. In this case, published Kandik Basin maps and cross sections that include the Nation River Formation help define the top of the storage formation. As expected from the minimal hydrocarbon exploration in the basin, no formation picks exist in the Kandik Basin as reported in our proprietary commercial database (IHS Energy Group, 2010). Generalized structural and geologic maps from Howell and Wiley (1987), Underwood and others (1989), Howell and others (1992), Johnsson (2000), and Hannigan and others (2000) and cross sections from Brabb and Grant (1971) and Van Kooten and others (1997) were used to help constrain the SAU boundaries (fig. 19). The Nation River Formation SAU occurs between 3,000 and 8,000 feet in depth and most likely has an area of about a 1.2 million acres . Measured sections by Laudon and others (1966) provided gross formation thickness; furthermore, these sections were interpreted to yield, along with analog references (Reading and Richards, 1994), net-to-gross estimates. These estimates were used to derive the net-porous thickness from the gross storage-formation thickness. The Nation River Formation SAU gross thickness ranges from 3,000 to 5,000 feet with a net thickness between 1,500 and 2,500 feet.

The Nation River Formation is not a productive hydrocarbon interval in the Kandik Basin, and no reservoir-quality data are reported in any form. Porosity inputs are derived from the Canadian Yukon Territory oil and gas assessment (Hannigan and others, 2000), North Slope data plots (Nelson and Kibler, 2003) for similar age formations, and global analog datasets (Ehrenberg and others, 2009). Estimates of porosity based on analysis of bulk density and sonic logs for the three regional wells using matching curves (Weatherford, 2009) yielded a complimentary range of values. Permeability results were based on North Slope data plots (Nelson and Kibler, 2003) for similar age formations and on analog datasets from a similar depositional environment (clastic submarine fan complex) (Martin and others, 1999). Ultimately, based on a review of the available results, the Nation River Formation SAU is assigned a porosity range from 4 to 15 percent, and the permeability ranges from 0.1 to $100 \mathrm{mD}$. No water-quality data were obtained for the Kandik Basin from published databases or other sources. Estimation of TDS from resistivity logs for the three regional wells using matching curves (Weatherford, 2009) showed water quality ranging from fresh to saline. Therefore, areas in the SAU where the groundwater TDS value is lower or higher than the U.S. Environmental Protection Agency underground source of drinking water (USDW) limit of $10,000 \mathrm{mg} / \mathrm{L}$ are undefined, a large uncertainty was assigned for this SAU.

To generate a probabilistic maximum volume for buoyant trapping for the SAU, results from the neighboring Canadian Yukon Territory oil and gas assessment (Hannigan and others, 2000) were used. Relative basin size and corresponding formations from the Canadian Yukon Territory assessment, which relied on U.S. outcrop mapping, were used as analogs. Because the Kandik Basin has no hydrocarbon production history, no local field location and size information is available. 

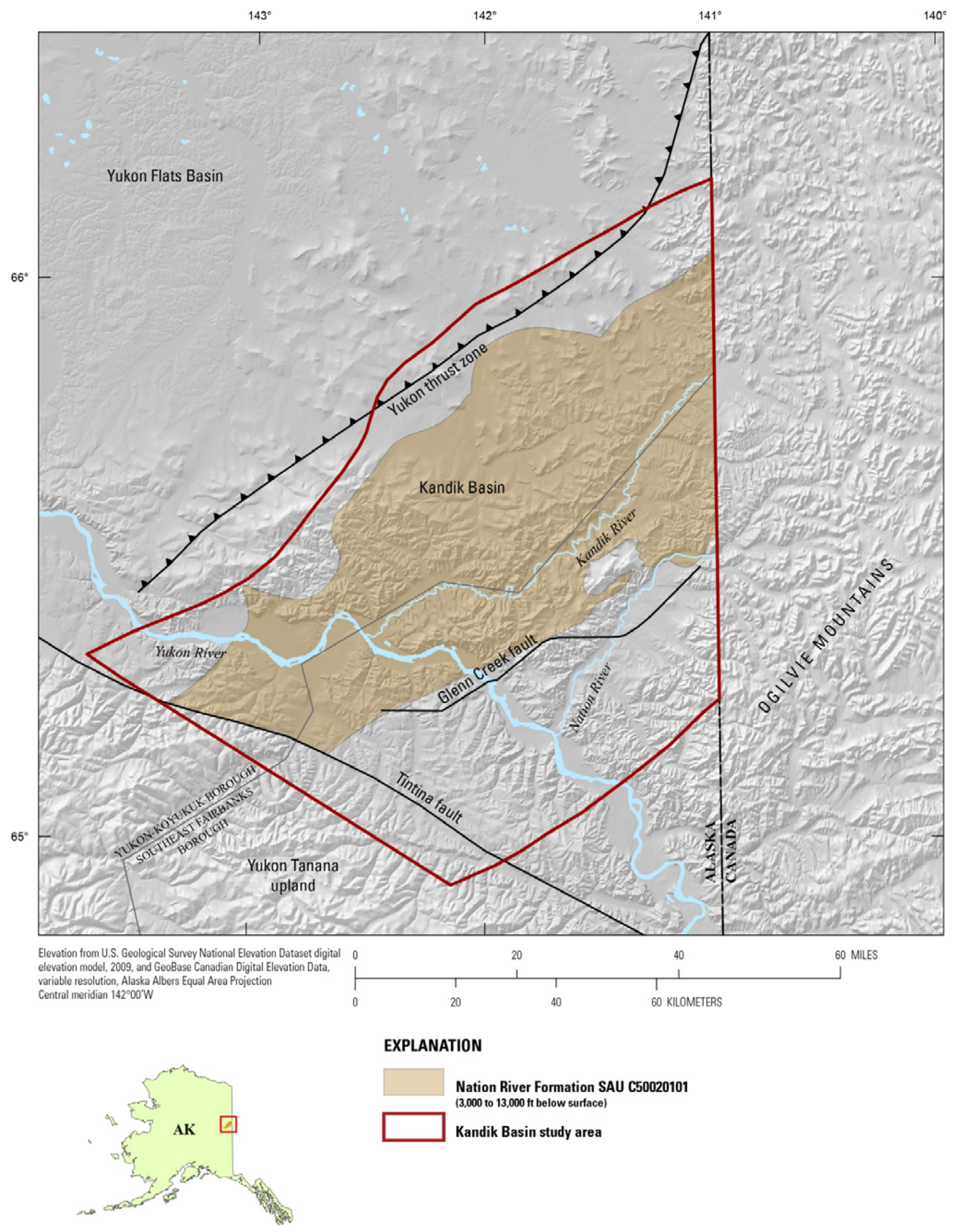

Figure 19. Map of the U.S. Geological Survey storage assessment unit (SAU) boundary for the Nation River Formation SAU (C50020101) in the Kandik Basin, Alaska, study area. The study area boundary was modified from Magoon (1993). 


\title{
Step Conglomerate and Tahkandit Limestone SAU C50020102
}

\author{
By Marc L. Buursink
}

The Step Conglomerate and Tahkandit Limestone SAU consists of those portions of the Lower Permian clastic and carbonate rocks deemed suitable as reservoir for $\mathrm{CO}_{2}$ sequestration that occur beneath a regionally extensive seal. The Step Conglomerate and Tahkandit Limestone are coeval, shallow Permian strata (fig. 18) (Brabb, 1969; Brabb and Grant, 1971). The overlying Triassic to Lower Cretaceous Glenn Shale (fig. 18) is mostly grayish-black, fissile carbonaceous shale that grades upward into black-gray, massive argillite, siltstone, and fossiliferous limestone (Brabb, 1969). The Glenn Shale is about 5,000 $\mathrm{ft}$ thick and is recognized over 2,000 $\mathrm{mi}^{2}$ (Brabb, 1969). The shale was deposited in a marine basin that persisted from the Permian to the Cretaceous (Brabb, 1969; Howell and Wiley, 1987).

SAU boundaries are typically defined by the depth of the storage-formation top. As expected from the minimal hydrocarbon exploration in the basin, no formation picks exist in the Kandik Basin as reported in our proprietary commercial database (IHS Energy Group, 2010). In this case, published Kandik Basin maps and cross sections with the Step Conglomerate and Tahkandit Limestone help define the top of the storage formation. Generalized structural and geologic maps from Howell and Wiley (1987), Underwood and others (1989), Howell and others (1992), Hannigan and others (2000), and Johnsson (2000) and cross sections from Brabb and Grant (1971) and Van Kooten and others (1997) were used to constrain the SAU boundary (fig. 20). The Step Conglomerate and Tahkandit Limestone SAU occurs between 3,000 and 6,000 feet in depth and most likely has an area of about a 1.2 million acres . Measured sections by Laudon and others (1966) provided gross formation thickness; furthermore, these sections were interpreted to yield, along with analog references (Reading and Richards, 1994), net-to-gross estimates. These estimates were used to derive the net-porous thickness from the gross storage-formation thickness. The Step Conglomerate and Tahkandit Limestone SAU gross thickness ranges from 1,500 to 2,500 feet with a net thickness between 750 and 1,200 feet.

The Step Conglomerate and Tahkandit Limestone are not productive hydrocarbon intervals in the Kandik Basin, and no reservoir-quality data are reported in any form. Porosity results are based on the neighboring Canadian Yukon Territory oil and gas assessment (Hannigan and others, 2000), North Slope data plots (Nelson and Kibler, 2003), and data tables (Clough, 1995) for similar age formations, as well as from global analog datasets (Ehrenberg and others, 2009). Estimation of porosity from bulk density and sonic logs for the three regional wells using matching curves (Weatherford, 2009) yielded a complimentary range of values. Permeability results were based on North Slope data (Clough, 1995; Nelson and Kibler, 2003) for similar age formations and from analog datasets (Ehrenberg and others, 2009). Ultimately, based on a review of the available results, the Step Conglomerate and Tahkandit Limestone SAU is assigned a porosity range from 4 to 15 percent and a permeability range from 0.1 to $1,000 \mathrm{mD}$. No water-quality data were obtained for the Kandik Basin from published databases or other sources. Estimation of TDS from resistivity logs for the three regional wells using matching curves (Weatherford, 2009) showed water quality ranging from fresh to saline. Therefore, the areas in the SAU where the groundwater TDS value is lower or higher than the U.S. Environmental Protection Agency USDW limit of 10,000 mg/L were undefined, a large uncertainty was assigned for this SAU.

To generate a probabilistic maximum volume for buoyant trapping for the SAU, results from the neighboring Canadian Yukon Territory oil and gas assessment (Hannigan and others, 2000) were used. Relative basin size and corresponding formations from the Canadian Yukon Territory assessment, which relied on U.S. outcrop mapping, were used as analogs. Because the Kandik Basin has no hydrocarbon production history, no local field location and size information are available. 


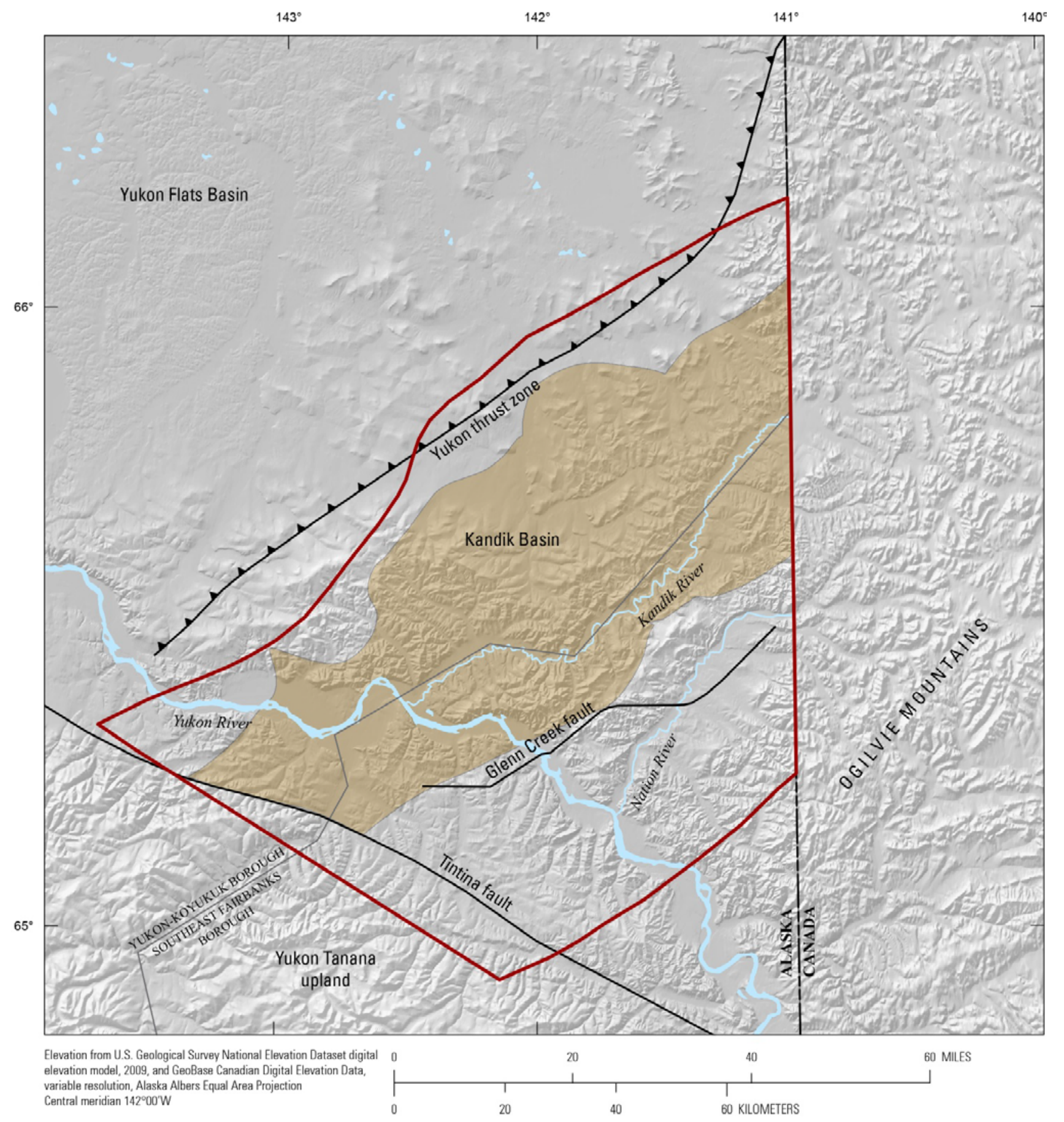

\section{EXPLANATION}
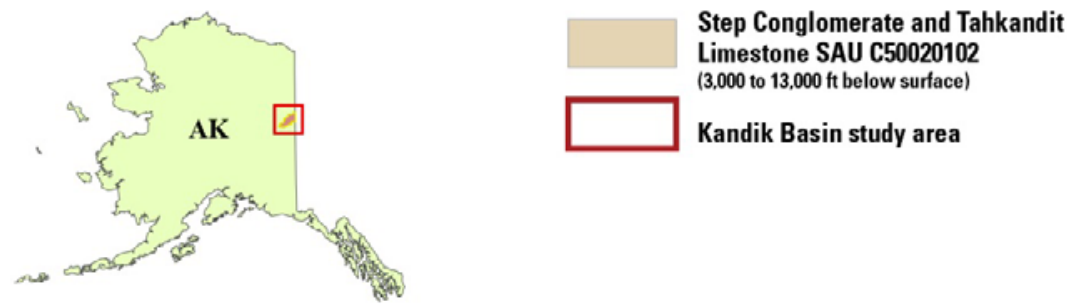

Figure 20. Map of the U.S. Geological Survey storage assessment unit (SAU) boundary for the Step Conglomerate and Tahkandit Limestone SAU (C50020102) in the Kandik Basin, Alaska, study area. The study area boundary was modified from Magoon (1993). 


\title{
Basins Not Assessed
}

Many sedimentary basins on the Alaskan continental shelves and within the continental interior were reviewed (fig. 1), and then discounted, as potential sites for geologic $\mathrm{CO}_{2}$ sequestration. Below, a brief geologic description for each of these basins is presented, as is a summary of the rationale for not conducting assessments in these basins. Most commonly, basins were discounted for geologic $\mathrm{CO}_{2}$ storage due to either (1) the apparent absence of (or inability to characterize) regional sealing formations with sufficiently large spatial extent, and (or) (2) the lack of reservoir-quality rock at depths in excess of 3,000 ft (see Burruss and others, 2009; Brennan and others, 2010; Blondes and others, 2013).

\section{Gulf of Alaska Basin}

\author{
Peter D. Warwick
}

The Gulf of Alaska Basin is located along the coastal plain and Alaska State waters areas of southeastern Alaska and contains several thousand feet of Cenozoic carbonate and siliciclastic sediments and sedimentary rocks (fig. 1) (Ehm, 1983; Plafker, 1987). No SAUs were defined in the Gulf of Alaska Basin, because no regional sealing formation could be identified in the basin stratigraphy. The area is also seismically active (Page and others, 1991) and may not be suitable for $\mathrm{CO}_{2}$ storage.

\section{Cook Inlet Basin}

\author{
Matthew D. Merill
}

The Cook Inlet Basin is an intermontane graben with a general north-northeast trend, and it is subparallel to its confining mountainous borders (fig. 1) (Kirschner and Lyon, 1973). Tertiary rocks of the basin were deposited in a nonmarine forearc-basin setting. Tertiary sedimentary rocks of note include tuffaceous conglomerates to siltstones of the West Foreland Formation, conglomeratic sandstones of the Hemlock Conglomerate, and various sandstones, siltstones, and shales from the Tyonek, Beluga, and Sterling Formations (Magoon, 1994).

In 2012, oil and gas production from the Cook Inlet was 10,000 barrels (oil and natural gas liquids) per day and 300 million cubic feet of gas per day (Alaska Department of Natural Resources, Division of Oil and Gas, 2012). Production data indicate that there are 60 large (at least $0.5 \mathrm{MMbbl}$ of oil or 3 trillion cubic feet of gas [TCFG]) currently active or historical fields in Cook Inlet, and they all produce from Tertiary stratigraphic units (Nehring Associates, 2010). The source rocks for these reservoirs are within the Middle Jurassic (174-164 Ma) Tuxedni Group (Magoon, 1994).

Tertiary strata in the basin have formed into an en échelon series of anticlines. Geologic $\mathrm{CO}_{2}$ sequestration may be possible locally within these structural highs, but these features alone do not justify conducting a $\mathrm{CO}_{2}$ sequestration capacity assessment (see Burruss and others, 2009; Brennan and others, 2010; Blondes and others, 2013). There are no known impermeable rocks with regional extent in the Cook Inlet overlying any of the Tertiary reservoir units. Although impermeable rocks may exist at greater depths (in Mesozoic strata), the interval has been minimally described, and the potential for regional sealing formations is unclear. 


\title{
Bristol Bay Basin
}

Ernie R. Slucher and Matthew D. Merrill

Bristol Bay Basin is a Cenozoic back-arc basin northwest of the Alaska Peninsula (fig. 1). Only a small portion of the basin, along the southeastern and northeastern basin margins, lies within the StateFederal waters boundary (Alaska Department of Natural Resources, Division of Oil and Gas, 2004b). More than 19,000 ft of Cenozoic age rocks occur in the basin axis (Finzel and others, 2009). Only 12 exploratory wells have been drilled throughout the Bristol Bay Basin, 11 of which are along the southeastern margin of the basin on the Alaska Peninsula (Alaska Department of Natural Resources, Division of Oil and Gas, 2004a). Records from these wells and surface-exposure studies indicate that the basin is dominated by nonmarine and marine siliciclastic sedimentary rocks interspersed with volcanic and volcanogenic clastic rocks.

Although reservoir and source (also potential sealing interval) rock intervals have been identified in the basin (Helmold and Brizzolara, 2005), the stratigraphy is divided only into large intervals at formation rank, each of which is thousands of feet thick and described in general terms only (Wilson and others, 1999; Alaska Department of Natural Resources, Division of Oil and Gas, 2004b). Moreover, geologic data in most of the basin are absent, and the current stratigraphic hierarchy lacks the resolution needed to identify specific intervals that could function as robust regional seals. In addition, the Bristol Bay region is in close proximity to active volcanoes and faults (Wesson and others, 2007; Alaska Volcano Observatory, 2013) related to the northwestward subduction of the Pacific plate beneath the North American plate and Alaska Peninsula. For these reasons, we did not conduct any assessments in Bristol Bay Basin.

\section{Bethel Basin}

\author{
William H. Craddock
}

Bethel Basin is a structural low located in southwestern Alaska (fig. 1), along the Bering Sea coast, near the mouths of the Yukon and Kuskokwim Rivers (see Mull and others, 1995). Geologic characterization of the basin is limited but comes from regional geologic mapping (Hoare, 1961; Mull and others, 1995, and references therein), aeromagnetic surveys (Dempsey and others, 1957), gravity surveys (Barnes, 1977), seismic-reflection profiling (see Mull and others, 1995), and an exploration well that was drilled to a depth of 14,890 ft (see Mull and others, 1995). The basin is floored by the Cretaceous Kuskokwim Group, which is a flysch succession that is distributed across broad swaths of southwestern Alaska, and regionally attains thicknesses in excess of 40,000 ft (Cady and others, 1955; Hoare, 1961). The flysch has been deformed and pervasively intruded by igneous rocks in the vicinity of Bethel Basin (see Box and others, 1993; Miller and Bundtzen, 1994; Mull and others, 1995 and references therein). Previous petroleum resource assessments in southwestern Alaska have ascribed poor reservoir quality to these rocks (Mull and others, 1995). In light of the limited characterization, apparent complexity, and probable low reservoir quality of the Kuskokwim Group, we did not attempt to assess the potential for $\mathrm{CO}_{2}$ storage within this stratigraphic interval. The Kuskokwim Group is overlain by Tertiary nonmarine strata. Regional gravity surveys have been interpreted to indicate that these strata are no thicker than about 2,000 ft in Bethel Basin (Barnes, 1977; Magoon and Kirschner, 1990); therefore, they are not suitable reservoir rocks within the context of this study. 


\title{
Kotzebue-Selawik Basin
}

\author{
Colin A. Doolan
}

The Kotzebue-Selawik Basin is located within the Kotzebue Sound and adjacent lowlands of northwestern Alaska (fig. 1). The basin is a fault-bounded, Tertiary depocenter consisting of pre-Neogene faults that remained active through the Pleistocene producing a horst and graben structural framework (Decker and others, 1989; Mason and others, 1997). Available subsurface data for the Kotzebue-Selawik Basin consist of log descriptions of two wells drilled by Standard Oil Company of California and one USGS seismic-reflection survey. This basin is floored by Proterozoic and Paleozoic schist and marble. The basement rocks are unconformably overlain by Eocene volcaniclastic rocks; Miocene and Pliocene interbedded sand, clay, and gravel beds of a marine transgression; upper Pliocene to lower Pleistocene nonmarine sand and gravel; and lower Pleistocene silt and mud from another marine transgression (Fisher, 1988; Neel, 1977).

Although the deepest part of the basin exceeds 15,000 ft, Miocene and younger marine transgressive units having suitable porosities for $\mathrm{CO}_{2}$ injection are typically shallower than $6,000 \mathrm{ft}$ (Decker and others, 1989). Furthermore, the lower Pleistocene shallow-marine transgressive unit, the only unit in the basin that may constitute an extensive, low-permeability sealing formation, is not known to exceed a 3,000-ft depth from surface; therefore, no SAUs could be defined within this basin.

\section{Copper River Basin}

\author{
Peter D. Warwick
}

The Copper River Basin, located in southeastern Alaska (fig. 1), contains a thick (up to about 3 mi), interbedded igneous, terrestrial, and marine basin-fill sequence that ranges in age from Mesozoic to Cenozoic (Ehm, 1983; Magoon and Kirschner, 1990; Fuis and others, 1991; Meyer, 2008). No SAUs were defined in the Copper River Basin, because no regional sealing formation could be identified in the basin stratigraphy.

\section{Susitna Basin}

\section{Ernie R. Slucher and Matthew D. Merrill}

The Susitna Basin, a Cenozoic rift-transtensional basin in south-central Alaska, is a northern extension of the Cook Inlet (fig. 1). The Castle Mountain fault separates the two basins. Several faults bisect the basin. The basin is in one of the most seismically active regions in the world, and several magnitude 6 or greater earthquakes are known to have occurred in the Susitna Basin area prior to 1964 (Haeussler and Plafker, 2003). Cenozoic strata that fill the basin consist mainly of cyclic deposits of coalbearing siliciclastic rocks deposited in estuarine and continental environments. Underlying Cretaceous and Jurassic units are sandstones and siltstones (volcanogenic in part) and shales deposited in marine environments. None of the formations in the basin contain an identifiable robust regional sealing unit as required by the USGS assessment methodology of Brennan and others (2010) and Blondes and others (2013); thus, the assessment team did not conduct a geologic $\mathrm{CO}_{2}$ assessment for the basin. 


\title{
Holitna, Minchumina, Nenana, and Ruby-Rampart Basins
}

\author{
Sean T. Brennan
}

Holinta, Michumina, Nenana, and Ruby-Rampart Basins are all located in the central Alaskan interior (fig. 1). The Holitna Basin spans many geologic terranes (LePain and others, 2000). Although stratigraphic successions of the various terranes may contain intervals that could serve as reservoirs or seals for carbon sequestration, abrupt changes in stratigraphy across terrane boundaries, as well as a lack of subsurface data, prevented defining a regional seal; therefore, the Holitna Basin was not assessed. The Michumina and Ruby-Rampart Basins are shallow basins that lack any subsurface characterization; however, they likely have no reservoir-seal pairs at depths in excess of 3,000 ft. The Nenana Basin, which may be as much as 25,000 to 30,000 ft deep (Van Kooten and others, 2012), has had only one well penetrate depths greater than about 4,000 ft deep, the Nunivak-1, which was drilled to a total depth of 11,075 ft (Van Kooten and others, 2012). The fluvial Healy Creek Formation and the overlying lacustrine Sanctuary Formation, both of the upper Eocene to Miocene Usibelli Group (Stanley and others, 1992; Ridgway and others, 2007), were evaluated as potential reservoir and seal intervals, respectively. However, the subsurface and outcrop character of these units did not appear to be highly prospective for geologic carbon sequestration, and in light of the limited geologic characterization of the basin, a geologic $\mathrm{CO}_{2}$ assessment was not conducted for this basin.

\section{Innoko Basin}

\author{
Colin A. Doolan
}

The Innoko Basin is located in a lowland area within the Kuskokwim Mountains (fig. 1) and is believed to have formed in the Late Cretaceous to early Tertiary (Bundtzen and others, 1987). The entire Cretaceous section in the basin is thought to exceed 8,000 ft in thickness and consists of a fining-upward sequence of turbidites, followed by prograding delta deposits, and finally nearshore shallow-marine deposits (Bundtzen and Laird, 1980). These Cretaceous strata were then intruded and overlain by Late Cretaceous to early Tertiary plutons and mafic extrusive rocks (Bundtzen and Laird, 1980; Bundtzen and others, 1987). Tertiary sedimentary units have not been identified within the basin.

Subsurface data for the Innoko Basin were not available at the time of this investigation, and surficial geology suggests that fine-grained, low-permeability sedimentary rocks that could act as effective seals are at the bottom of the Cretaceous sequence underlying any potential $\mathrm{CO}_{2}$ reservoirs. Furthermore, potential porous storage units have been intruded and covered by Late Cretaceous plutonic and volcanic deposits. Due to the poor quality of available storage units and complete lack of any regional sealing formations, the Innoko Basin was not assessed. 


\title{
Galena Basin
}

\author{
Colin A. Doolan
}

The Galena Basin of west-central Alaska (fig. 1) is bounded on the east and west by uplifted Cretaceous age rocks, on the north by an accreted Lower Cretaceous volcanic arc known as the Hogatza trend, and on the south by uplifted Paleozoic metamorphic rocks (Miller and others, 1959; Nilsen, 1989). Outcrops within the Galena Basin indicate that the Cretaceous strata could be several thousand feet thick (Stephenson and others, 2002). Tertiary strata have not been described within the basin, and the Cretaceous section is thought to be overlain by Quaternary sediments of the Yukon River (Miller and others, 1959; Stephenson and others, 2002).

Subsurface data for the Galena Basin are almost completely absent with one known water-well description that penetrated 360 feet of soft sediments near the city of Galena and one shallow seismic survey that was only sufficient to image the bedrock interface (Stephenson and others, 2002). The quality of porous reservoir units in the Galena Basin is largely unknown, and evidence of any lowpermeability sealing units that are regionally extensive across the basin is absent. Due to a lack of direct or indirect subsurface data, the Galena Basin was not assessed.

\section{Yukon-Koyukuk Basin}

\section{Colin A. Doolan}

The Yukon-Koyukuk Basin of west-central Alaska (fig. 1) is structurally complex and formed within a highly mobile volcanogenic belt of Cretaceous age flanked by pre-Cretaceous igneous and metasedimentary rocks (Cady, 1989; Patton, 1970). The stratigraphy of the mid-Cretaceous basin fill of the Yukon-Koyukuk Basin is inferred by surface geology and measured outcrop sections and can be divided into three gradational lithological units. These units include a thick turbidite sequence of volcanic graywacke and mudstone, a thinner marine shelf sequence of calcareous graywacke and mudstone, and a thick nonmarine and marine shelf sequence of sandstone, siltstone, and shale (Nilsen, 1989; Patton, 1970).

The strata in the Yukon-Koyukuk Basin are mainly mid-Cretaceous age and could be 20,000 ft thick or greater, based on measured sections at the basin margins (Nilsen, 1989; Patton, 1973). The turbidite and shelf facies sequences likely have adequate porosities at depth for the injection of $\mathrm{CO}_{2}$. However, the lithologic units do not appear to be laterally continuous across the basin with turbidite and deltaic facies deposited along the axis of the basin and shelf facies deposited closer to the basin margins (Nilsen, 1989). This lateral discontinuity leads to the conclusion that there would be no basin-wide sealing formations suitable for $\mathrm{CO}_{2}$ sequestration. Due to a lack of subsurface data and surface geology that suggests an absence of any regional sealing formations, the Yukon-Koyukuk Basin was not assessed. 


\title{
Kobuk Basin
}

\author{
Colin A. Doolan
}

The Kobuk Basin, located in the lowlands of the southern Brooks Range fold and thrust belt of north-central Alaska (fig. 1), lies within the Kobuk fault zone that began to form in the Early Jurassic and remained active through the mid-Tertiary (Avé Lallemant and others, 1998). The sedimentary strata of the Kobuk Basin are almost entirely mid- and Late Cretaceous age and consist of basal graywacke and mudstone turbidites overlain by fluvial and shallow-marine marginal conglomerates, sandstones, and shales (Patton and others, 1994; Nilsen, 1989).

Subsurface data for the Kobuk Basin were not available for this investigation, but surface geology suggests that the Cretaceous sedimentary units could be several thousand feet thick. Lowpermeability shale units are not known to be regionally extensive at any interval within the strata, and very little is known about the quality of both the porous and nonporous units within the basin. Because of the absence of basin-wide sealing formations and lack of information about the subsurface strata, the Kobuk Basin was not assessed.

\section{Yukon Flats Basin}

\section{Marc L. Buursink}

The Yukon Flats Basin is a broad alluvial lowland that straddles the Yukon River and lies south of the southeastern end of the Brooks Range and north of the Yukon-Tanana upland (fig. 1) (Magoon and Kirschner, 1990; Rowan and Stanley, 2008). The basin is bound on the west by the KokrineHodzana highlands and on the east by the Porcupine terrane (Kandik thrust belt), a hinterland segment of the cordilleran fold and thrust belt of Northwest Territories, Canada (Magoon and Kirschner, 1990). The basin is interpreted as a graben or half-graben complex and evolved through crustal sag from slip along the Tintina fault (reflecting rotation of northern Alaska during the mid-Cretaceous about a pole located near the Mackenzie Delta) (Howell and Wiley, 1987; Magoon and Kirschner, 1990).

Because well information from deeper than about 2,300 ft is not available, most of the Yukon Flats Basin subsurface geology has been inferred from (1) seismic-reflection profiles, (2) gravity and magnetic surveys, and (3) geological studies of shallow-basin core holes and regional outcrops (Rowan and Stanley, 2008). Nevertheless, the Yukon Flats Basin is one of the Cenozoic basins in east-central Alaska that have a set of common characteristics (Magoon, 1993). The characteristics relevant to this geologic carbon storage assessment are (1) the basin fill consists mainly of nonmarine fluvial and coalbearing sedimentary rocks deposited in numerous fining-upward sequences, (2) the basin depocenter for each younger deposit is commonly displaced as a result of deformation and uplift, and (3) the basin structure is commonly extensional, but folding related to thrust faulting is also interpreted (Magoon, 1993).

Though currently there is no commercial petroleum production in the Yukon Flats Basin, a recent USGS assessment describes the probable existence of technically recoverable oil and gas resources in Tertiary rocks. The USGS concluded that significant quantities of technically recoverable oil (estimated mean of about $173 \mathrm{MMbbl}$ ) and gas (estimated mean of about 5.5 TCFG) may be sourced from multiple shale, mudstone, and coal horizons (Stanley and others, 2004). Although the basin is filled with about 10,000 to $16,000 \mathrm{ft}$ of nonmarine Tertiary fill that may hold resources, the prospect for 
finding petroleum source rocks in the pre-Tertiary interval appears to be unlikely because these are mostly igneous and metamorphic (Magoon and Kirschner, 1990).

Consequently, no SAUs were identified in the Yukon Flats Basin for several reasons, including (1) the absence of a thick regional seal (typically marine shales), (2) extensional structural deformation in the basin that could lead to seal failure, (3) lack of interpreted and mapped regional storage formations from borehole penetrations below 3,000 ft, and (4) little interpreted reservoir rock in the preTertiary section.

\section{Acknowledgments}

We thank the West Coast Regional Carbon Sequestration Partnership and especially Lorraine Hwang (California Institute for Energy and Environment) for their help in supplying geologic information used in this review. We thank David Houseknecht (U.S. Geological Survey) for considerable consultation on Arctic Alaska. The authors would like to thank Troy Cook and Brian Valera for their additional database work on the Doyon wells. We also acknowledge help with Yukon Territory well data from the Geological Survey of Canada and from the Yukon Geological Survey. The content and presentation of this report benefited greatly from the technical reviews of David Houseknecht and William Rouse.

\section{References Cited}

Alaska Department of Natural Resources, Division of Oil and Gas, 2004a, Oil and gas well data for the Alaska Peninsula and Bristol Bay region: Alaska Department of Natural Resources, Division of Oil and Gas Poster Series 2004, http://dog.dnr.alaska.gov/Publications/Documents/AlaskaPeninsula/Maps/Oil_Gas_Well_Data_Brist ol_Bay_Alaska_Peninsula.pdf.

Alaska Department of Natural Resources, Division of Oil and Gas, 2004b, Regional geology for the Bristol Bay region and Alaska Peninsula: Alaska Department of Natural Resources, Division of Oil and Gas Poster Series 2004, http://dog.dnr.alaska.gov/Publications/Documents/AlaskaPeninsula/Maps/Regional_Geology_\%20Br istol_Bay_Alaska_Peninsula.pdf.

Alaska Department of Natural Resources, Division of Oil and Gas, 2006, Alaska oil and gas report, December 2005: Alaska Department of Natural Resources, Division of Oil and Gas, http://dog.dnr.alaska.gov/Publications/AnnualReports.htm.

Alaska Department of Natural Resources, Division of Oil and Gas, 2008, Regional geology of the North Slope of Alaska: Alaska Department of Natural Resources, Division of Oil and Gas Resource Series, Plate 2.

Alaska Department of Natural Resources, Division of Oil and Gas, 2012, Annual Report: Alaska Department of Natural Resources, Division of Oil and Gas, http://dog.dnr.alaska.gov/Publications/Documents/AnnualReports/2012_Annual_Report.pdf.

Alaska Volcano Observatory, 2013, Alaska Volcano Observatory Web site, http://avo.alaska.edu/. Avé Lallemant, H.G., Gottschalk, R.R., Sisson, V.B., and Oldow, J.S., 1998, Structural analysis of the Kobuk fault zone, north-central Alaska: Geological Society of America Special Paper 324, p. 261-268.

Barnes, D.F., 1977, Bouguer gravity map of Alaska: U.S. Geological Survey Geophysical Investigations Map GP-913, 1 sheet, scale 1:2,500,000.

Bird, K.J., 1999, Geographic and geologic setting, in The oil and gas resource potential of the 1002 Area, Arctic National Wildlife Refuge, Alaska: U.S. Geological Survey Open-File Report 98-34, $51 \mathrm{p}$. 
Bird, K.J., and Molenaar, C.M., 1987, Stratigraphy, in Bird, K.J., and Magoon, L.B., eds., Petroleum geology of the northern part of the Arctic National Wildlife Refuge, northeastern Alaska: U.S. Geological Survey Bulletin 1778, p. 37-59.

Bird, K.J., and Houseknecht, D.W., 1998, Arctic National Wildlife Refuge, 1002 Area, petroleum assessment, 1998, including economic analysis: U.S. Geological Survey Fact Sheet 0028-01, 6 p., http://pubs.usgs.gov/fs/fs-0028-01/fs-0028-01.pdf.

Bird, K.J., and Houseknecht, D.W., 2002, U.S. Geological Survey 2002 petroleum resource assessment of the National Petroleum Reserve in Alaska_-Play maps and technically recoverable resource estimates: U.S. Geological Survey Open-File Report 02-207, 19 p.

Bird, K.J., and Houseknecht, D.W., 2011, Geology and petroleum potential of Arctic Alaska, in Spencer, A.M., Embry, A.R., Gautier, D.L., Stoupakova, A.V., and Sørensen, K., eds., Arctic petroleum geology: Geological Society of London Memoir 35, p. 485-489.

Bird, K.J., Houseknecht, D.W., Attanasi, E.D., Moore, T.E., Nelson, P.H., Potter, C.J., Schenk, C.J., Schuenemeyer, J.H., Verma, M.K., Saltus, R.W., Phillips, J.D., Charpentier, R.R., Cook, T.A., Klett, T.R., Pollastro, R.M., 2005, Oil and gas assessment of central North Slope, Alaska, 2005: U.S.

Geological Survey Fact Sheet 2005-3043, 2 p., http://pubs.usgs.gov/fs/2005/3043/.

Blondes, M.S., Brennan, S.T., Merrill, M.D., Buursink, M.L., Warwick, P.D., Cahan, S.M., Cook, T.A., Corum, M.D., Craddock, W.H., DeVera, C.A., Drake, R.M., II, Drew, L.J., Freeman, P.A., Lohr, C.D., Olea, R.A., Roberts-Ashby, T.L., Slucher, E.R., and Varela, B.A., 2013, National assessment of geologic carbon dioxide storage resources-Methodology implementation: U.S. Geological Survey Open-File Report 2013-1055, 34 p.

Box, S.E., Moll-Stalcup, E.J., Frost, T.P., and Murphy, J.M., 1993, Preliminary geologic map of the Bethel and southern Russian Mission quadrangles, southwestern Alaska: U.S. Geological Survey Miscellaneous Field Studies Map MF-2226-A, 20 p., 1 sheet, scale 1:250,000.

Brabb, E.E., 1969, Mesozoic formations in east-central Alaska: Geological Survey Bulletin 1274-I, p. I1-I26.

Brabb, E.E., and Churkin, Michael, Jr., 1967, Stratigraphic evidence for the Late Devonian age of the Nation River Formation, east-central Alaska: U.S. Geological Survey Professional Paper 575-D, p. D4-D15.

Brabb, E.E., and Churkin, Michael, Jr., 1969, Age of Nation River Formation, east-central Alaska: The American Association of Petroleum Geologists Bulletin, v. 53, no. 2, p. 430-439.

Brabb, E.E., and Grant, R.E., 1971, Stratigraphy and paleontology of the revised type section for the Tahkandit Limestone (Permian) in east-central Alaska: U.S. Geological Survey Professional Paper 703, $26 \mathrm{p}$.

Breit, G.N., 2002, Produced waters database: U.S. Geological Survey online database, accessed March 23, 2011, at http://energy.cr.usgs.gov/prov/prodwat/.

Brennan, S.T., Burruss, R.C., Merrill, M.D., Freeman, P.A., and Ruppert, L.F., 2010, A probabilistic assessment methodology for the evaluation of geologic carbon dioxide storage: U.S. Geological Survey Open-File Report 2010-1127, 31 p., accessed March 22, 2011, at http://pubs.usgs.gov/of/2010/1127/.

Bundtzen, T.K., and Laird, G.M., 1980, Preliminary geology of the McGrath-Upper Innoko River area, western interior Alaska: Alaska Department of Natural Resources Open-File Report 134, p. 36.

Bundtzen, T.K., Cox, B.C., and Veach, N.C., 1987, Heavy mineral provenance studies in the Iditarod and Innoko districts, western Alaska: Alaska Division of Geological and Geophysical Surveys PublicData File 87-16, 25 p.

Burruss, R.C., Brennan, S.T., Freeman, P.A., Merrill, M.D., Ruppert, L.F., Becker, M.F., Herkelrath, W.N., Kharaka, Y.K., Neuzil, C.E., Swanson, S.M., Cook, T.A., Klett, T.R., Nelson, P.H., and Schenk, C.J., 2009, Development of a probabilistic assessment methodology for evaluation of carbon dioxide storage: U.S. Geological Survey Open-File Report 2009-1035, 81 p., accessed March 22, 2011, at http://pubs.usgs.gov/of/2009/1035/. 
Buursink, M.L., 2012, Reservoir pressure and temperature regimes in sedimentary basins and the geologic carbon-dioxide sequestration resource [abs]: AAPG Search and Discovery Article \#90142, in AAPG Annual Convention and Exhibition, Long Beach, Calif., April 22-25, 2012.

Cady, J.W., 1989, Geologic implications of topographic, gravity, and aeromagnetic data in the northern Yukon-Koyukuk Province and its borderlands, Alaska: Journal of Geophysical Research, v. 94, no. B11, p. 15821-15841.

Cady, W.M., Wallace, R.E., Hoare, J.M., and Webber, E.J., 1955, The central Kuskokwim region, Alaska: U.S. Geological Survey Professional Paper 268, 132 p., 5 sheets.

Clough, J.G., 1995, Porosity, permeability and grain density analyses of twenty Katakturuk Dolomite outcrop samples, northeastern Brooks Range, Alaska: Alaska Division of Geological \& Geophysical Surveys Public Data File 95-35, 12 p.

Coleman, J.L., Jr., and Cahan, S.M., 2012, Preliminary catalog of the sedimentary basins of the United States: U.S. Geological Survey Open-File Report 2012-1111, 27 p. (plus 4 figures and 1 table available as separate files), http://pubs.usgs.gov/of/2012/1111/.

Decker, J.F., Robinson, M.S., Clough, J.G., and Lyle, W.M., 1989, Geology and petroleum potential of Hope and Selawik Basins, offshore northwestern Alaska: Marine Geology, v. 90, p. 1-18.

Decker, P.L, 2007, Brookian sequence stratigraphic correlations, Umiat field to Milne Point field, westcentral North Slope, Alaska: Alaska Division of Geological and Geophysical Surveys Preliminary Interpretive Report, PIR 2007-2, 19 p., 1 sheet.

Decker, P.L., 2010, Brookian sequence stratigraphic framework of the northern Colville foreland basin, central North Slope, Alaska (poster and presentation), in DNR Spring Technical Review Meeting, Anchorage, April 21-22, 2010: Alaska Division of Geological \& Geophysical Surveys, 30 p., 1 sheet.

Decker, P.L., Wartes, M.A., Wallace, W.K., Houseknecht, D.W., Schenk, C.J., Gillis, R.J., and Mongrain, J., 2008, Stratigraphic and structural investigations in the Ivishak River and Gilead Creek areas-Progress during 2007: Alaska Division of Oil \& Gas, PIR 2008-1F, p. 55-83.

Dempsey, W.J., Meuschke, J.L., and Andreason, G.E., 1957, Profiles of Bethel Basin, Alaska: U.S. Geological Survey Open-File Map, 3 sheets, scale 1:250,000.

Dover, J.H., 1994, Geology of part of east-central Alaska, chap. 5 of Plafker, George, and Berg, H.C., eds., The geology of Alaska: Boulder, Colo., Geological Society of America, The Geology of North America, v. G-1, p. 153-161.

Doyle, J.D., and Sweet, M.L., 1995, Three-dimensional distribution of lithofacies, bounding surfaces, porosity, and permeability in a fluvial sandstone - Gypsy Sandstone of northern Oklahoma: American Association of Petroleum Geologists Bulletin, v. 79, no. 1., p. 70-96.

Dumoulin, J.A., Harris, A.G., Blome, C.D., and Young, L.E., 2004, Depositional settings, correlation, and age of Carboniferous rocks in the western Brooks Range, Alaska: Economic Geology, v. 99, p. $1355-1384$.

Dumoulin, J.A., Whalen, M.T., and Harris, A.G., 2006, Lithofacies, age, and sequence stratigraphy of the Carboniferous Lisburne Group in the Skimo Creek area, Central Brooks Range: U.S. Geological Survey Professional Paper 1739-B, 64 p.

Ehm, Arlen, 1983, Oil and gas basins map of Alaska: Alaska Division of Geological and Geophysical Surveys Special Report 32, 1 sheet, scale 1:2,500,000.

Ehrenberg, S.N., Nadeau, P.H., and Steen, Øyvind, 2009, Petroleum reservoir porosity versus depthInfluence of geological age: American Association of Petroleum Geologists Bulletin, v. 93, no. 10, p. 1281-1296.

Escalona, Alejandro, and Mann, Paul, 2006, Sequence-stratigraphic analysis of Eocene clastic foreland basin deposits in central Lake Maracaibo using high-resolution well correlation and 3-D seismic data: American Association of Petroleum Geologists Bulletin, v. 90, no. 4, p. 581-623.

Finzel, E.S., Ridgway, K.D., Reifenstuhl, R.R., Blodgett, R.B., White, J.M., and Decker, P.L., 2009, Stratigraphic framework and estuarine depositional environments of the Miocene Bear Lake 
Formation, Bristol Bay Basin, Alaska-Onshore equivalents to potential reservoir strata in a frontier gas-rich basin: American Association of Petroleum Geologists Bulletin, v. 93, no. 3, p. 379-405.

Fisher, M.A., 1988, Petroleum geology of the onshore part of Hope and Kotzebue Basins, Alaska-A report for the Federal Lands Assessment Program (FLAP): U.S. Geological Survey Open-File Report $88-383,5$ p.

Flores, R.M., Myers, M.D., Houseknecht, D.W., Stricker, G.D., Brizzolara, D.W., Ryherd, T.J., and Takahashi, K.I., 2007, Stratigraphy and facies of Cretaceous Schrader Bluff and Prince Creek Formations in Colville River Bluffs, North Slope, Alaska: U.S. Geological Survey Professional Paper $1748,52 \mathrm{p}$.

Foster, H.L., Keith, T.E.C., and Menzie, W.D., 1994, Geology of the Yukon-Tanana area of east-central Alaska, chap. 6 of Plafker, George, and Berg, H.C., eds., The geology of Alaska: Boulder, Colo., Geological Society of America, The Geology of North America, v. G-1, p. 205-240.

Fuis, G.S., Ambos, E.L., and Mooney, W.D., 1991, Crustal structure of accreted terranes in southern Alaska, Chugach Mountains and Copper River Basin, from seismic refraction results: Journal of Geophysical Research, v. 96, no. B3, p. 4187-4227.

Grantz, Arthur, and May, S.D., 1983, Rifting history and structural development of the continental margin north of Alaska, in Watkins, J.S., and Drake, C.L., eds., Studies in continental margin geology: American Association of Petroleum Geologists Memoir 34, p. 77-100.

Haeussler, P.J., and Plafker, George, 2003, Earthquakes in Alaska: U.S. Geological Survey Open-File Report 95-624, version 1.1, http://geopubs.wr.usgs.gov/open-file/of95-624/of95-624.pdf.

Hakkila, G.A., 1987, Twenty measured sections of Permian Echooka Formation, northeastern Brooks Range, Alaska: Department of Geoscience, University of Alaska Public-Data File 86-86k, 14 p.

Hannigan, P.K., Osadetz, K.G., Dixon, J., Bird, T., 2000, Petroleum resource assessment of the Kandik Basin, Yukon Territory, Canada: Oil and Gas Resources Branch, Department of Economic Development, Government of the Yukon, $73 \mathrm{p}$.

Hanor, J.S., Nunn, J.A., and Lee, Y., 2004, Salinity structure of the central North Slope foreland basin, Alaska, USA - Implications for pathways of past and present topographically driven regional fluid flow: Geofluids, v. 4, p. 152-168.

Helmold, K.P., and Brizzolara, D.W., 2005, Reservoir quality of Tertiary and Mesozoic sandstones, Bristol Bay Basin, Alaska: Alaska Department of Natural Resources, Division of Oil and Gas, http://dog.dnr.alaska.gov/Publications/Documents/AlaskaPeninsula/Maps/Bristol_Bay_Reservoir_ Quality_Montage.pdf.

Helmold, K.P., Campaign, W.J., Morris, W.R., Hastings, D.G., and Moothart, S.R., 2006, Reservoir quality and petrophysical model of the Tarn deep-water slope-apron system, North Slope, Alaska [abs.]: Geological Society of America Abstracts with Programs, v. 38, p. 16.

Hoare, J.M., 1961, Geology and tectonic setting of lower Kuskokwim-Bristol Bay region, Alaska: American Association of Petroleum Geologists Bulletin, v. 45, p. 594-611.

Houseknecht, D.W., and Bird, K.J., 2004, Sequence stratigraphy of the Kingak Shale (Jurassic-Lower Cretaceous), National Petroleum Reserve in Alaska: American Association of Petroleum Geologists Bulletin, v. 88, p. 279-302.

Houseknecht, D.W., and Bird, K.J., 2006, Oil and gas resources of the Arctic Alaska petroleum province: U.S. Geological Survey Professional Paper 1732-A, 11 p.,

http://pubs.usgs.gov/pp/pp1732/pp1732a/pp1732a.pdf.

Houseknecht, D.W., and Schenk, C.J., 1999, The oil and gas resource potential of the Arctic National Wildlife Refuge 1002 Area, Alaska, in ANWR Assessment Team, U.S. Geological Survey Open-File Report 98-34, chap. BS, 60 p., http://pubs.usgs.gov/of/1998/ofr-98-0034/BS.pdf.

Houseknecht, D.W., and Schenk, C.J., 2001, Depositional sequences and facies in the Torok Formation, National Petroleum Reserve-Alaska (NPRA), in Houseknecht, D.W., ed., NPRA core workshopPetroleum plays and systems in the National Petroleum Reserve-Alaska: SEPM Core Workshop 21, p. 179-199. 
Houseknecht, D.W., and Schenk, C.J., 2005, Sedimentology and sequence stratigraphy of the Cretaceous Nanushuk, Seabee, and Tuluvak Formations exposed on Umiat Mountain, north-central Alaska: U.S. Geological Survey Professional Paper 1709-B, http://pubs.usgs.gov/pp/pp1709b/.

Houseknecht, D.W., and Schenk, C.J., 2007, Outcrops of turbidite channel facies in the Torok Formation-Reservoir analogs for the Alaska North Slope, in Nilsen, T., Shew, R.D., Steffens, G.S., and Studlick, J.R.J., eds., An atlas of deepwater outcrops-Models and analogs: American Association of Petroleum Geologists, Geologic Studies 56, p. 373-377.

Houseknecht, D.W., Bird, K.J., and Schenk, C.J., 2009a, Seismic analysis of clinoform depositional sequences and shelf-margin trajectories in Albian strata, Alaska North Slope: Basin Research, v. 21, p. 644-654.

Houseknecht, D.W., LePain, D.L., Decker, P.L., and Schenk, C.J., 2009b, Lower Cretaceous clinoforms in Arctic Alaska-Core workshop: AAPG Energy Minerals Division and Alaska Geological Society, AAPG Annual Meeting Short Course No. 21A Notes, 80 p.

Houseknecht, D.W., Bird, K.J., Schuenemeyer, J.H., Attanasi, E.D., Garrity, C.P., Schenk, C.J., Charpentier, R.R., Pollastro, R.M., Cook, T.A., and Klett, T.R., 2010, 2010 Updated assessment of undiscovered oil and gas resources of the National Petroleum Reserve in Alaska (NPRA): U.S. Geological Survey Fact Sheet 2010-3102, 4 p.

Houseknecht, D.W., Bird, K.J., and Garrity, C.P., 2012, Assessment of undiscovered petroleum resources of the Arctic Alaska Petroleum Province: U.S. Geological Survey Scientific Investigations Report 2012-5147, 33 p.

Howell, D.G., 1995, Kandik Basin, in Stanley, R.G., Central Alaska Province (002), in Gautier, D.L., Dolton, G.L., Takahashi, K.I., and Varnes, K.L., eds., 1995 National assessment of United States oil and gas resources - Results, methodology, and supporting data: U.S. Geological Survey Digital Data Series DDS-30, Release 2, one CD-ROM, http://certmapper.cr.usgs.gov/data/noga95/prov2/text/prov2.pdf.

Howell, D.G., Johnsson, M.J., Underwood, M.B., Huafu, Lu, and Hillhouse, J.W., 1992, Tectonic evolution of the Kandik region, east-central Alaska-Preliminary interpretations, in Bradley, D.C., and Ford, A.B., eds., Geologic studies in Alaska by the U.S. Geological Survey, 1990: U.S.

Geological Survey Bulletin 1999, p. 127-140.

Howell, D.G., and Wiley, T.G., 1987, Crustal evolution of northern Alaska inferred from sedimentology and structural relations of the Kandik area: Tectonics, v. 6, no. 5, p. 619-631.

Hubbard, R.J., Edrich, S.P., and Rattey, R.P., 1987, Geologic evolution and hydrocarbon habitat of the "Arctic Alaska Microplate": Marine and Petroleum Geology, v. 4, no. 1, p. 2-34.

Huffman, A.C., Jr., ed., 1985, Geology of the Nanushuk Group and related rocks, North Slope, Alaska: U.S. Geological Survey Bulletin 1614, 129 p.

IHS Energy Group, 2010 [includes data current as of December 23, 2009], PIDM relational U.S. well data: IHS Energy Group; database available from IHS Energy Group, 15 Inverness Way East, D205, Englewood, CO 80112, U.S.A.

IHS Energy Group, 2011, ENERDEQ U.S. well data: IHS Energy Group; online database available from IHS Energy Group, 15 Inverness Way East, D205, Englewood, CO 80112, U.S.A. (accessed January 20, 2011).

Jameson, J., 1994, Models of porosity formation and their impact on reservoir description, Lisburne field, Prudhoe Bay, Alaska: American Association of Petroleum Geologists Bulletin, v. 78, no. 11, p. 1651-1678.

Johnsson, M.J., 2000, Tectonic assembly of east-central Alaska-Evidence from Cretaceous-Tertiary sandstones of the Kandik River terrane: Geological Society of America Bulletin, v. 112, no. 7 , p. 1023-1042.

Keller, M.A., Bird, K.J., and Evans, K.R., 1999, Petroleum source rock evaluation based on sonic and resistivity logs, of chap. SR, ANWR Assessment Team, The oil and gas resource potential of the 1002 
Area, Arctic National Wildlife Refuge, Alaska: U.S. Geological Survey Open-File Report 98-34, 62 p., http://pubs.usgs.gov/of/1998/ofr-98-0034/SR.pdf.

Kirschner, C.E., and Lyon, C.A., 1973, Stratigraphic and tectonic development of Cook Inlet petroleum province: Regional Arctic Geology of Alaska, v. 108, p. 396-407.

Kirschner, C.E., and Rycerski, B.A., 1988, Petroleum potential of representative stratigraphic and structural elements in the National Petroleum Reserve in Alaska, in Gryc, George, ed., Geology and exploration of the National Petroleum Reserve in Alaska, 1974-1982: U.S. Geological Survey Professional Paper 1399, p. 191-208.

Laudon, L.R., Hartwig, A.E., Morgridge, D.L., and Omernik, J.B., 1966, Middle and late Paleozoic stratigraphy, Alaska-Yukon border area between Yukon and Porcupine Rivers: American Association of Petroleum Geologists Bulletin, v. 50, no. 9, p. 1868-1889.

LePain, D.L., Blodgett, R.B., Clough, J.G., and Ryherd, T., 2000, Generalized stratigraphy and petroleum potential of the Holinta region, southwest Alaska: Alaska Division of Geological and Geophysical Surveys Preliminary Interpretative Report 2000-1, 23 p.

Lerand, M., 1973, Beaufort Sea, in McCrossan, R.G., ed., The future petroleum provinces of CanadaTheir geology and potential: Canadian Society of Petroleum Geology Memoir 1, p. 315-386.

Lowell, R.L., Hartwig, A.E., Morgridge, D.L., and Omernik, J.B., 1966, Middle and late Paleozoic stratigraphy, Alaska-Yukon border area between Yukon and Porcupine Rivers: American Association of Petroleum Geologists Bulletin, v. 50, no. 9, p. 1868-1889.

Magoon, L.B., 1993, in Powers, R.B., ed., Petroleum exploration plays and resource estimates, 1989, onshore United States_-Region 1, Alaska; Region 2, Pacific Coast: U.S. Geological Survey Bulletin 2034-A, 76 p.

Magoon, L.B., 1994, Tuxedni-Hemlock(!) Petroleum System in Cook Inlet, Alaska, U.S.A., chap. 22, part V, case studies-Western Hemisphere: AAPG Memoir 60, p. 359-370.

Magoon, L.B., and Kirschner, C.E., 1990, Alaska onshore national assessment program-Geology and petroleum resource potential of six onshore Alaska provinces: U.S. Geological Survey Open-File Report 88-450-T, 47 p., http://pubs.er.usgs.gov/publication/ofr88450T.

Martin, F.D., Kendall, R.P., Whitney, E.M., Hardage, B.A., Stubbs, B.A., Uszynski, Bruce, Weiss, W.W., 1999, Advanced reservoir characterization for improved oil recovery in a New Mexico Delaware Basin project, in Schatzinger, Richard, and Jordan, J.F., eds., Reservoir characterizationRecent advances: American Association of Petroleum Geologists Memoir 71, p. 93-108.

Mason, O.K., Hopkins, D.M., and Plug, L., 1997, Chronology and paleoclimate of storm-induced erosion and episodic dune growth across Cape Espenberg Spit, Alaska, U.S.A.: Journal of Coastal Research, v. 13, no. 3, p. 770-797.

Masterson, W.D., and Eggert, J.T., 1992, Kuparuk River field-U.S.A., North Slope, Alaska: American Association of Petroleum Geologists Special Publications, p. 257-284.

Meyer, J.F., Jr., compiler, 2008, Sedimentary basins and selected geology of interior Alaska: Alaska Department of Natural Resources, Division of Oil and Gas, Interior Alaska Oil and Gas Resource Series, 1 sheet, scale 1:1,000,000.

Miller, D.M., Payne, T.G., Gryc, G., 1959, Geology of possible petroleum provinces in Alaska: U.S. Geological Survey Bulletin 1094, p. 127.

Miller, M.L., and Bundtzen, T.K., 1994, Generalized geologic map of the Iditarod quadrangle, Alaska, showing potassium-argon, major oxide, trace element, fossil, paleocurrent, and archeological sample localities: U.S. Geological Survey Miscellaneous Field Studies Map MF-2219-A, one sheet, scale $1: 250,000,48 \mathrm{p}$.

Molenaar, C.M., 1983, Depositional relations of Cretaceous and lower Tertiary rocks, northeastern Alaska: American Association of Petroleum Geologists Bulletin, v. 67, no. 7, p. 1066-1080.

Moore, T.E., Wallace, W.K., Bird, K.J., Karl, S.M., Mull, C.G., and Dillon, J.T., 1994, Geology of northern Alaska, in Plafker, George, and Berg, H.C., eds., The geology of Alaska, v. G-1 of The geology of North America: Boulder, Colo., Geological Society of America, p. 49-140. 
Moore, T.E., Potter, C.J., O’Sullivan, P.B., Shelton, K.L., and Underwood, M.B., 2004, Two stages of deformation and fluid migration in the west-central Brooks Range fold and thrust belt, northern Alaska, in Swennen, R., Roure, F., and Granath, J.W., eds., Deformation, fluid flow, and reservoir appraisal in foreland fold and thrust belts: American Association of Petroleum Geologists Hedberg Series, no.1, p. 157-186.

Mull, C.G., Bundtzen, T.K., and Reifenstuhl, R.R., 1995, Hydrocarbon potential of the lower Kuskokwim River area, Yukon-Kuskokwim Delta, southwest Alaska: Alaska Division of Geological and Geophysical Surveys Public Data File 95-28, 34 p.

Mull, C.G., Houseknecht, D.W., and Bird, K.J., 2003, Revised Cretaceous and Tertiary stratigraphic nomenclature in the east-central Colville Basin, northern Alaska: U.S. Geological Survey Professional Paper 1673, 51 p., http://pubs.usgs.gov/prof/p1673/.

Neel, T.H., 1977, Both onshore and offshore Alaska hold vast exploration potential: Oil \& Gas Journal, v. 75, p. 198-202.

Nehring Associates, 2010 [data current as of December 2008], The significant oil and gas fields of the United States: Colorado Springs, Colo., Nehring Associates, Inc.; database available from Nehring Associates, Inc., P.O. Box 1655, Colorado Springs, CO 80901, U.S.A.

Nelson, P.H., 1999, Petrophysical properties, in ANWR Assessment Team, The oil and gas resource potential of the 1002 Area, Arctic National Wildlife Refuge, Alaska: U.S. Geological Survey OpenFile Report 98-34, chap. PP, 64 p., http://pubs.usgs.gov/of/1998/ofr-98-0034/PP.pdf.

Nelson, P.H., and Kibler, J.E., 2003, A catalog of porosity and permeability from core plugs in siliciclastic rocks: U.S. Geological Survey Open-File Report 03-420, 7 p., http://pubs.usgs.gov/of/2003/ofr-03-420/ofr-03-420.html.

Nilsen, T.R., 1989, Stratigraphy and sedimentology of the mid-Cretaceous deposits of the YukonKoyukuk Basin, west-central Alaska: Journal of Geophysical Research, v. 94, no. B11, p. 15925-15940.

Page, R.A., Biswas, N.N., Lahr, J.C., Pulpan, H., 1991, Seismicity of continental Alaska, in Slemmons, B., Engdahl, E.R., Zoback, M.D., and Blackwell, D.D., eds., Neotectonics of North America: Boulder, Colo., Geological Society of America, Decade Map, v. 1 p. 47-68.

Patton, W.W., Jr., 1970, Petroleum possibilities of the Yukon-Koyukuk Province, Alaska: U.S. Geological Survey Open-File Report 70-257, 15 p.

Patton, W.W., Jr., 1973, Reconnaissance geology of the northern Yukon-Koyukuk Province, Alaska: U.S. Geological Survey Professional Paper 774-A, 16 p.

Patton, W.W., Jr., Box, S.E., Moll-Stalcup, E.J., and Miller, T.P., 1994, Geology of west-central Alaska, in Plafker, George, and Berg, H.C., eds., The geology of Alaska: Boulder, Colo., Geological Society of America, The Geology of North America, v. G-1, p. 241-269.

Pessel, G.H., and Tailleur, I.L., 1978, Generalized isopach map of the Echooka Formation, eastern North Slope petroleum province, Alaska: U.S. Geological Survey Miscellaneous Field Studies Map MF-928-R, scale 1:500,000.

Plafker, George, 1987, Regional geology and petroleum potential of the northern Gulf of Alaska continental margin, in Scholl, D.W., Grantz, Arthur, Vedder, J.G., eds., Geology and resource potential of the continental margin of western North America and adjacent ocean basins-Beaufort Sea to Baja California: Circum-Pacific Council for Energy and Mineral Resources, Earth Science Series v. 6, p. 229-268.

Plafker, George, and Berg, H.C., 1994, Overview of the geology and tectonic evolution of Alaska, chap. 33 of Plafker, George, and Berg, H.C., eds., The geology of Alaska: Boulder, Colo., Geological Society of America, The Geology of North America, v. G-1, p. 989-1021.

Popov, M.A., Nuccio, V.F., Dyman, T.S., Gognat, T.A., Johnson, R.C., Schmoker, J.W., Wilson, M.S., Bartberger, Charles, 2001, Basin centered gas systems of the U.S.: U.S. Geological Survey Open-File Report 2001-135, 506 p., http://pubs.er.usgs.gov/publication/ofr2001135. 
Potter, C.J., and Moore, T.E., 2003, Brookian structural plays in the National Petroleum Reserve, Alaska: U.S. Geological Survey Open-File Report 03-266, 36 p., 13 figs.,

http://pubs.usgs.gov/of/2003/of03-266/.

Reading, H.G., and Richards, Marcus, 1994, Turbidite systems in deep-water basin margins classified by grain size and feeder system: American Association of Petroleum Geologists Bulletin, v. 78, no. 5, p. 792-822.

Richards, B.C., Bamber, E.W., Utting, J., 1997, Upper Devonian to Permian, in Norris, D.K., ed., Geology and mineral and hydrocarbon potential of northern Yukon Territory and Northwestern District of Mackenzie: Ottawa, Canada, Geological Survey of Canada, p. 201-251.

Richards, M., and Bowman, M., 1998, Submarine fans and related depositional systems II—Variability in reservoir architecture and wireline log character: Marine and Petroleum Geology, v. 15, p. 821-839.

Ridgway, K.D., Thoms, E.E., Layer, P.W., Lesh, M.E., White, J.M., and Smith, S.V., 2007, Neogene transpressional foreland basin development on the north side of the central Alaska Range, Usibelli Group and Nenana Gravel, Tanana Basin, in Ridgway, K.D., Trop, J.M., Glen, J.M.G., and O'Neill, J.M., eds., Tectonic growth of a collisional continental margin - Crustal evolution of southern Alaska: Geological Society of America Special Paper 431, p. 507-547.

Roberts, S.B., Stricker, G.D., and Affolter, R.H., 1992, Reevaluation of coal resources in the Late Cretaceous-Tertiary Sagavanirktok Formation, North Slope, Alaska, in Bradley, D.C., and Ford, A.B., eds., Geologic studies in Alaska by the Geological Survey, 1990: U.S. Geological Survey Bulletin, 1999, p. 196-203.

Roeder, Dietrich, and Mull, C.G., 1978, Tectonics of Brooks Range ophiolites, Alaska: American Association of Petroleum Geologists Bulletin, v. 62, p. 1696-1713.

Rowan, E.L., Stanley, R.G., 2008, The Yukon Flats Cretaceous(?)-Tertiary extensional basin, eastcentral Alaska-Burial and thermal history modeling: U.S. Geological Survey Scientific Investigations Report 2007-5281, 12 p., http://pubs.usgs.gov/sir/2007/5281.

Saltus, R.W., and Bird, K.J., 2003, Digital depth horizon compilations of the Alaskan North Slope and adjacent arctic regions: U.S. Geological Survey Open-File Report 03-230, 21 p.

Saltus, R.W., Kulander, C.S., and Potter, C.J., 2002, Digital recovery, modification, and analysis of Tetra Tech seismic horizon mapping, National Petroleum Reserve Alaska (NPRA), northern Alaska: U.S. Geological Survey Open-File Report 02-0111, 12 p., 2 figs., 4 tables, http://pubs.usgs.gov/of/2002/ofr-02-111/.

Schenk, C.J., and Houseknecht, D.W., 2008, Geologic model for oil and gas assessment of the KemikThomson play, central North Slope, Alaska: U.S. Geological Survey Scientific Investigations Report 2008-5146, $28 \mathrm{p}$.

Sixsmith, P.J., Hampson, G.J., Gupta, Sanjeev, Johnson, H.D., and Fofana, J.F., 2008, Facies architecture of a net transgressive sandstone reservoir analog-The Cretaceous Hosta Tongue, New Mexico: American Association of Petroleum Geologists Bulletin, v. 92, no. 4, p. 513-547.

Smosna, Richard, 1989, Compaction law for Cretaceous sandstones of Alaska's North Slope: Journal of Sedimentary Petrology, v. 59, p. 572-584.

Stanley, R.G., Flores, R.M., and Wiley, T.J., 1992, Fluvial facies architecture in the Tertiary Usibelli Group of Suntrana, central Alaska, in Bradley, D.C., and Ford, A.B., eds., Geologic studies in Alaska by the U.S. Geological Survey, 1990: U.S. Geological Survey Bulletin 1999, p. 204-211.

Stanley, R.G., Ahlbrandt, T.S., Charpentier, R.R., Cook, T.A., Crews, J.M., Klett, T.R., Lillis, P.G., Morin, R.L., Phillips, J.D., Pollastro, R.M., Rowan, E.L., Saltus, R.W., Schenk, C.J., Simpson, M.K., Till, A.B., Troutman, S.M., and Hendley, J.W., II, eds., 2004, National assessment of oil and gas fact sheet-Oil and gas assessment of Yukon Flats, east-central Alaska, 2004: U.S. Geological Survey Fact Sheet 2004-3121, 2 p., http://pubs.usgs.gov/fs/2004/3121/. 
Stephenson, W.J., Williams, R.A., Odum, J.K., Barker, C.E., Worley, D.M., Clark, A.C., and Clough, J.G., 2002, Reconnaissance shallow seismic investigation of depth-to-bedrock and possible methanebearing coalbeds, Galena, Alaska: U.S. Geological Survey Open-File Report 02-450, 36 p.

Umekwe, Pascal, Mongrain, Joanna, Ahmadi, Mohabbat, and Hanks, Catherine, 2012, Assessment of Alaska's North Slope oil field capacity to sequester $\mathrm{CO}_{2}$ : Natural Resources Research, v. 22, no. 1, p. 45-58.

Underwood, M.B., Laughland, M.M., Wiley, T.J., and Howell, D.G., 1989, Thermal maturity and organic geochemistry of the Kandik Basin region, east-central Alaska: U.S. Geological Survey OpenFile Report 89-353, 41 p., http://pubs.usgs.gov/of/1989/0353/report.pdf.

U.S. Environmental Protection Agency, 2009, Safe Drinking Water Act (SDWA): Washington, D.C., U.S. Environmental Protection Agency Web site, accessed January 14, 2009, at http://www.epa.gov/ogwdw/sdwa/index.html.

U.S. Environmental Protection Agency, 2010, Federal requirements under the underground injection control (UIC) for carbon dioxide $\left(\mathrm{CO}_{2}\right)$ geologic sequestration (GS) wells: Washington, D.C., U.S. Environmental Protection Agency Web site, accessed October 15, 2012, at http://water.epa.gov/type/groundwater/uic/class6/gsregulations.cfm.

Van Kooten, G.K., Watts, A.B., Coogan, James, Mount, V.S., Swenson, R.F., Daggett, P.H., Clough, J.G., Roberts, C.T., and Bergman, S.C., 1997, Gravity maps of the Kandik area, Alaska, and adjacent Yukon Territory, Canada: Alaska Division of Geological \& Geophysical Surveys Report of Investigation 96-6C, 1 sheet, scale 1:250,000.

Van Kooten, G.K., Richter, M., and Zippi, P.A., 2012, Alaska's interior rift basins-A new frontier for discovery: Oil and Gas Journal, v. 110, no. 1a.

Wartes, M.A., Decker, P.L., Gillis, R.J., 2011, Improving the nomenclature of the Brookian depositional system in northern Alaska-The role of sequence stratigraphy: American Association of Petroleum Geology Pacific Section Meeting, Anchorage, Alaska, p. 8-11.

Weatherford, 2009, Wireline services log interpretation chart book: Houston, Texas, Weatherford, $206 \mathrm{p}$.

Wesson, R.L., Boyd, O.S., Mueller, C.S., Bufe, C.G., Frankel, A.D., Petersen, M.D., 2007, Revision of time-independent probabilistic seismic hazard maps for Alaska: U.S. Geological Survey Open-File Report 2007-1043, 33 p.

Wicks, J.L., Buckingham, M.L., and Dupree, J.H., 1991, Endicott field-U.S.A., North Slope Basin, Alaska, in Foster N.H., and Beaumont, E.A., eds., Structural traps V: American Association of Petroleum Geology Treatise of Petroleum Geology, Atlas of Oil and Gas Fields, p. 1-25.

Wilson, F.H., Detterman, R.L., and DuBois, G.D., 1999, Digital data for geologic framework of the Alaska Peninsula, southwest Alaska, and the Alaska Peninsula terrane: U.S. Geological Survey OpenFile Report 99-317, http://wrgis.wr.usgs.gov/open-file/of99-317/aptext.pdf.

Wilson, G.C., Burns, B.A., McGowen, J.H., Tye, R.S., and Veldhuis, J.H., 2001, Lithofacies and depositional environments of the Permo-Triassic Sadlerochit Group in the National Petroleum Reserve-Alaska (NPRA), in Houseknecht, D.W., ed., NPRA core workshop-Petroleum plays and systems in the National Petroleum Reserve-Alaska (NPRA): SEPM Core Workshop No. 21, 230 p. Wirth, K.R., Bird, J.M., Blythe, A.E., and Harding, D.J., 1993, Age and evolution of western Brooks Range ophiolites, Alaska-Results from ${ }^{40} \mathrm{Ar} /{ }^{39} \mathrm{Ar}$ thermochronology: Tectonics, v. 12, p. 410-432. Wood, G.V., and Armstrong, A.K., 1975, Diagenesis and stratigraphy of the Lisburne Group limestones of the Sadlerochit Mountains and adjacent areas, northeastern Alaska: U.S. Geological Survey Professional Paper 857, 80 p. 